
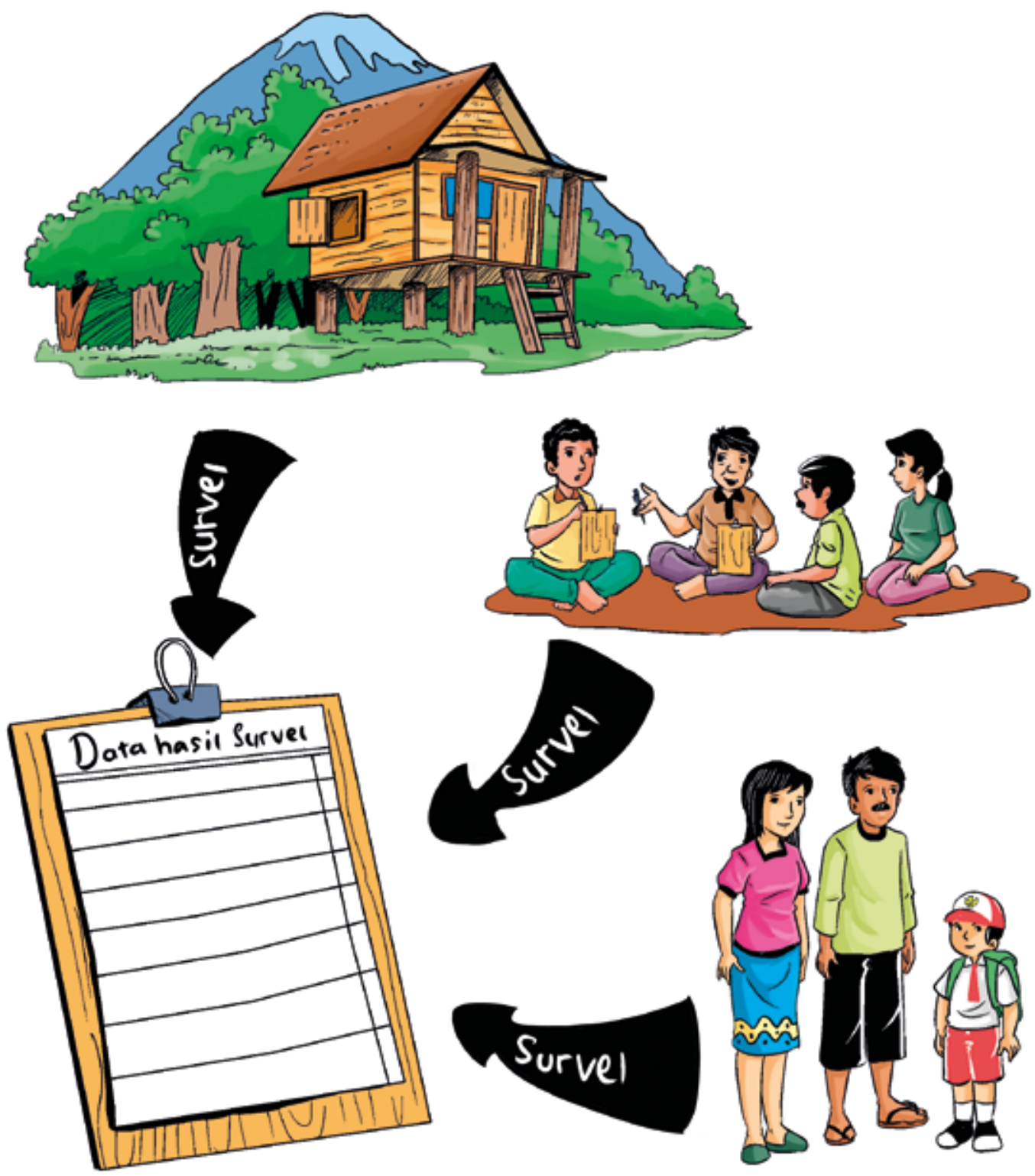

Panduan praktis untuk survei mata pencaharian sosial-ekonomi dan hak dan kepemilikan lahan untuk digunakan dalam perencanaan penggunaan lahan kolaboratif yang berbasis ekosistem

Nining Liswanti, Bayuni Shantiko, Emily Fripp, Esther Mwangi dan Yves Laumonier

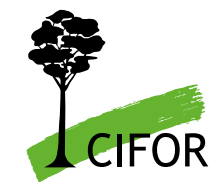





\title{
Panduan praktis untuk survei mata pencaharian sosial-ekonomi dan hak dan kepemilikan lahan untuk digunakan dalam perencanaan penggunaan lahan kolaboratif yang berbasis ekosistem
}

\author{
Nining Liswanti \\ CIFOR \\ Bayuni Shantiko \\ CIFOR \\ Emily Fripp \\ EFECA \\ Esther Mwangi \\ CIFOR \\ Yves Laumonier \\ CIRAD-CIFOR
}


๑) 2012 Center for International Forestry Research

Hak cipta dilindungi oleh undang-undang

ISBN 978-602-8693-91-2

Liswanti, N., Shantiko, B., Fripp, E., Mwangi, E. dan Laumonier, Y. 2012 Panduan praktis untuk survei mata pencaharian sosial-ekonomi dan hak dan kepemilikan lahan untuk digunakan dalam perencanaan penggunaan lahan kolaboratif yang berbasis ekosistem. CIFOR, Bogor, Indonesia.

Diterjemahkan dari: Liswanti, N., Shantiko, B., Fripp, E., Mwangi, E. and Laumonier, Y. 2012 Practical guide for socio-economic livelihood, land tenure and rights surveys for use in collaborative ecosystem-based land use planning. CIFOR, Bogor, Indonesia.

Ilustrasi oleh Pandu Dharma Wijaya (TELAPAK)

CIFOR

Jl. CIFOR, Situ Gede

Bogor Barat 16115

Indonesia

$\mathrm{T}+62(251) 8622-622$

$\mathrm{F}+62(251) 8622-100$

E cifor@cgiar.org

\section{cifor.org}

Semua pendapat yang dinyatakan dalam publikasi ini berasal dari para penulis dan tidak serta merta mencerminkan pendapat CIFOR, lembaga tempat bernaung penulis atau penyandang dana publikasi ini. 


\section{Daftar isi}

Bagian A: Pendekatan

Tujuan dari panduan 1

Apakah perencanaan penggunaan lahan kolaboratif itu? 2

Bagian B: Melaksanakan survei sosial-ekonomi 5

Tahap 1 - Desain survei, pengambilan sampel dan data yang dibutuhkan 5

Tahap 2 - Perencanaan dan pelatihan tim 8

Tahap 3 - Pelaksanaan 8

Bagian C: Menggunakan data yang dikoleksi 13

Tahap 1 - Analisis data 14

Tahap 2 - Menggunakan hasil 15

$\begin{array}{ll}\text { Catatan Pendukung } 1 \text { sampai } 9 & 17\end{array}$

Catatan 1 - Definisi kunci 18

Catatan 2 - Teknik penarikan sampel $\quad 20$

Catatan 3-Memilih pertanyaan yang tepat 23

Catatan 4-Melaksanakan survei 27

Catatan 5-Panduan pertemuan dengan masyarakat 29

Catatan 6-Teknik wawancara 31

Catatan 7 - Diskusi kelompok terfokus 33

Catatan 8 - Contoh kuesioner baku: Rumah tangga, desa, dan informan kunci 38

$\begin{array}{ll}\text { Catatan } 9 \text { - Pengalaman dari proyek CoLUPSIA } & 87\end{array}$

$\begin{array}{ll}\text { Rujukan } & 93\end{array}$

Situs web $\quad 94$ 


\section{Daftar gambar, tabel dan kotak}

\section{Gambar}

1 Mengembangkan dan melaksanakan survei

2 Desa-desa penelitian di empat lokasi pilot di Kapuas Hulu, Kalimantan Barat

3 Desa-desa penelitian di lima lokasi pilot di Maluku Tengah (Pulau Seram), Maluku

\section{Tabel}

1 Keunggulan dan kelemahan pertanyaan terbuka 24

2 Keunggulan dan kelemahan pertanyaan semiterbuka 25

3 Keunggulan dan kelemahan pertanyaan tertutup 26

4 Contoh tema dan topik untuk bahan diskusi dalam FGD 34

5 Data sosial-ekonomi yang dibutuhkan untuk kolaboratif perencanaan penggunaan lahan

\section{Kotak}

1 Contoh catatan penjelasan untuk mengenalkan anggota tim survei di desa 30

2 Panduan wawancara

3 Peran fasilitator 


\section{Bagian A: Pendekatan}

Memahami kondisi sosial-ekonomi, kepemilikan lahan dan hak-hak masyarakat merupakan aspek penting dari perencanaan penggunaan lahan kolaboratif.

\section{Tujuan dari panduan}

Panduan ini bertujuan untuk memberikan langkah-langkah praktis bagi para praktisi di lapangan dalam melakukan survei sosial-ekonomi rumah tangga dan desa, termasuk diskusi kelompok terfokus dan wawancara informan kunci. Panduan ini disertai sembilan Catatan Pendukung, yang merupakan alat penting untuk mengumpulkan informasi sosial-ekonomi. Hasil informasi yang dikumpulkan dapat digunakan sebagai masukan untuk mengembangkan prosedur dan alat pengambilan keputusan tentang penggunaan lahan kolaboratif.

Alat survei sosial-ekonomi dirancang untuk mengumpulkan informasi sebagai sarana meningkatkan pemahaman tentang sistem pengelolaan sumberdaya lokal, penggunaan sumberdaya dan kepentingan relatif masing-masing untuk rumah tangga dan desa. Survei juga memberikan informasi tentang interaksi antara sistem pengambilan keputusan oleh pemerintah dan tren persepsi masyarakat dan isu-isu prioritas. Pengetahuan tentang lembaga berbasis masyarakat, yang juga

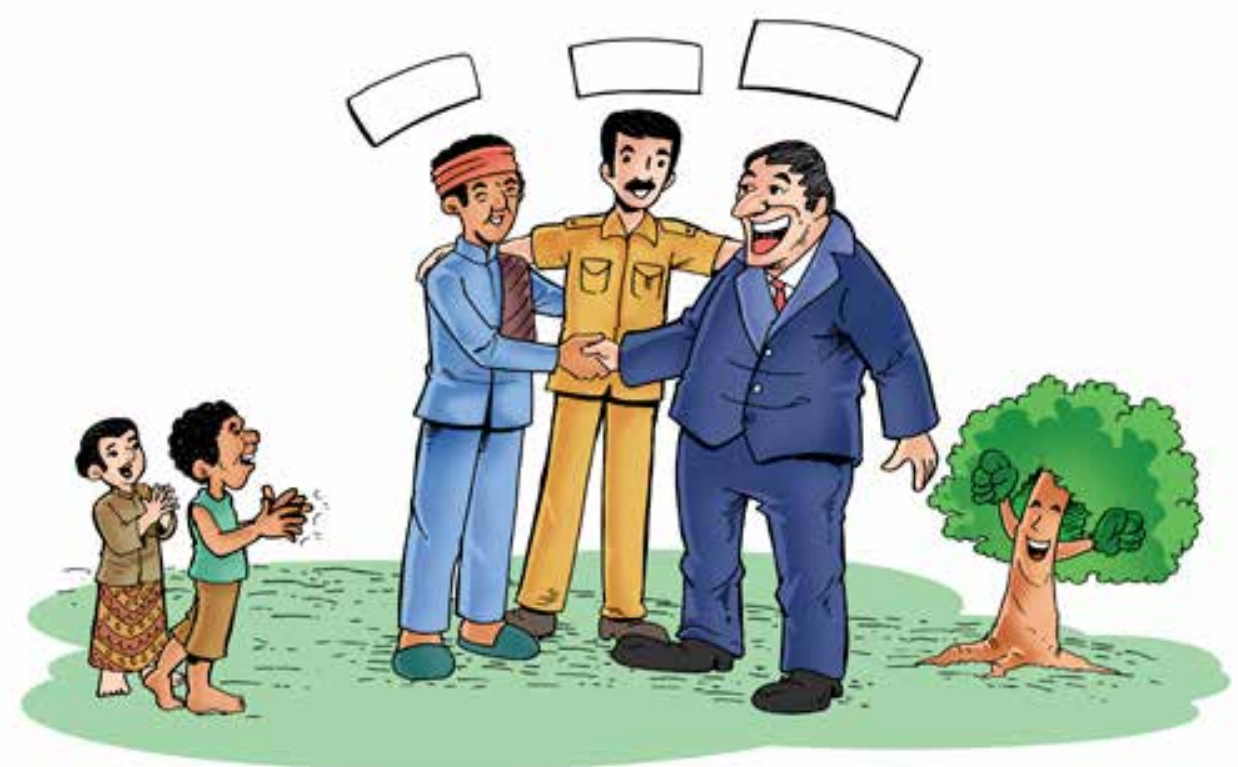


diperoleh melalui survei, dan peran mereka dalam pemanfaatan berkelanjutan dan konservasi sumberdaya alam, membantu untuk melancarkan atau memperkuat konsensus tentang kepemilikan lahan dan hak-hak di daerah, sekarang dan di masa depan. Dengan demikian, survei juga berfungsi untuk menyoroti peluang yang memungkinkan untuk resolusi konflik antara para pemangku kepentingan. Konflik atas sumberdaya sering muncul akibat ketidakjelasan batas dan respek terhadap pengaturan kelembagaan untuk lahan.

\section{Apakah perencanaan penggunaan lahan kolaboratif itu?}

Perencanaan penggunaan lahan kolaboratif melibatkan kerja sama dengan semua pemangku kepentingan - pemerintah, masyarakat lokal, sektor swasta dan individu lain yang relevan - untuk memastikan bahwa lahan digunakan secara berkelanjutan, menghindari dampak negatif atau ancaman dari degradasi lingkungan dan hilangnya hutan sambil memastikan bahwa pertimbangan sosial dan ekonomi dari semua pengguna dipertimbangkan. Dalam kaitan khususnya dengan masyarakat, tujuan perencanaan penggunaan lahan kolaboratif adalah sebagai berikut:

Untuk memastikan bahwa keputusan perencanaan penggunaan lahan diambil dengan mempertimbangkan pendapat masyarakat lokal, kebutuhan penggunaan lahan dan kondisi sosial-ekonomi (peluang dan kendala), termasuk hak akses ke lahan dan untuk menggunakannya

Langkah pertama dalam proses ini adalah melibatkan masyarakat lokal. Hal ini dapat dicapai melalui penggunaan survei rumah tangga dan desa, dan diskusi kelompok terfokus. Langkah ini merupakan cara penting positif yang melibatkan para pemangku kepentingan lokal dalam proses perencanaan dan untuk memastikan bahwa suara-suara lokal didengar.

Survei dan diskusi kelompok terfokus juga menyediakan cara untuk mendapatkan pemahaman menyeluruh tentang hubungan masyarakat lokal dengan sumberdaya yang relevan - ekonomi dan sosial - dan hak hukum mereka serta akses untuk menggunakan sumberdaya. Informasi ini sangat penting untuk perencanaan penggunaan lahan yang efektif, yaitu perencanaan yang akan dapat diterapkan secara praktis dan yang memenuhi kebutuhan lokal, sehingga berpotensi menghindari konflik atas sumberdaya di antara pihak-pihak yang berkepentingan. Istilah-istilah kunci didefinisikan dalam Catatan Pendukung 1. 


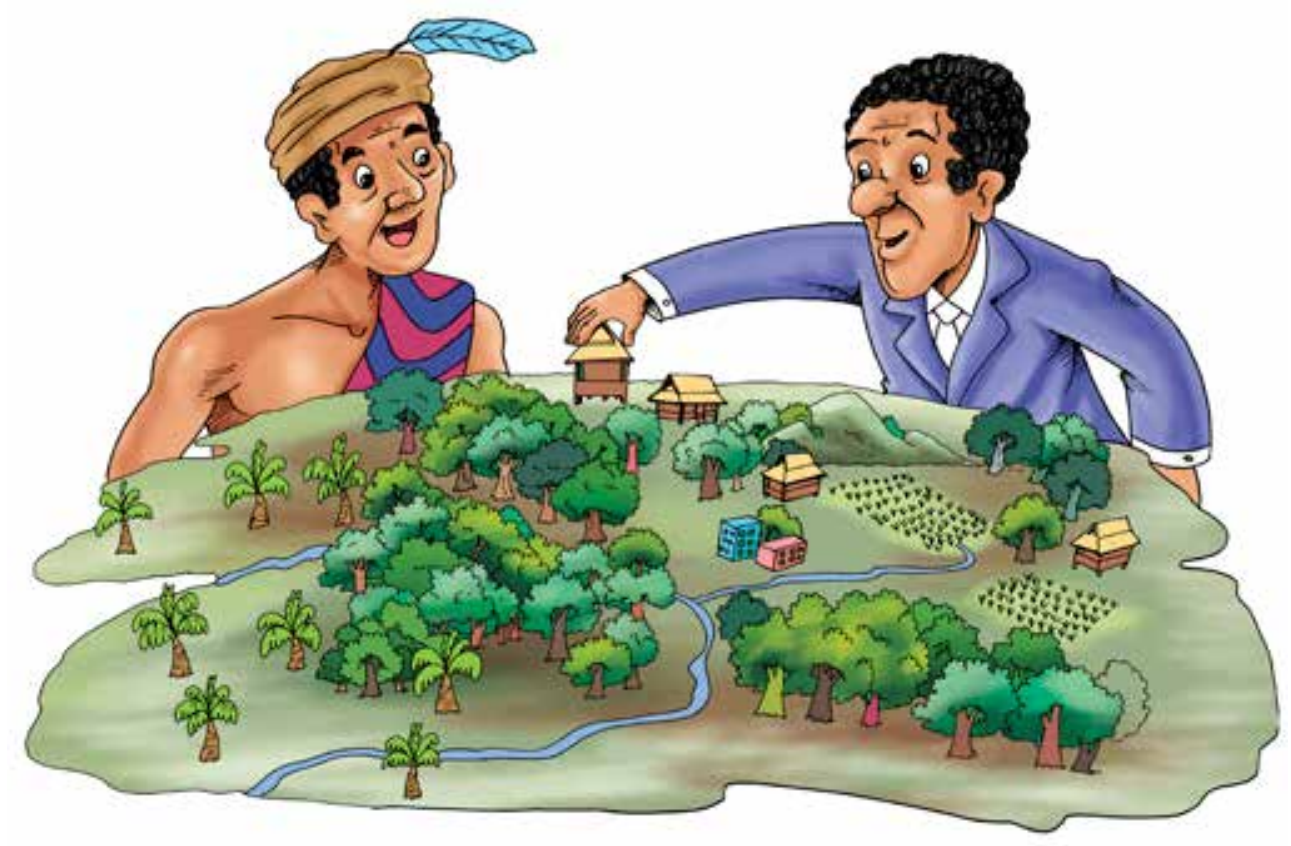





\section{Bagian B: Melaksanakan survei sosial-ekonomi}

Melakukan survei rumah tangga dan desa dan diskusi kelompok terfokus untuk memahami mata pencaharian dan hak dan kepemilikan lahan
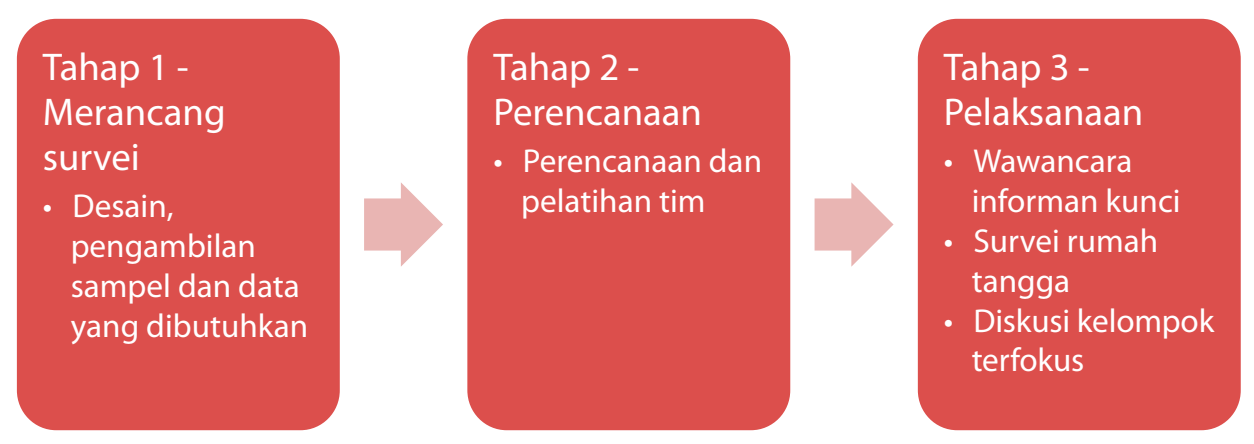

Gambar 1. Mengembangkan dan melaksanakan survei

\section{Tahap 1 - Desain survei, pengambilan sampel dan data yang dibutuhkan}

Ketika melakukan survei, langkah pertama adalah menentukan maksud dan tujuan survei. Langkah ini menjelaskan kerangka kerja survei, termasuk muatan dan cakupan pekerjaan survei dan juga digunakan untuk membantu mengidentifikasi jenis pemangku kepentingan dan masyarakat yang harus disurvei.

\section{Data yang dibutuhkan dan desain survei}

Data yang akan dikumpulkan melalui proses survei harus mencerminkan tujuan survei. Dalam mengembangkan survei, pertimbangan lainnya adalah lamanya waktu wawancara dan kebutuhan sumberdaya (keuangan, manusia) yang efektif melakukan survei, memasukkan data dan menganalisis hasilnya.

Alat yang berbeda (survei, diskusi, wawancara) digunakan untuk mendapatkan berbagai jenis informasi dari berbagai kelompok informan. Misalnya, survei rumah tangga dapat digunakan untuk mengumpulkan informasi tentang umur, jenis kelamin, pendidikan, sumber pendapatan (pertanian, kehutanan dan 


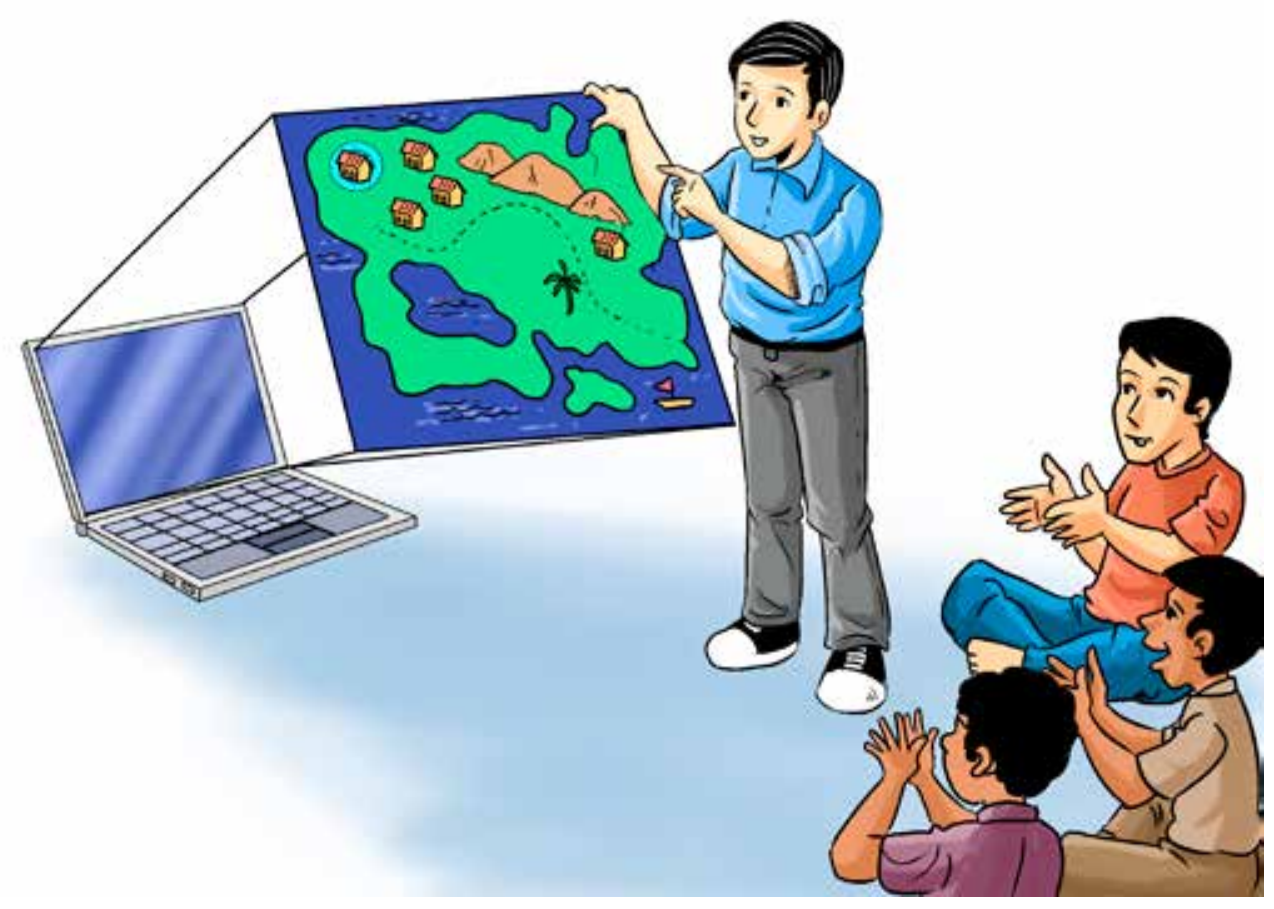

lapangan kerja lainnya), dan persepsi tentang perubahan penggunaan lahan dan akses ke sumberdaya hutan. Sebaliknya, pemahaman fungsi (pemerintahan dan kelembagaan) desa, pembangunan, isu-isu yang lebih luas tentang akses lahan, pertumbuhan penduduk, kondisi sosial dan kendala dapat diperoleh melalui diskusi kelompok terfokus dan wawancara dengan informan kunci. Metode survei dijelaskan dalam Langkah 3.

\section{Siapa yang perlu dilibatkan dalam survei?}

Individu-individu dan masyarakat yang akan disurvei harus diputuskan saat mempertimbangkan maksud dan tujuan survei. Individu atau kelompok individu yang berbeda akan diwawancarai sesuai dengan data yang diperlukan. Untuk survei rumah tangga yang diwawancarai adalah kepala rumah tangga, namun dalam sebuah wawancara informan kunci maka yang diwawancarai adalah kepala desa atau kepala adat. Diskusi kelompok terfokus akan melibatkan anggota masyarakat, dengan kelompok-kelompok yang dibagi berdasarkan usia dan jenis kelamin yang berbeda. 


\section{Pengambilan sampel acak dan ukuran sampel}

Ukuran sampel harus cukup untuk memastikan bahwa hasil survei secara statistik akan relevan. Namun, ukuran sampel umumnya juga harus diimbangi sumberdaya yang tersedia - keuangan, manusia dan waktu.

Pengambilan sampel acak digunakan untuk memastikan agar sampel yang dipilih mewakili daerah penelitian, menghindari hasil yang bias dan memastikan bahwa semua elemen dari suatu populasi memiliki kesempatan yang sama untuk diwawancarai. Ada beberapa pendekatan dalam menentukan sampel acak, misalnya sistematis, bertingkat dan cluster. Dalam kaitannya dengan perencanaan penggunaan lahan kolaboratif, pendekatan sampel acak sederhana sudah memadai (Catatan Pendukung 2).

\section{Jenis pertanyaan}

Untuk semua jenis wawancara (untuk rumah tangga, diskusi kelompok terfokus dan informan kunci), pertanyaannya dapat terstruktur dan ditanyakan sebagai pertanyaan terbuka, tertutup atau semiterbuka. Jenis pertanyaan yang digunakan bergantung pada informasi yang sedang dikumpulkan. Setiap jenis pertanyaan ini ada keuntungan dan kerugiannya (Catatan Pendukung 3).

Melalui pertanyaan terbuka, contohnya 'Mengapa panen padi menurun tahun ini?”, pewawancara dapat mengungkap makna di balik jawaban, yang memungkinkan responden memberikan contoh dan menjelaskan jawaban mereka. Pertanyaan-pertanyaan ini lebih memakan waktu untuk dikelola dan dianalisis. Pertanyaan terbuka bisa sulit untuk ditanyakan dan untuk menafsirkan responnya, sehingga diperlukan pelatihan untuk melakukannya.

Suatu pertanyaan semiterbuka sebagian, contohnya 'Konsumsi produk hutan meningkat, karena...' membutuhkan responden untuk menguraikan setiap jawaban yang diberikan. Keuntungan dari pertanyaan ini adalah mereka lebih cepat dan lebih mudah ditanyakan dan di analisis daripada pertanyaan terbuka, tetapi si pewawancara mungkin kehilangan beberapa informasi karena kurangnya kategori yang sesuai atau tingkat jawaban responden yang lebih rinci. Untuk menghindari masalah ini, jawaban responden harus dicatat secara penuh, dan si pewawancara harus mengulang pertanyaan apakah jawaban responden masih kurang lengkap. 
Pertanyaan tertutup, seperti pilihan ganda atau ya/tidak ada jawaban, digunakan ketika informasi kunci yang diperlukan bisa diperoleh tanpa perlu penjelasan lebih lanjut atau pemahaman mendalam tentang jawaban atau masalahnya. Pertanyaanpertanyaan seperti ini dapat ditanyakan dan dianalisis dengan cepat, namun hasil jawabannya dapat menjadi kurang dalam dan jelas.

\section{Tahap 2 - Perencanaan dan pelatihan tim}

Sebuah tim yang terlatih dan berpengalaman sangat penting bagi keberhasilan setiap survei sosial-ekonomi. Pengalaman praktis sebelumnya adalah aset besar untuk tim, misalnya dengan pengetahuan teknis yang relevan di bidang sosialekonomi, kehutanan dan sumberdaya alam.

Semua anggota tim membutuhkan pelatihan secara lengkap dan rinci untuk semua jenis survei (rumah tangga, desa, diskusi kelompok terfokus, wawancara informan kunci) yang akan dilakukan. Semua anggota tim harus memiliki pemahaman yang menyeluruh tentang tujuan kegiatan dan makna setiap pertanyaan yang akan ditanyakan. Kombinasi pelatihan di kelas dan di lapangan akan memberikan pemahaman terbaik tentang prosedur dan metode survei. Selain itu, pelatihan lapangan sangat berguna untuk memeriksa pertanyaan survei dan maksud pengumpulan data, sehingga memberikan kesempatan untuk melakukan revisi yang diperlukan untuk survei, pertanyaan wawancara dan prosedur surveinya.

Pembagian tugas antara anggota tim juga perlu dipertimbangkan - fasilitator, manajer sumberdaya, pengamat/perekam, dan pemimpin tim.

Melalui persiapan yang matang (merancang pekerjaan survei, melatih tim, dll) dan penjadualan pekerjaan survei sangat penting untuk keberhasilan survei (Catatan Pendukung 4). Persiapan tim survei dan kesepakatan rencana kerja dan kerangka waktu untuk menyelesaikan survei harus ditetapkan lebih dahulu. Desa yang akan disurvei juga harus diberitahu terlebih dahulu sebelumnya dan izin untuk melakukan wawancara harus diperoleh dan dipastikan.

\section{Tahap 3 - Pelaksanaan}

Pendekatan survei bervariasi. Pendekatan yang berbeda digunakan untuk tujuan yang berbeda. Untuk perencanaan penggunaan lahan kolaboratif, digunakan tiga metode survei, yaitu:

- Wawancara informan kunci,

- Survei rumah tangga, dan

- Diskusi kelompok terfokus 

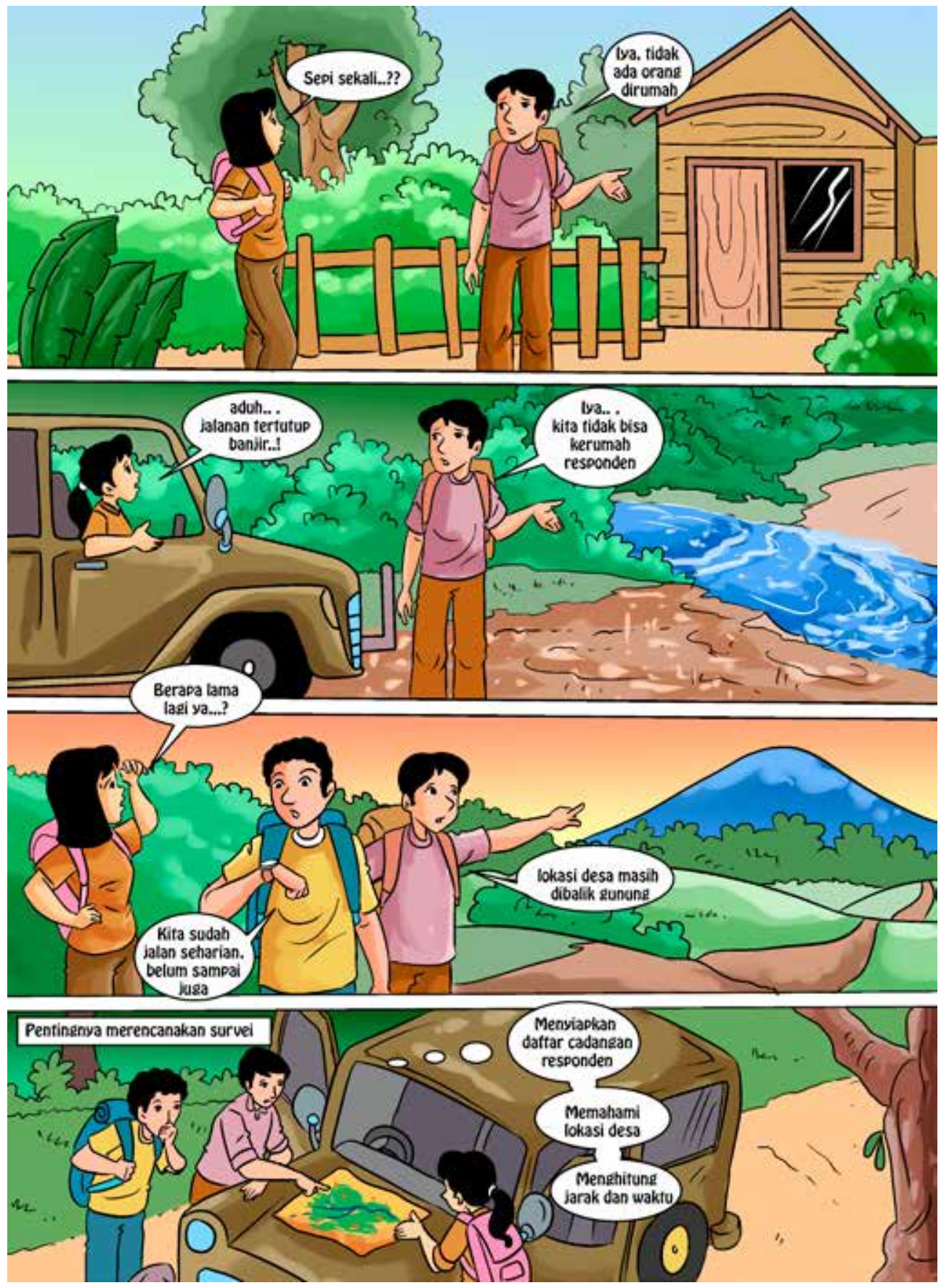

Sebelum memulai setiap pekerjaan survei, sebaiknya dilakukan pertemuan dengan masyarakat. 


\section{Pertemuan dengan masyarakat}

Pertemuan dengan masyarakat merupakan cara yang berharga dan produktif bagi tim survei untuk bertemu dengan penduduk desa, menjelaskan pekerjaan survei tujuan dan pendekatan - dan memastikan bahwa semua anggota masyarakat memahami hasil yang diharapkan dari survei (Catatan Pendukung 5). Keputusan melakukan pertemuan masyarakat harus diambil setelah bertemu dengan kepala masyarakat atau desa. Jika memungkinkan, kepala desa bisa membantu mengatur dan melakukan pertemuan dengan masyarakat.

\section{Wawancara informan kunci}

Informan kunci adalah orang-orang yang dianggap memiliki pengetahuan tentang isu-isu tertentu. Informan kunci akan memberikan informasi rinci kepada tim wawancara, dan terutama dalam menafsirkan sejumlah isu penting yang tidak bisa diberikan oleh anggota masyarakat lainnya. Informan kunci yang potensial harus dipilih, melalui konsultasi dengan kepala desa, pemimpin tradisional atau kepala marga, untuk diwawancarai secara mendalam oleh tim survei (Catatan Pendukung 6).

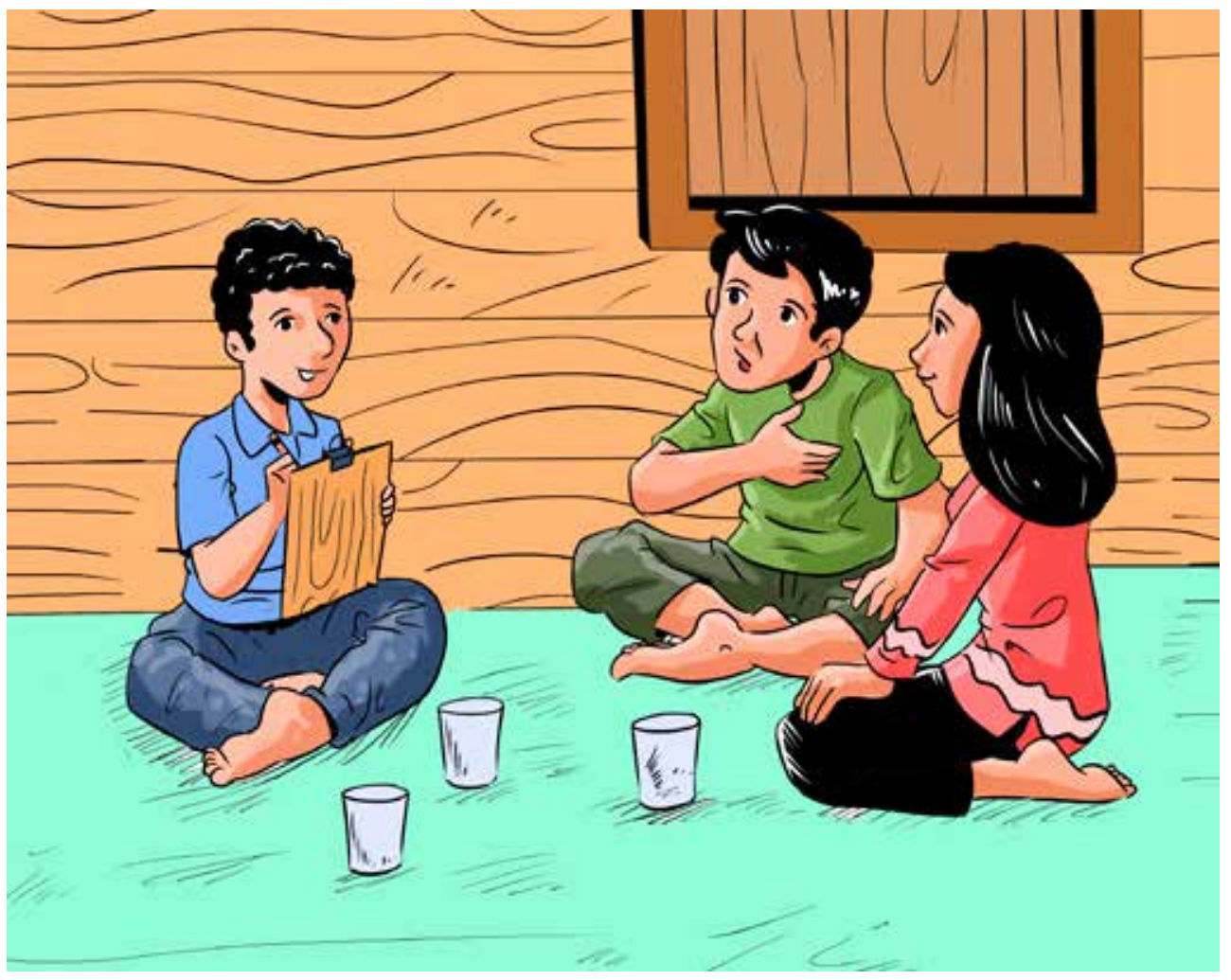




\section{Survei desa dan rumah tangga}

Survei desa dan rumah tangga terutama digunakan untuk mengumpulkan data kuantitatif dan kualitatif, melalui wawancara terstruktur dengan kepala rumah tangga. Jenis pertanyaan yang digunakan bisa berupa pertanyaan tertutup dan terbuka. Formulir survei, baik untuk tingkat rumah tangga maupun desa, dirancang untuk mendapatkan informasi yang spesifik, relevan dengan tujuan survei, seperti yang dibahas di atas.

\section{Diskusi kelompok terfokus}

Diskusi kelompok terfokus ini bertujuan untuk memperoleh informasi mendalam tentang konsep, persepsi dan gagasan sekelompok orang berjumlah 6-12 orang. Idealnya, diskusi ini adalah suatu proses yang berulang-ulang, dimana setiap diskusi didasarkan pada diskusi sebelumnya dengan mengembangkan suatu topik atau penekanan pada aspek-aspek tertentu (Catatan Pendukung 7).

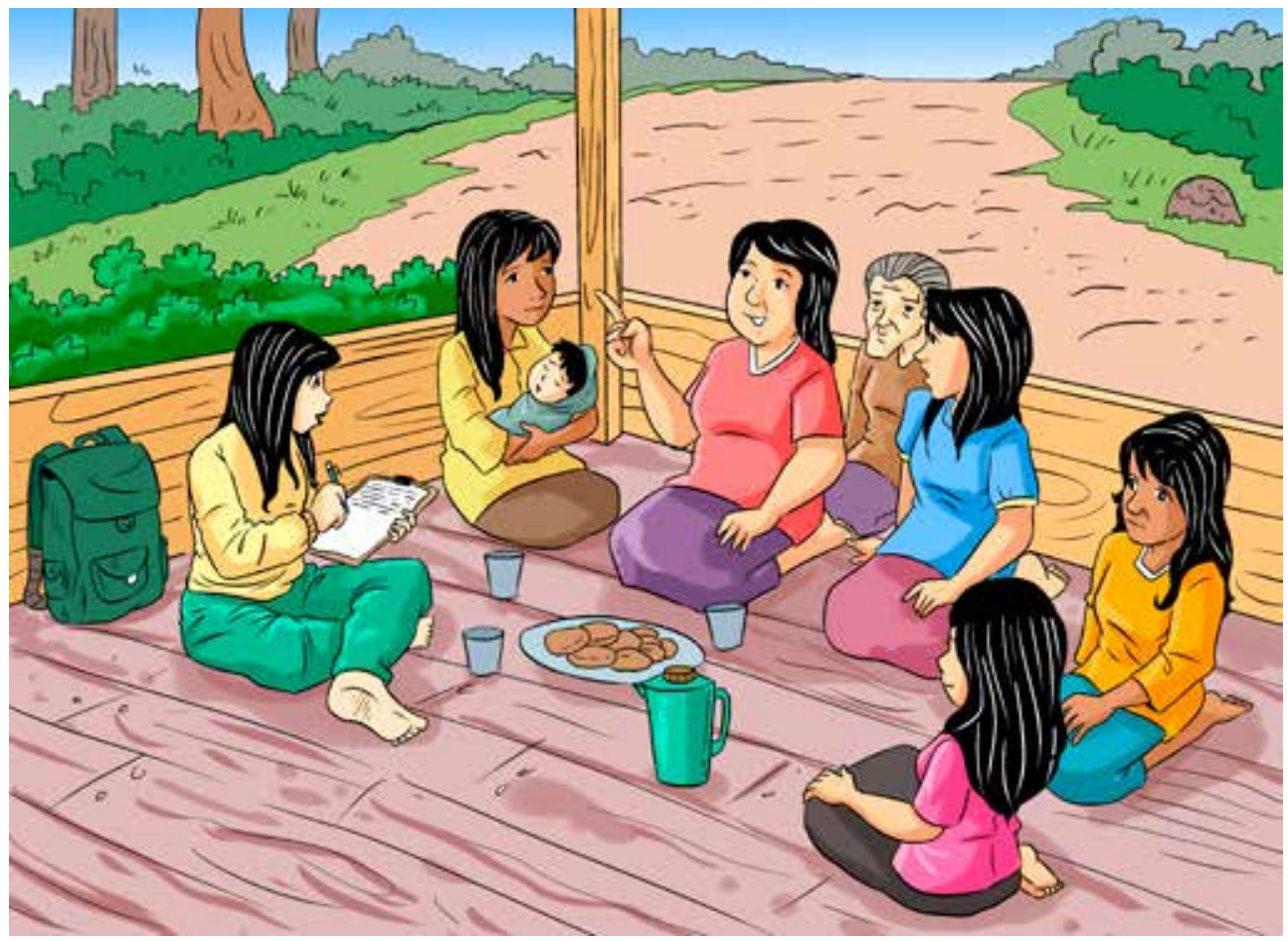


Dalam konteks perencanaan penggunaan lahan kolaboratif, diskusi kelompok terfokus mencakup diskusi tentang pengaturan kelembagaan, hak-hak masyarakat, akses masyarakat terhadap hutan, penggunaan hutan oleh masyarakat dan pengelolaan sumberdaya hutan secara berkelanjutan,

Kunci keberhasilan diskusi kelompok terfokus adalah adanya fasilitator yang kuat yang akan merangsang diskusi dan memastikan bahwa proses diskusi telah sesuai dengan sasaran yang ingin dicapai tim survei.

Cara ini bermanfaat jika instrumen penelitian lain yang digunakan berhubungan dengan diskusi kelompok terfokus, seperti wawancara informan kunci, wawancara mendalam atau teknik kualitatif lainnya.

Formulir survei yang digunakan untuk survei desa dan rumah tangga, wawancara informan kunci dan diskusi kelompok terfokus dapat dilihat dalam Catatan Pendukung 8 . 


\section{Bagian C: Menggunakan data yang dikoleksi}

Analisis dan penggunaan data yang dikoleksi harus mencerminkan tujuan survei

Tingkat analisis dan penggunaan data yang dikumpulkan akan bergantung pada tujuan survei dan hasil akhir yang diharapkan. Untuk perencanaan penggunaan lahan kolaboratif, hasil survei akan menyediakan: Pertama, dasar yang kuat dari faktor sosial-ekonomi yang berhubungan dengan sumberdaya lahan dan kegunaannya, dan kedua, adanya wawasan yang mendalam dan terinci mengenai kelembagaan masyarakat, hubungan mereka dengan para perencana penggunaan lahan (misalnya, badan-badan pemerintah ) dan setiap jenis penggunaan yang berpotensi konflik. Bersama-sama, informasi ini dapat digunakan untuk mengembangkan alat pengambilan keputusan tentang penggunaan lahan kolaboratif.

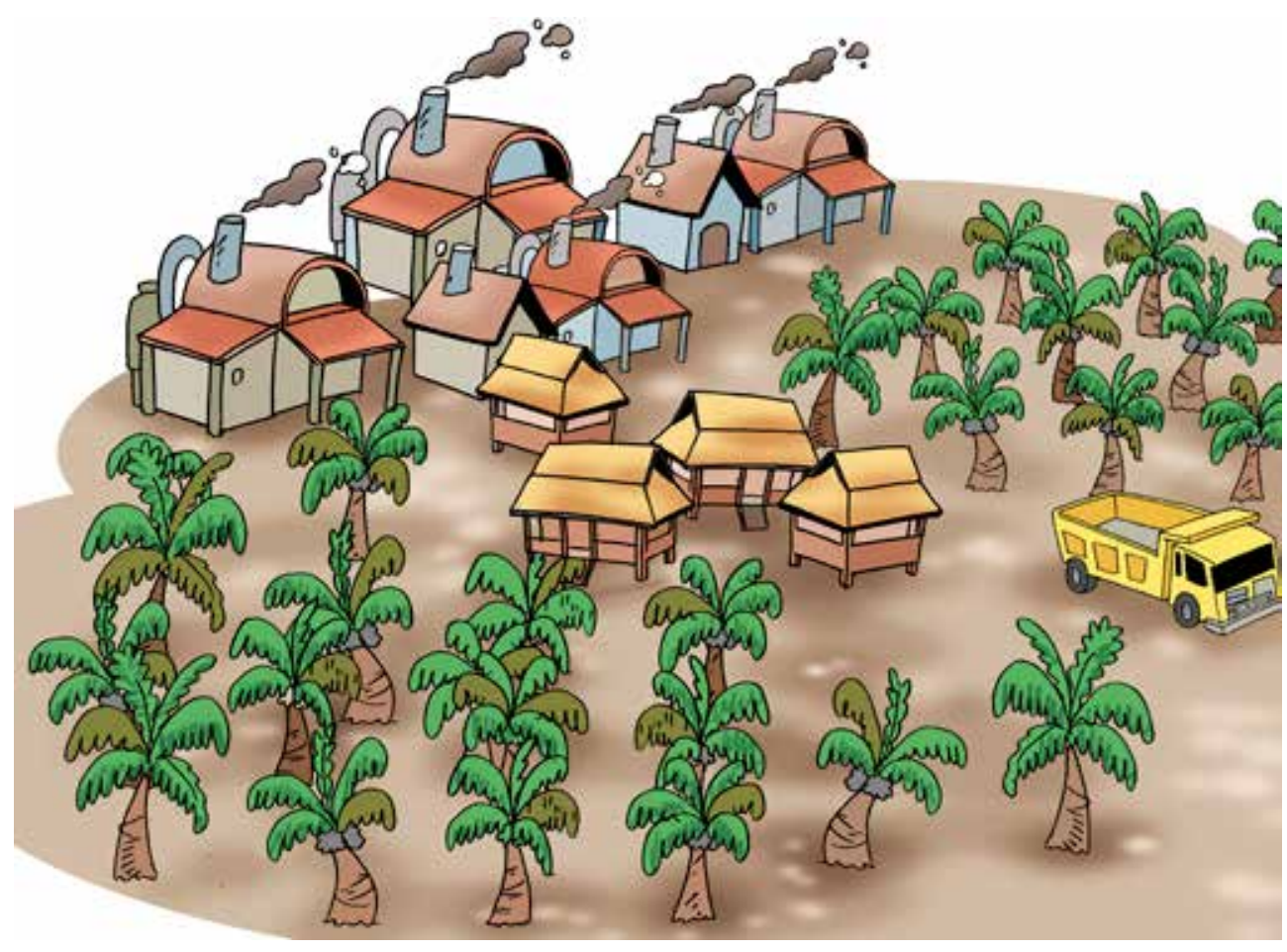




\section{Tahap 1 - Analisis data}

Pemilihan metode untuk analisis data bergantung pada volume data yang dikumpulkan dan penggunaan hasil-hasil temuan yang diharapkan.

Ketika survei tingkat desa dan rumah tangga dilakukan, volume data yang dikumpulkan akan sangat banyak. Analisis data ini biasanya dilakukan dalam satu paket statistik seperti SPSS. Sebelum menggunakan paket perangkat lunak ini, data harus dimasukkan dan dibersihkan sebelum dianalisis. Selanjutnya, data dapat diekspor ke paket perangkat lunak lain seperti Microsoft Excel untuk analisis lebih lanjut dan untuk membuat tabel dan grafik.

Untuk informasi kualitatif lain yang dikumpulkan, misalnya, dari diskusi kelompok terfokus dan wawancara informan kunci, analisis data didasarkan pada metode Grounded Theory yang dikembangkan oleh Glaser dan Strauss. Metode analisis ini memilah daftar kategori di dalam masing-masing pertanyaan penelitian dan berbagai bagian dari instrumen survei untuk mengidentifikasi tema-tema utama secara terpisah untuk diskusi kelompok terfokus dan wawancara informan kunci. Hasilnya diolah menggunakan $n$ Vivo, yaitu perangkat lunak untuk menganalisis data kualitatif. Sebuah skema hierarki pengelompokan tema (kode) dikembangkan atas dasar daftar awal kategori, untuk mencerminkan pertanyaan utama penelitian, dan yang dikembangkan lebih lanjut dengan tema yang muncul dari data. Data tersebut kemudian dianalisis sesuai dengan tema yang telah teridentifikasi.

Untuk diskusi kelompok terfokus, data temuan dipisahkan berdasarkan jenis kelamin, usia dan lokasi, data juga diberi kode menggunakan kode 'kasus', dengan membuat 'simpul' yang terpisah untuk setiap wawancara. Berbagai 'kueri' untuk kode lebih lanjut digunakan untuk menganalisis pola, tren dan tanggapan terhadap berbagai pertanyaan dalam survei. Hasil dari kueri diekspor ke MS Word dan dianalisis untuk menulis bagian-bagian dari laporan yang merangkum temuan dan mengidentifikasi pola dan tren di dalam data.

Analisis akhir harus mencerminkan maksud dan tujuan survei. Untuk membantu melakukan analisis secara sistematis, beberapa pertanyaan penelitian dapat dikembangkan, seperti:

- Seberapa penting akses ke sumberdaya hutan untuk mata pencaharian masyarakat?

- Apakah masyarakat miskin lebih atau kurang bergantung pada sumberdaya hutan dibandingkan dengan kelompok lain?

- Bagaimana akses ke sumberdaya hutan dan implikasi mata pencaharian yang dihasilkan berbeda-beda untuk sampel survei, misalnya, sebuah kabupaten?

- Bagaimana kepemilikan lahan, hak penggunaan dan kepemilikan lahan memengaruhi mata pencaharian masyarakat? 


\section{Tahap 2 - Menggunakan hasil}

Penggunaan hasil survei akan bergantung pada tujuannya. Untuk perencanaan penggunaan lahan kolaboratif, hasilnya akan digunakan tidak hanya sebagai data dasar tetapi juga untuk menyoroti isu-isu penting - kendala dan peluang - yang dihadapi oleh masyarakat, khususnya yang berkaitan dengan penggunaan lahan dan mekanisme potensial untuk mengatasi masalah ini. Data dasar yang kuat dapat dikombinasikan dengan data biofisik untuk memberikan gambaran menyeluruh tentang situasi daerah yang disurvei (misalnya, kabupaten). Memahami masyarakat dan hubungan internal dan eksternal mereka (misalnya, dengan badan pemerintah) akan memberikan landasan yang baik dalam mengembangkan proses untuk melibatkan masyarakat dalam proses pengambilan keputusan tentang penggunaan lahan kolaboratif.

Pengalaman dari CoLUPSIA (Collaborative Land Use Planning and Sustainable Institutional Arrangements - Perencanaan Penggunaan Lahan Kolaboratif dan Penataan Kelembagaan yang Berkelanjutan) dijelaskan secara lebih rinci dalam Catatan Pendukung 9. 



\section{Catatan Pendukung 1 sampai 9}

\section{Tujuan}

Untuk mendukung 'Panduan praktis untuk survei mata pencaharian sosialekonomi dan hak dan kepemilikan lahan untuk digunakan dalam perencanaan penggunaan lahan kolaboratif yang berbasis ekosistem', telah disiapkan serangkaian Catatan Pendukung. Catatan Pendukung ini memberikan informasi tambahan dan panduan, yang dirancang untuk membantu para praktisi lapangan dalam melaksanakan survei sosial-ekonomi.

Catatan ini didasarkan pada pengalaman yang diperoleh dari proyek CoLUPSIA. Isi catatan ini belum lengkap, tetapi bertujuan untuk menutupi hal-hal penting yang diidentifikasi dan digunakan sebagai pelajaran selama pekerjaan survei diselesaikan di dua kabupaten (Kapuas Hulu dan Maluku Tengah) di Indonesia, yang secara total telah dilakukan dan melibatkan 1.366 rumah tangga.

Panduan Praktis dan Catatan Pendukung ini secara bersama-sama, termasuk contoh kuesioner yang digunakan, telah membentuk suatu alat bantu (Tool Kit) sosial-ekonomi. Alat bantu ini tersedia di situs CoLUPSIA untuk diunduh baik secara keseluruhan atau sebagian dokumen. 


\section{Catatan 1 - Definisi kunci}

Untuk memudahkan pemahaman kuesioner dan pelaksanaan survei sosialekonomi, beberapa konsep kunci yang digunakan perlu dipahami.

\section{Akses ke lahan}

'Akses ke lahan' diartikan sebagai cara seseorang/kelompok untuk mendapatkan akses atau menggunakan lahan. Di pedesaan, akses ke lahan berbasis adat-istiadat setempat ditentukan oleh pimpinan adat yang memberikan hak pakai kepada anggota masyarakat. Selain itu, akses ke lahan dapat diperoleh dengan cara membeli, menyewa, sistem bagi hasil, mendapatkan warisan atau menempati lahan secara tidak sah.

\section{Pertanyaan tertutup}

Tipe pertanyaan yang membatasi kemungkinan jawaban dari responden; tipe ini dapat dijawab dengan satu kata atau kalimat singkat.

\section{Definisi ‘hutan'1}

- Hutan adalah suatu kesatuan ekosistem berupa hamparan lahan berisi sumberdaya alam hayati yang didominasi pepohonan dalam persekutuan alam lingkungannya, yang satu dengan lainnya tidak dapat dipisahkan.

- Kawasan hutan adalah wilayah tertentu yang ditunjuk dan atau ditetapkan oleh pemerintah untuk dipertahankan keberadaannya sebagai hutan tetap.

- Hutan negara adalah hutan yang berada pada tanah yang tidak dibebani hak pribadi atas tanah.

- Hutan adat adalah hutan negara yang berada dalam wilayah masyarakat hukum adat.

- Hutan produksi adalah kawasan hutan yang mempunyai fungsi pokok menghasilkan hasil hutan (kayu).

- Hutan lindung adalah kawasan hutan yang mempunyai fungsi pokok sebagai perlindungan sistem penyangga kehidupan untuk mengatur tata air, mencegah banjir, mengendalikan erosi, mencegah intrusi air laut, dan memelihara kesuburan tanah.

- Hutan konservasi adalah kawasan hutan dengan ciri khas tertentu, yang mempunyai fungsi pokok pelestarian keanekaragaman tumbuhan dan satwa serta ekosistemnya.

1 Berdasarkan UU No 41/1999 tentang Kehutanan (Indonesia). 


\section{Rumah tangga}

Rumah tangga didefinisikan sebagai 1) kelompok orang yang hidup di bawah satu atap dan mempunyai hubungan kekerabatan; 2) menggunakan dapur atau tungku dimana mereka makan bersama dan berbagi pengeluaran untuk makanan dan minuman (lebih dari 30\% dari pendapatan individu); atau 3) tempat dimana kelompok individu tinggal bersama berbagi tenaga kerja, produksi dan konsumsi tanpa dibayar.

\section{Mata pencaharian}

Mata pencaharian mengacu kepada kemampuan seseorang untuk hidup, secara finansial, makanan maupun aset.

\section{Kepemilikan dan hak atas lahan}

'Kepemilikan dan hak atas lahan' mengacu pada pengaturan kelembagaan untuk mengelola hubungan antar individu maupun kelompok orang dengan lahan secara hukum formal maupun berdasarkan adat.

\section{Pertanyaan terbuka}

Struktur pertanyaan yang longgar, yang tidak memerlukan jawaban yang baku dan pasti sehingga responden dapat menyampaikan jawaban secara bebas dengan katakatanya sendiri.

\section{Pertanyaan semiterbuka}

Hampir sama dengan definisi pertanyaan terbuka, tetapi beberapa jawaban sudah dibuat kategorinya untuk memudahkan perekaman informasi dan analisisnya.

\section{Studi tentang mata pencaharian, kepemilikan dan hak atas lahan}

Studi ini mengenai bagaimana mata pencarian dibentuk oleh kepemilikan dan hak lahan dan bagaimana masyarakat mengelola sumberdaya alam di suatu wilayah.

\section{Kepastian hak atas lahan}

Adalah kepastian hak atas lahan yang diakui oleh pihak lain dan dilindungi dari ancaman tertentu. Individu dapat menghadapi risiko atas ketidakpastian hak lahan mereka berupa klaim pihak lain atau kerugian akibat pengusiran. 


\section{Catatan 2 - Teknik penarikan sampel}

\section{Menentukan ukuran sampel}

Ukuran sampel yang tepat sangat dipengaruhi oleh tujuan suatu penelitian. Contohnya, sensus penduduk memerlukan partisipasi seluruh penduduk sehingga ukuran sampel sebanyak jumlah penduduk (100\%). Faktor seperti keterbatasan sumberdaya (waktu, anggaran, manusia) akan menjadi pertimbangan dalam menentukan ukuran sampel, namun diperlukan kehati-hatian agar tidak menurunkan kualitas studi.

Untuk menentukan ukuran sampel, penggunaan persentase terhadap populasi bisa digunakan, contohnya mewawancarai $5 \%$ dari total rumah tangga sebagai sampel. Cara lainnya menggunakan jumlah minimum tertentu sebagai dasar penentuan sampel.

Untuk CoLUPSIA, ukuran sampel ditentukan menggunakan kombinasi pendekatan persentase dan minimum responden setiap desa (30 rumah tangga). Jumlah sampel yang disurvei sebanyak 566 rumah tangga di Maluku Tengah dan 800 rumah tangga di Kapuas Hulu.

\section{Penarikan sampel acak}

Untuk menarik sampel tahapan yang dilakukan adalah sebagai berikut:

1. Membuat daftar dari populasi keseluruhan secara berurutan, misalnya nama kepala keluarga (KK) di desa X diurutkan dari 1-250

2. Tentukan jumlah sampel yang diinginkan, contohnya, $50 \mathrm{KK}$

3. Gunakan kocokan seperti arisan, atau pemunculan angka acak dari komputer/ kalkulator untuk menentukan $50 \mathrm{KK}$ yang dipilih

4. Sampel yang terpilih disusun dalam daftar tersendiri, jika diperlukan buatlah daftar cadangan dari daftar sisa nama keluarga $(200 \mathrm{KK})$ apabila ada responden yang tidak berada di tempat atau tidak bersedia diwawancarai.

\section{Membangkitkan angka acak}

1. Kocokan arisan. Metode ini paling mudah dan tersedia bahan-bahannya di lapangan. Peneliti menuliskan angka sejumlah populasi kemudian dimasukkan ke dalam kocokan, kemudian diambil secara acak yang jumlahnya sebanyak jumlah sampel. 


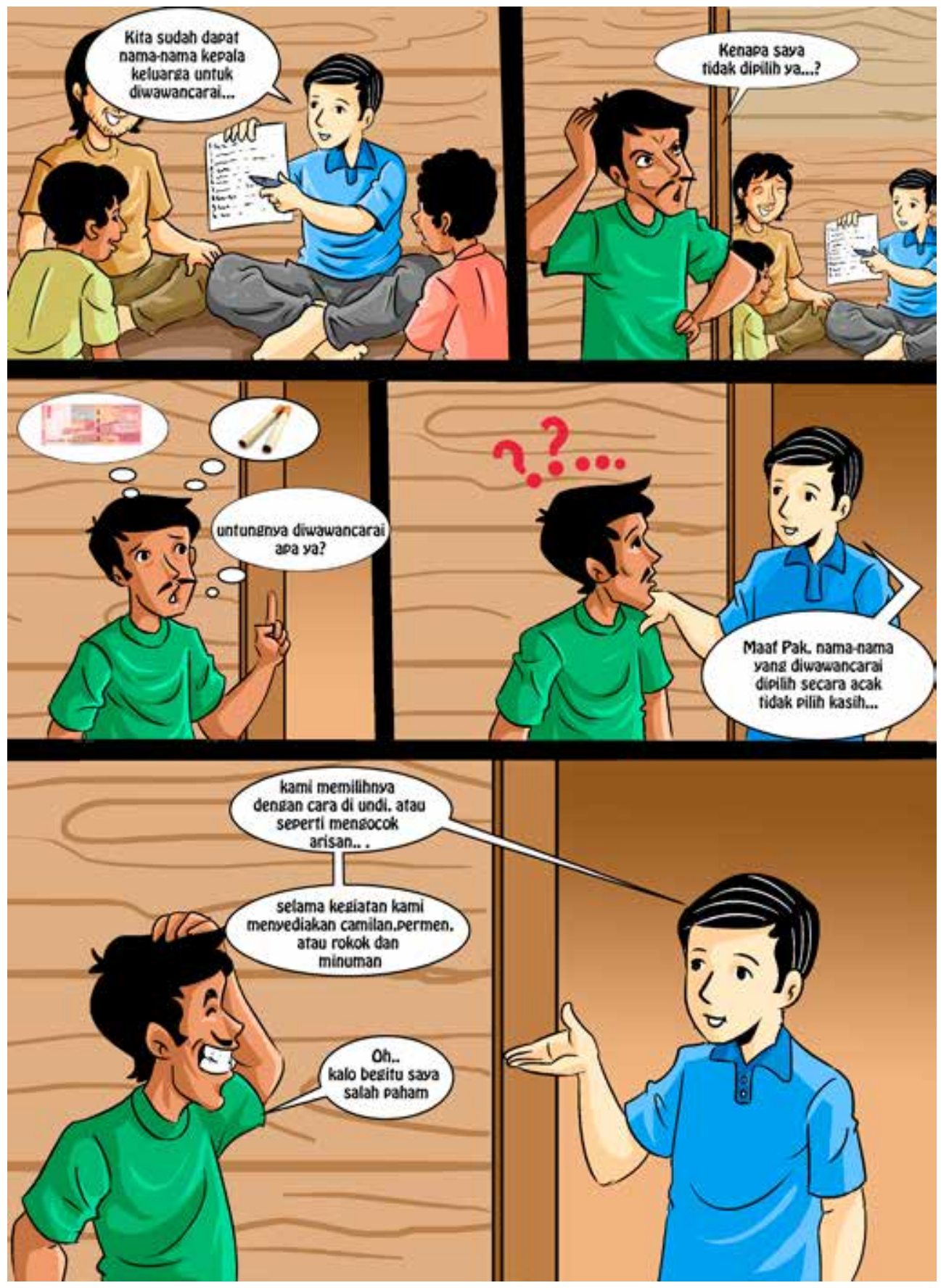


2. Kalkulator. Jika memungkinkan membawa scientific kalkulator dilengkapi fungsi pembangkitan angka random. Tahapannya adalah sebagai berikut:

a. Tentukan dahulu jumlah populasi, misalnya 50

b. Untuk mendapatkan angka acak antara 0-50, tekan tombol fungsi acak di kalkulator dan dikalikan 50, yaitu ran\#*50

c. Angka acak yang muncul dalam bentuk desimal, untuk mendapatkan angka mutlak bisa melakukan pembulatan (round) atau membuang angka desimal (trunc) misalnya, 12,6342 (round=13; trunc=12)

d. Langkah No 2c diulang kembali untuk mendapatkan sejumlah $\mathbf{n}$ sampel yang ingin ditarik.

3. Program komputer. Jika tersedia, pemunculan angka acak dapat dilakukan di program Microsoft excel dengan cara:

a. Ketik formula umum angka random, yaitu rand()

b. Ulangi langkah No 2a, 2b dan 2c, tulis kembali formula apabila memilih metode round maka formulanya adalah $=\operatorname{round}\left(50^{*} \operatorname{rand}(), 0\right)$; apabila memilih metode trunc maka formulanya menjadi $=\operatorname{trunc}(50 * \operatorname{rand}())$

Perlu diketahui bahwa fungsi "rand()" sangat sensitif dalam Excel, sehingga setiap ada pergerakan cursor saja angka acak akan terus bergerak. Karena itu setelah angka acak terbentuk, daftar angka acak yang dipakai adalah daftar yang pertama. Gunakan perintah copy - paste special - values - ok untuk menyalin tanpa mengubah nilai angka acak yang dibangkitkan. 


\section{Catatan 3 - Memilih pertanyaan yang tepat}

Ketika merancang survei dan melakukan wawancara, penting untuk mempertimbangkan struktur pertanyaan, apakah terbuka, tertutup atau kombinasi keduanya. Jenis pertanyaan dan cara bertanya akan memengaruhi jawaban yang diberikan.

Secara umum, pertanyaan dapat diajukan dalam bentuk terbuka maupun tertutup. Perbedaan keduanya terletak pada pertanyaan terbuka memberikan kesempatan kepada responden untuk menjelaskan jawabannya, sedangkan pertanyaan tertutup tidak memungkinkan hal ini.

Dengan pertanyaan tertutup, responden tidak memiliki kebebasan menjawab selain yang sudah disediakan di lembar pertanyaan. Pertanyaan semiterbuka dapat pula digunakan dalam survei sosial-ekonomi.

Kuesioner survei akan menggunakan beragam jenis pertanyaan untuk memastikan agar informasi diperoleh dengan cara yang layak.

\section{Pertanyaan terbuka}

Pertanyaan terbuka - contoh

Apa pendapat Bapak mengenai hasil panen tahun ini? Mengapa berkurang, apa yang menyebabkannya?

Pertanyaan terbuka memungkinkan peneliti menggali lebih banyak informasi dari responden karena responden mempunyai kebebasan menjawab dan memberikan penjelasan. Pertanyaan terbuka memiliki keunggulan dan kekurangan, sebagaimana tercantum dalam Tabel 1. 
Tabel 1. Keunggulan dan kelemahan pertanyaan terbuka

\begin{tabular}{|c|c|}
\hline Keunggulan & Kelemahan \\
\hline $\begin{array}{l}\text { - Dapat membantu peneliti menemukan } \\
\text { informasi baru yang sebelumnya tidak } \\
\text { terpikirkan } \\
\text { - Catatan pembicaraan dengan } \\
\text { responden dapat menjadi ilustrasi yang } \\
\text { menarik di dalam laporan. } \\
\text { - Meluaskan ruang lingkup ketika } \\
\text { analisis sehingga memungkinkan } \\
\text { munculnya interpretasi kesimpulan } \\
\text { yang baru. }\end{array}$ & $\begin{array}{l}\text { - Diperlukan pewawancara yang } \\
\text { berpengalaman untuk memulai diskusi } \\
\text { suatu topik dan mencatat temuan- } \\
\text { temuannya } \\
\text { - Analisis data dan informasi } \\
\text { membutuhkan keahlian dan waktu } \\
\text { yang cukup. }\end{array}$ \\
\hline
\end{tabular}

Untuk mengatasi kelemahan pertanyaan terbuka, maka ketika melakukan survei hal-hal berikut perlu diperhatikan:

- Melatih pewawancara dan memberikan arahan selama kegiatan berlangsung akan membantu mendapatkan kualitas data/informasi.

- Menyiapkan daftar pertanyaan secara sistematis yang memungkinkan pewawancara menggali jawaban responden.

- Pastikan mencoba pertanyaan terbuka dan berlatih bersama anggota tim.

\section{Pertanyaan semiterbuka}

\section{Pertanyaan semiterbuka - contoh:}

Selama 5 (lima) tahun terakhir, apakah hasil hutan yang dikonsumsi rumah tangga:

a. meningkat, karena......

a. berkurang, karena ......

Dalam tipe pertanyaan ini, responden diberi pilihan jawaban dalam bentuk kategori. Contoh di atas menunjukkan bahwa jawabannya hanya 'meningkat' atau 'berkurang' yang mencirikan pertanyaan tertutup, tetapi responden diberikan kesempatan menjelaskan atau alasan "karena...." (ciri pertanyaan terbuka). Tipe pertanyaan ini memiliki keunggulan dan kelemahan, diuraikan dalam Tabel 2. 
Tabel 2. Keunggulan dan kelemahan pertanyaan semiterbuka

\begin{tabular}{ll}
\hline Keunggulan & Kelemahan \\
\hline $\begin{array}{l}\text { - Jawaban mudah dicatat dan cepat, } \\
\text { analisis mudah. }\end{array}$ & Kemungkinan ada jawaban penting \\
& responden yang terlewat karena tidak \\
& ada kategori yang sesuai. \\
& Pewawancara bisa lalai karena \\
& memaksakan informasi yang masuk ke \\
& dalam kategori yang ada sementara \\
& informasi lainnya bisa hilang. \\
- Jika responden ragu menjawab, & pewawancara kemungkinan berupaya \\
& membantu dengan kisi jawaban, hal ini \\
& berpotensi bias. \\
\hline
\end{tabular}

Untuk mengatasi kelemahan di atas, maka ketika melakukan survei hal-hal berikut perlu diperhatikan:

- Jawaban responden agar dicatat dan menyediakan kertas yang cukup untuk mencatat informasi dari responden atau gunakan alat perekam.

- Jika responden tidak menjawab, usahakan mengulangi pertanyaan dengan cara berbeda serta jangan memberikan kisi-kisi jawaban.

\section{Pertanyaan tertutup}

Pertanyaan tertutup - contoh:

Apa masalah atau kendala apa yang Bapak/lbu hadapi dalam kegiatan usaha pertanian?

\begin{tabular}{llll}
\hline Serangan babi & Sering & Kadang-kadang & Jarang \\
Serangan satwa lain & Sering & Kadang-kadang & Jarang \\
Kekurangan modal & Sering & Kadang-kadang & Jarang \\
\hline
\end{tabular}

Dengan pertanyaan tertutup, responden harus memilih jawaban yang tersedia, tidak memungkinkan adanya penjelasan tambahan. Pertanyaan tertutup berguna ketika waktu penelitian terbatas dan hanya memerlukan informasi tertentu saja. Tipe pertanyaan ini memiliki keunggulan dan kelemahan, seperti dicantumkan dalam Tabel 3. 
Tabel 3. Keunggulan dan kelemahan pertanyaan tertutup

\begin{tabular}{ll}
\hline Keunggulan & Kelemahan \\
\hline - Jawaban cepat dikumpulkan dan & Analisis lanjutan dari pertanyaan \\
menghemat waktu. & tertutup dapat menyulitkan karena \\
- Membandingkan jawaban responden & pertanyaan tidak dilengkapi dengan \\
antar waktu dan kelompok & pertanyaan lain untuk menjelaskan \\
lebih mudah. & alasan responden memilih \\
& suatu pilihan. \\
\hline
\end{tabular}

Untuk mengatasi kelemahan di atas, pewawancara dapat menanyakan dan menggali alasan pemilihan jawaban. 


\section{Catatan 4 - Melaksanakan survei}

Sebelum melakukan survei, lakukan beberapa langkah berikut ini.

1. Menyiapkan secara matang dan menjadualkan kegiatan survei merupakan bagian penting kesuksesan sebuah survei. Tim survei harus menyiapkan diri, rencana kerja dan alokasi waktu penyelesaian survei harus disetujui sejak awal. Peran dan tanggung jawab tim harus jelas. Lembar data dan kuesioner harus disiapkan dan tim diberi pelatihan.

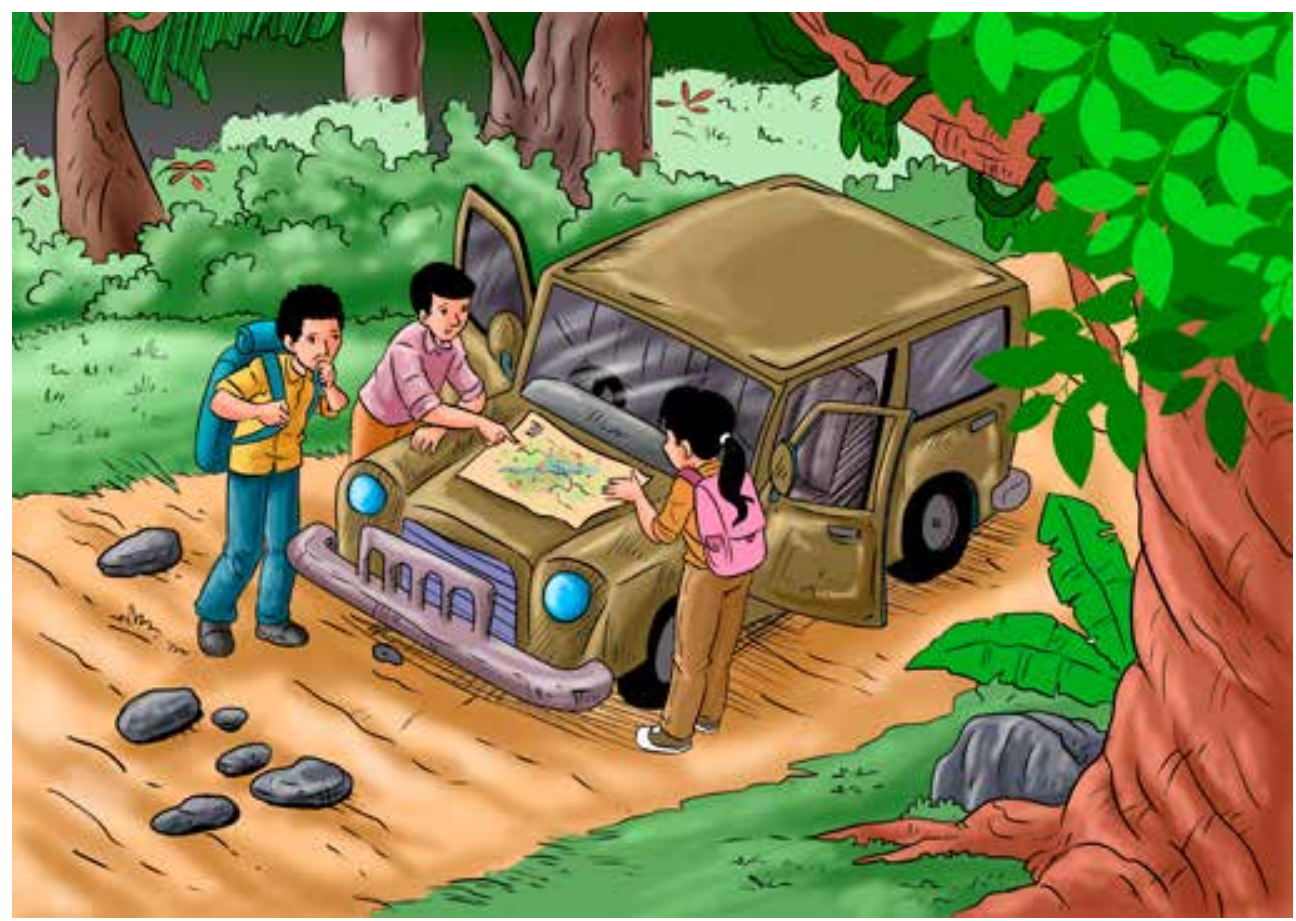

2. Meminta ijin dari kepala desa sebelum melakukan kegiatan survei. Pastikan warga desa mendapat informasi dan ijin dari kepala desa diperoleh sejak awal.

3. Jika memungkinkan, pertemuan dengan masyarakat atau dengan kepala desa dilaksanakan sebelum kegiatan dimulai, untuk mengenalkan anggota tim survei, menjelaskan tentang survei, tujuan dan bagaimana melakukannya, dan menyediakan waktu untuk pertanyaan dan diskusi dengan masyarakat atau kepala desa. Pelaksanaan pertemuan desa membutuhkan perencanaan dan 


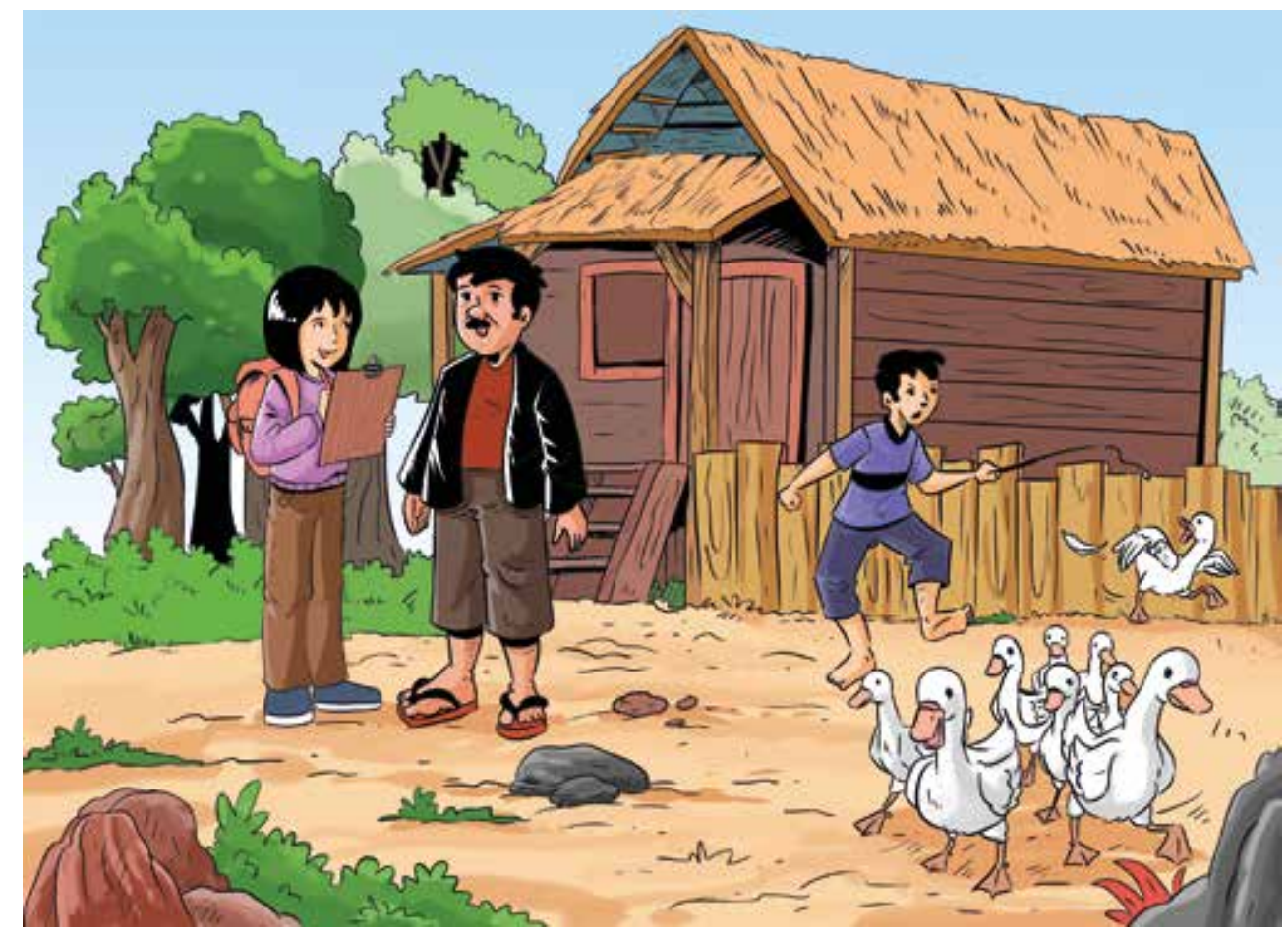

pengorganisasian mengingat pentingnya kegiatan ini di awal survei. Tim survei dapat bekerja sama dengan pimpinan desa untuk memastikan keterlibatan masyarakat desa.

4. Pastikan semua anggota tim diberi penjelasan dan pelatihan. Pastikan tidak ada perubahan tim yang telah diberi pelatihan selama survei. Ini untuk memastikan konsistensi dan kualitas data. Pelatihan harus melatih cara melakukan survei (misalnya, teknik mendengarkan, menanyakan pertanyaan terbuka) dan keterampilan mewawancarai termasuk tujuan survei dan makna setiap pertanyaan.

5. Hindari memberikan harapan kepada responden dengan menjelaskan sejelas-jelasnya mengenai kegiatan dan hasil yang mungkin dicapai. Hal ini sangat penting. 


\section{Catatan 5 - Panduan pertemuan dengan masyarakat}

Pertemuan dengan masyarakat sangat penting bagi kesuksesan survei dan langkah penting untuk melibatkan masyarakat di setiap tahapan perencanaan tata guna lahan. Membangun pelibatan masyarakat memerlukan waktu dan tidak bisa dipaksa atau terburu-buru. Survei sosial-ekonomi dan diskusi kelompok terfokus, jika dilakukan dengan benar, menjadi langkah awal membangun hubungan dengan masyarakat. Informasi yang dikumpulkan selama survei sering bersifat pribadi bahkan rahasia, dan informasi ini harus dikelola secara baik.

Panduan di bawah ini akan membantu pelaksanaan pertemuan dengan masyarakat.

- Mengatur pertemuan di tempat/balai pertemuan masyarakat, dan menyepakati waktu pertemuan dengan para tokoh.

- Mulailah dengan memperkenalkan anggota tim, lalu jelaskan latar belakang penelitian ini dan peran organisasi kita, termasuk apa yang dapat dan tidak kita berikan. Pastikan kemungkinan hasil survei dapat dipahami oleh masyarakat dan tidak memberikan harapan yang berlebihan: apa yang bisa dan tidak bisa lakukan oleh tim. Hindari membuat janji (lihat Kotak 1).

- Jelaskan kegiatan-kegiatan penelitian dan tujuan yang ingin dicapai serta sumberdaya yang akan disediakan. Jelaskan bagaimana masyarakat dapat berpartisipasi, dan bagaimana kita menginginkan bantuan mereka dan memberikan saran kepada kita.

- Jelaskan aspek-aspek penting dari jadual dan kegiatan penelitian dan simak dengan baik jika ada potensi masalah atau konflik apa saja dengan kegiatankegiatan setempat. Berusahalah untuk menentukan jadual yang bisa diterima untuk kegiatan-kegiatan utama.

- Menyilakan masyarakat memperkenalkan diri mereka/desanya. Mendapatkan informasi latar belakang tentang desa: jumlah penduduk dan jumlah keluarga, etnis, kegiatan-kegiatan masyarakat saat ini, dsb. Apakah mereka punya waktu untuk berpartisipasi dengan cara tertentu? Jika ya, kapan waktu yang cocok bagi mereka untuk melakukannya?

- Melalui diskusi-diskusi informal, mulailah untuk mengenali informan kunci yang mempunyai pengetahuan lapangan yang terkait dengan penelitian.

- Periksa apakah anggota masyarakat senang dengan kegiatan-kegiatan yang diusulkan; berikan penjelasan jika ada aspek-aspek khusus yang mungkin tidak bisa diterima. Terimalah jika ada larangan tertentu dan ubah pendekatan dengan cara lain. Mengakhiri pertemuan. Mulailah merencanakan berbagai kegiatan berdasarkan kemungkinan yang ada. 
Kotak 1. Contoh catatan penjelasan untuk mengenalkan anggota tim survei di desa

Tujuan kedatangan kami ke desa ini untuk melakukan kegiatan survei yang berkaitan dengan keadaan sosial-ekonomi masyarakat. Kegiatan ini meliputi wawancara dan diskusi kelompok.

Kami memahami bahwa waktu sangat berharga bagi masyarakat. Oleh karena itu kami akan mendiskusikan jadual kegiatan selama kami tinggal dengan kepala desa, berdasarkan waktu yang paling cocok bagi masyarakat. Kegiatan bisa dilakukan di pagi hari, siang maupun malam sesuai keberadaan responden.

Informasi yang diberikan oleh masyarakat adalah rahasia, dan kami tidak akan memberikan informasi ini kepada pihak lain yang mempunyai kepentingan berbeda. Mohon dicatat bahwa kegiatan ini tidak ada kaitannya dengan perpajakan. Kegiatan ini tidak menyediakan manfaat tunai langsung kepada masyarakat. Lebih jauh, proyek ini tidak menjanjikan suatu kegiatan akan dilakukan di desa ini di masa depan. Namun, kami percaya bahwa hasil dari studi ini akan bermanfaat bagi masyarakat di masa depan, terutama dengan meningkatnya kemampuan mendiskusikan perencanaan tata guna lahan dengan pemerintah. 


\section{Catatan 6 - Teknik wawancara}

Wawancara dapat dilakukan secara individu atau kelompok kecil sebanyak dua atau tiga orang. Sebelum wawancara, pewawancara harus menyiapkan pertanyaan dan memikirkan bagaimana wawancara akan dilakukan.

- Pakaian menunjukkan kepribadian Anda. Berpakaian yang sopan, tidak mencolok, sesuai dengan adat setempat akan meningkatkan tingkat penerimaan masyarakat desa.

- Bersikap terbuka. Proses wawancara tidak hanya sekedar 'mendapatkan data', tetapi lebih dari itu untuk memperoleh "pemahaman". Karena itu hubungan yang terjalin baik dengan masyarakat dan pemikiran yang terbuka sangat diperlukan.

- Jangan terpengaruh oleh pendapat yang sudah ada sebelumnya.

- Jawaban responden kadang terdengar tidak masuk akal, jangan berhenti meminta penjelasan sampai betul-betul mendapatkan jawaban yang dapat dimengerti.

- Di kalangan masyarakat tertentu, perempuan tidak bebas bertemu dengan tamu/orang asing. Jika memerlukan wawancara khusus dengan perempuan, usahakan komposisi tim pewawancara terbagi antara laki-laki dan perempuan sehingga pewawancara perempuan dapat mengambil data yang relevan. Perhatikan isu-isu jender. Pastikan pendekatan wawancara sesuai norma yang berlaku.

- Kemampuan mendengar dan menyadari bahwa informasi yang disampaikan oleh responden itu menarik, tidak terburu-buru dan dapat membuat responden merasa nyaman tanpa merasa terancam dengan pertanyaan pewawancara.

- Apabila mendapati responden yang antusias menjelaskan sesuatu hingga keluar dari pokok bahasan, bersikaplah sopan ketika mengalihkan pembicaraan.

Berikut ini kiat-kiat untuk membantu wawancara agar berjalan secara lancar, lihat Kotak 2. 


\section{Kotak 2. Panduan wawancara}

- Temui anggota masyarakat dan jalin hubungan, usahakan informan merasa nyaman dan rileks, perhatikan sikap badan dan bahasa tubuh.

- Jelaskan maksud dan tujuan survei dan jelaskan hal-hal yang menyangkut kerahasiaan.

- Tetapkan aturan-aturan dasar - jelaskan bahwa jika mereka tidak tahu jawabannya, tidak apa-apa. Usahakan waktunya singkat, perhatikan waktu dan jika mereka mulai gelisah, mengubah topik, kurang perhatian. Hentikan atau jika perlu istirahat. Jangan terburu-buru, bersabarlah dan tenang, tetapi serius. Gunakan bahasa yang sederhana, siapkan cara-cara lain untuk menanyakan hal yang sama. Jangan mengarahkan informan dengan mengusulkan jawaban atau pendapat Anda sendiri: sabar dan berilah waktu kepada responden untuk berpikir.

- Hormati berbagai pandangan, peraturan dan adat istiadat setempat (misalnya, seorang laki-laki tidak boleh datang sendirian dan mewawancarai responden perempuan). Tinggalkan isu yang sensitif atau tunda sampai wawancara ke dua. Jangan memaksa informan untuk menjawab.

- Biarkan informan berbicara dan bahkan sedikit menyimpang dari pertanyaan, tetapi jangan terlalu lama.

- Sediakan alat-alat peraga, peta atau gambar untuk membantu Anda menjelaskan suatu gagasan.

- Kegiatan-kegiatan, seperti membuat peta, merupakan kegiatan yang baik untuk menjaga minat masyarakat. Menyapa responden dengan senyum yang bersahabat.

- Terima mereka dengan ramah dan tawarkan beberapa kompensasi untuk pekerjaan yang tertunda, tetapi jangan membeli informasi.

- Jangan memberi janji-janji.

- Pastikan Anda menyampaikan terima kasih kepada para informan. Beritahu mereka bahwa Anda mungkin perlu kembali untuk mengecek. 


\section{Catatan 7 - Diskusi kelompok terfokus}

Diskusi kelompok terfokus (FGD) bertujuan untuk mengumpulkan informasi yang lebih dalam tentang konsep, persepsi, dan ide-ide suatu kelompok berjumlah 6-12 orang. Idealnya suatu FGD adalah lebih dari sekedar proses interaksi bertanya dan menjawab. Pelaksanaan FGD merupakan suatu proses yang berulangulang, dimana setiap diskusi dikembangkan atas diskusi sebelumnya dengan membicarakan suatu topik atau menekankan pada aspek-aspek tertentu. Kegiatan ini membutuhkan seorang fasilitator untuk memandu anggota kelompok dalam mendiskusikan topik yang dibutuhkan. Hal ini bermanfaat jika sarana penelitian yang lain seperti wawancara informan kunci, wawancara mendalam, atau teknik kualitatif lainnya digunakan berkaitan dengan FGD.

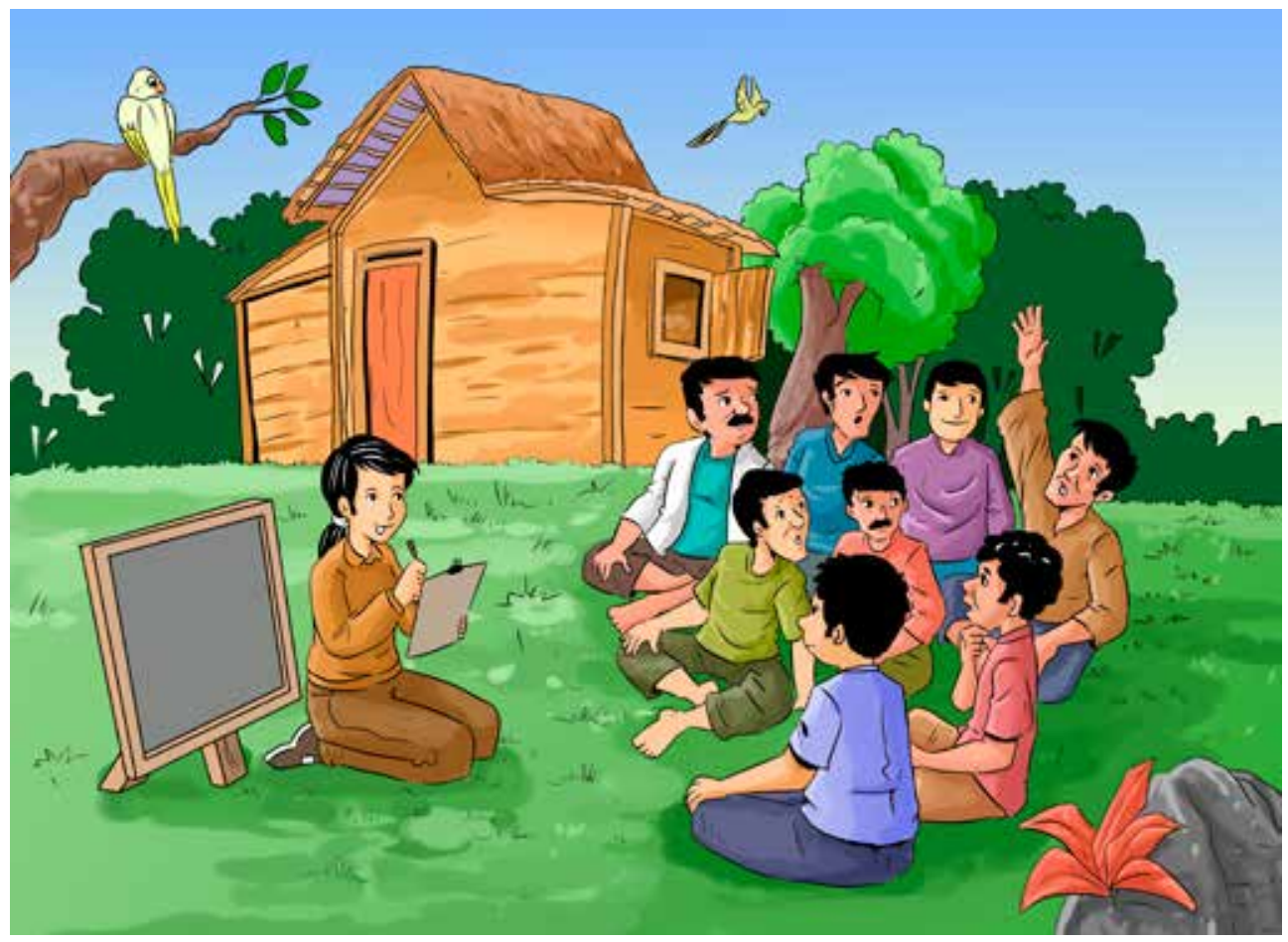

Dalam konteks proyek perencanaan penggunaan lahan kolaboratif yang melibatkan masyarakat lokal dalam kawasan hutan, suatu FGD dapat mencakup diskusi tentang tatanan kelembagaan, hak dan akses masyarakat ke hutan, 
penggunaan hutan oleh masyarakat dan pengelolaan sumberdaya hutan secara berkelanjutan. Contoh-contoh aspek yang dapat didiskusikan selama kegiatan FGD dapat dilihat di bawah ini (Tabel 4).

Sebelum melakukan FGD, anggota tim harus melakukan analisis situasi, merekrut peserta, dan mengatur sesi-sesi diskusi.

1. Analisis situasi, untuk memastikan adanya pengetahuan yang baik tentang kondisi lokal, untuk memastikan diskusi memperhitungkan isu-isu lokal dan demografi dan kondisi sosial. Ini akan membantu untuk membuat FGD yang ditargetkan.

2. Rekrutmen peserta, supaya perbedaan latar belakang yang lebar dapat terwakili di dalam kelompok. Kelompok-kelompok harus dibagi berdasarkan umur dan jender. Semua yang terlibat harus diyakinkan tentang kerahasiaan semua respon yang diberikan. Peserta harus diberitahu setidaknya satu hari sebelumnya tentang pertemuan ini untuk memastikan partisipasi yang maksimum. Jelaskan kepada peserta tentang pentingnya keragaman di dalam kelompok, yaitu untuk meyakinkan pendapat yang berbeda dapat diekspresikan.

3. Pengaturan sebelum diskusi. Komunikasi dan interaksi yang efektif menentukan kualitas hasil dari FGD. Jadi persiapan yang baik untuk FGD sangat penting. Persiapan ini termasuk pemilihan lokasi dan tempat yang

Tabel 4. Contoh tema dan topik untuk bahan diskusi dalam FGD

\begin{tabular}{ll}
\hline Tema & Topik \\
\hline - Identifikasi pemangku & - Situasi mengenai para pemangku kepentingan, \\
kepentingan & kegiatan yang dilakukan dan potensi dampaknya \\
- Hak atas sumberdaya hutan & - Pemahaman tentang hak atas sumberdaya hutan \\
& - Pola pemanfaatan sumberdaya hutan, distribusi \\
& keuntungan \\
- Pengelolaan hutan, & - Stok sumberdaya alam \\
penegakan aturan dan & - Fungsi pengelolaan hutan \\
kepatuhan & - Aturan dalam pengelolaan hutan, penegakan \\
& dan sanksi \\
- Persepsi & Pengambilan keputusan \\
Proyek pembangunan desa & Persepsi mengenai kepastian akses lahan dan \\
& Proyaimana perubahan akses telah terjadi \\
& tingkat kesuksesannya
\end{tabular}



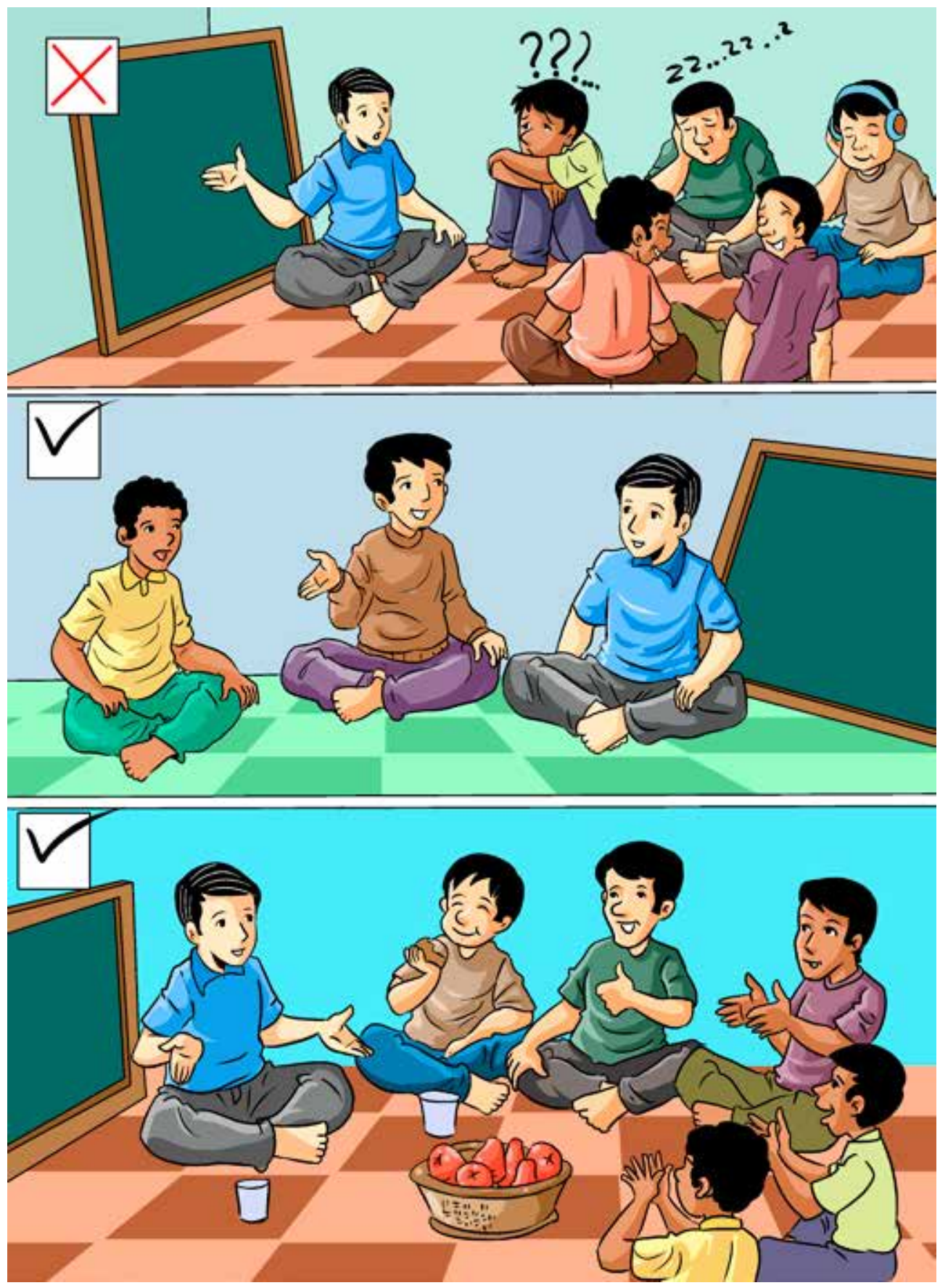
dilakukan secara hati-hati, misalnya mengatur kursi secara melingkar dan tidak dalam format ruangan kelas, untuk menghindarkan gangguan dan meyakinkan lokasinya diyakini sebagai tempat yang aman oleh semua peserta. Siapkan serangkaian daftar pertanyaan terbuka secara tertulis yang akan di bahas dalam FGD.

4. Selama sesi diskusi, pastikan pertukaran pendapat berlangsung efektif, anggota tim harus membagi tugas (misalnya, fasilitator (lihat Kotak 3), perekam/ pencatat).

\section{Kotak 3. Peran fasilitator}

- Fasilitator TIDAK harus bertindak sebagai pakar tentang topik yang didiskusikan. Peran fasilitator adalah untuk merangsang dan mengarahkan selama diskusi.

- Sebagai fasilitator, perkenalkan diri Anda dan anggota tim yang terlibat. Minta peserta mengenalkan diri dengan nama apa pun yang mereka ingin gunakan.

- Jelaskan tujuan dari FGD, jenis informasi yang dibutuhkan, dan bagaimana informasi akan digunakan. Mintalah izin untuk menggunakan alat perekam dan tekankan kembali tentang aturan kerahasiaan.

- Buat aturan diskusi yang disepakati oleh peserta, singkat dan padat. Misalnya, aturan merokok selama diskusi.

- Tunjukkan minat Anda pada ide-ide kelompok, lakukan kontak mata dengan peserta dan gunakan humor jika diperlukan. Gunakan pertanyaan yang mendorong peserta agar sebanyak mungkin mengekspresikan pandangan mereka. INGAT bahwa tidak ada jawaban 'benar' atau 'salah'. Bereaksi secara netral dan wajar terhadap respon verbal dan nonverbal.

- Bangunlah hubungan baik dan berempati, dan hindari untuk berperan sebagai ahli.

- Jangan merasa Anda harus mengatakan sesuatu dalam setiap jeda dalam diskusi. Tunggu sebentar dan perhatikan apa yang terjadi. Jaga irama diskusi. Ingat peran fasilitator adalah memastikan peserta untuk berbagi pendapat.

- Dengarkan dengan seksama dan alihkan diskusi dari satu topik ke topik lainnya secara perlahan. Jika peserta spontan berpindah ke topik yang lain, biarkan diskusi berjalan sebentar hingga muncul informasi baru yang relevan, buat kesimpulan singkat dan kembalilah ke topik diskusi semula.

- Pada akhir pertemuan, jangan lupa membuat kesimpulan dan ringkasan hasil diskusi. Tanyakan peserta jika ada yang terlupakan dalam kesimpulan. Ucapkan terima kasih atas partisipasi dan waktu yang diberikan oleh peserta. 
5. Memastikan keterlibatan aktif dari semua peserta. Hal ini penting dan anggota tim perlu bekerja bersama untuk memastikan bahwa semua peserta terlibat merata dalam diskusi. Gunakan pertanyaan yang memotivasi untuk memastikan partisipasi peserta secara aktif. Bagi kelompok untuk mengakomodasi latar belakang dan pandangan yang kontras, jika hal ini akan menciptakan diskusi yang panjang. Jika diperlukan fasilitator harus bertanya kepada kelompok untuk mendapatkan respon.

6. Mencatat proses dan intisari hasil diskusi setelah FGD adalah penting. Pencatatan ini ditekankan pada topik utama yang didiskusikan; topik yang mungkin sulit untuk didiskusikan; besarnya kesepakatan di dalam kelompok; temuan yang tidak terduga; dan jika ada perubahan yang direkomendasikan untuk FGD di masa depan.

7. Perekaman semua informasi. Keseluruhan diskusi dan semua pokok pembicaraan yang muncul harus direkam, karena proses ini didasarkan pada pertanyaan terbuka, untuk memastikan bahwa tidak ada yang terlupakan atau munculnya pokok-pokok yang di luar konteks. Hasil catatan harus dibagikan, jika memungkinkan, ditambahkan dengan hasil rekaman, menggunakan alat media yang memadai, seperti perekam suara atau sejenisnya.

8. Jumlah dan lamanya sesi; jangka waktu diskusi bervariasi menurut dinamika peserta, namun idealnya FGD akan memakan waktu antara 60 dan 90 menit. Sesi awal mungkin akan memakan waktu lebih lama saat peserta menerima informasi baru di kegiatan FGD. 


\section{Catatan 8 - Contoh kuesioner baku: Rumah tangga, desa, dan informan kunci}

Kuesioner 1. Profil desa - Informan kunci (Ka. desa, Ka. adat, dll.)

\begin{tabular}{|c|c|}
\hline Provinsi & : \\
\hline Kabupaten & \\
\hline Kecamatan & \\
\hline Desa & \\
\hline
\end{tabular}

Tanggal
Pewawancara
Pencatat

\section{Data informan kunci}

1 Nama :

2 Umur

3 Jabatan :

4 Sejak kapan menjabat/kedudukan di desa ini?

5 Apakah kecenderungan jabatan Kades turun temurun? $\square$ Ya $\square$ Tidak

\section{A. Desa}

A.1 Deskripsi desa

A.1.1 Tipe desa:

$\square$ Lama $\square$ Transmigrasi $\square$ Baru $\square$ Lainnya, sebutkan ............

A.1.2 Apakah masih ada masyarakat adat di sini, yang masih pakai hukum adat? $\square$ Ya $\square$ Tidak

A.1.3 Siapa nama kepala adat?

A.1.4 Kapan desa ini berdiri/terbentuk?

Menurut sejarah, sekitar tahun berapa di desa ini terbentuk pemukiman?

\section{A.2 Dusun/Kampung}

A.2.1 Berapa banyak jumlah dusun di desa ini? .......... buah

A.2.2 Nama masing-masing dusun? 
A.2.3 Dusun mana saja yang paling berdekatan dengan hutan?

\begin{tabular}{llll}
\hline Nama dusun & $\begin{array}{l}\text { Status hutan. KOD } \\
\text { (lihat Tabel A.2.4) }\end{array}$ & $\begin{array}{l}\text { Tahun berdiri } \\
\text { dusun }\end{array}$ & $\begin{array}{l}\text { Jarak pemukiman } \\
\text { dusun ke hutan }(\mathrm{km})\end{array}$
\end{tabular}

A.2.4 Status lahan hutan yang dimanfaatkan (KOD)
A. Kepemilikan lahan
B. Pemanfaatan lahan
Berdasarkan Hukum:
1. Dimanfaatkan oleh negara
1. Hutan negara
2. Dimanfaatkan secara bersama
2. Hutan hak
3. Dimanfaatkan oleh individu
3. Hutan adat
4. Pemanfaatan dengan ijin (meminjam)
4. Hak milik
5. Dimanfaatkan tanpa ijin
5. $\mathrm{HGU}, \mathrm{HGB}$ dan $\mathrm{HPH}$
Berdasarkan adat/kepemilikan tradisional:
1. Hutan adat
2. Hak milik

\section{A.3 Batas desa}

A.3.1 Luas desa ini? (perkiraan) .......... ha

A.3.2 Apakah batasan desa ini dengan desa lain, jelas/tidak jelas?

Ya jelas $\square$ Tidak cukup jelas

A.3.3 Apa batas administratif (1), batas alam (2) di desa ini? Sekitar berapa kilo jauh dari sini ("jarak dari pusat desa)?

\begin{tabular}{|c|c|c|c|c|c|c|}
\hline \multirow[t]{2}{*}{ Arah } & \multicolumn{2}{|l|}{ Batas administratif } & \multicolumn{2}{|c|}{ Batas alam/fisik } & \multicolumn{2}{|c|}{ Keadaan } \\
\hline & Nama desa tetangga & $\operatorname{Jarak}^{*}(\mathbf{k m})$ & Geografi & Jarak (km) & Jelas & Tidak \\
\hline
\end{tabular}

Selatan

Barat

Timur

Geografi, bisa sungai, gunung, jalan, rumah besar, dan lain lain yang bisa dilihat dan dipakai sebagai referensi 
A.3.4 Apakah ada desa-desa yang melakukan kegiatan pertanian/peternakan mereka di luar batas desa? $\square$ Ya $\square$ Tidak

A.3.5 Dimana mereka melakukan kegiatan tersebut? (lihat status lahan dan hutan, KOD)

A.4 Lingkungan desa

A.4.1 Hutan rakyat: Hutan rakyat (hutan HAK), dimiliki rakyat, di luar kawasan hutan negara

A.4.1.1 Apakah ada hutan rakyat (hutan HAK) yang dimanfaatkan masyarakat? $\square$ Ada $\square$ Tidak

A.4.1.2 Apa nama hutan rakyat (hutan HAK) itu?

A.4.1.3 Bisa tolong jelaskan situasi hutan rakyat itu?

Nama Luas Arah ${ }^{\mathrm{a}}$ Jarak $^{\mathrm{b}}$ Lama pergic Status hutan, KOD

\footnotetext{
a Arah: $1=$ Utara, $2=$ Selatan, $3=$ Barat, $4=$ Timur

b Jarak: $1=0-5 \mathrm{~km}, 2=5-10 \mathrm{~km}, 3=10-15 \mathrm{~km}, 4=$ lebih dari $15 \mathrm{~km}$

c Lama perjalanan (jalan kaki): $1=$ kurang 1 jam, $2=1-2 \mathrm{jam}, 3=2-4 \mathrm{jam}, 4=$ lebih dari setengah hari KOD diisi berdasarkan referensi status lahan (Tabel A.2.4)
}

A.4.2 Hutan adat (petuanan, ulayat dll) hutan adat: Hutan milik negara, dikelola oleh adat.

A.4.2.1 Apakah ada hutan adat yang dimanfaatkan masyarakat di sini?

Ada $\square$ Tidak ada

A.4.2.2 Apa nama hutan adat itu?

A.4.2.3 bisa tolong jelaskan situasi hutan adat itu?

\begin{tabular}{llllll}
\hline Nama Luas & Arah $^{\mathrm{a}}$ & Jarak $^{\mathrm{b}}$ & Lama pergic $^{\mathrm{C}}$ & $\begin{array}{l}\text { Di dalam } \\
\text { hutan apa }^{\mathrm{d}}\end{array}$ & $\begin{array}{l}\text { Status } \\
\text { hutan, KOD }\end{array}$ \\
\hline
\end{tabular}

a Arah: $1=$ Utara, $2=$ Selatan, $3=$ Barat, $4=$ Timur

b Jarak: $1=0-5 \mathrm{~km}, 2=5-10 \mathrm{~km}, 3=10-15 \mathrm{~km}, 4=$ lebih dari $15 \mathrm{~km}$

c Lama perjalanan (jalan kaki): $1=$ kurang 1 jam, $2=1-2$ jam, 3 = 2-4 jam, $4=$ lebih dari setengah hari

d Hutan: $1=$ hutan konservasi, $2=$ hutan lindung, $3=$ hutan produksi

KOD diisi berdasarkan referensi status lahan (Tabel A.2.4) 

A.4.3 Jarak ke Hutan Lindung
Hutan lindung dikontrol oleh negara. Masyarakat boleh memanfaatkan hutan lindung kecuali menebang pohon.
A.4.3.1 Apakah Bapak/Ibu/Saudara tahu di mana letak hutan lindung? $\square$ Ya $\square$ Tidak
A.4.3.2 Bila ya, sebutkan namanya?
A.4.3.3 Di mana arahnya dari desa ini?
$\square$ Utara $\square$ Timur $\square$ Selatan $\square$ Barat
A.4.3.4 Sekitar berapa kilometer jaraknya dari desa ini? .......... $\mathrm{km}$
A.4.3.5 Seandainya jalan kaki dari desa ini ke batas hutan lindung, berapa lama dapat ditempuh?
$\square$ Kurang satu jam $\square$ 1-2 jam $\square$ 2-4 jam $\square$ Lebih dari setengah hari

$\begin{array}{llll}\text { Nama hutan lindung } & \begin{array}{l}\text { Kategori } \\ (\mathrm{TN}-\mathrm{HL}-\mathrm{CA})\end{array}\end{array} \quad$ Arah $\quad$ Jarak (km) $\quad$ Lama (jam)

a Jarak: $1=0-5 \mathrm{~km}, 2=5-10 \mathrm{~km}, 3=10-15 \mathrm{~km}, 4=$ lebih dari $15 \mathrm{~km}$

b Lama perjalanan (jalan kaki): 1 = kurang 1 jam, $2=1-2$ jam, $3=2-4$ jam, $4=$ lebih setengah hari

A.4.4 Perusahaan

A.4.4.1 Apakah desa ini berbatasan dengan perusahaan? Perusahaan Ya (lanjut ke A.4.4.2) $\square$ Belum (lanjut ke A.4.4.2)

Tidak (lanjut ke sub B)

A.4.4.2 Apakah Bapak/Ibu tahu dimana batas antara desa dan perusahaan tersebut? $\square$ Ya $\square$ Tidak

A.4.4.3 Di mana arahnya dari desa ini?

$\square$ Utara $\square$ Selatan $\square$ Timur $\square$ Barat

A.4.4.4 Berapa kilometer jarak dari desa ini sampai batas perusahaan tersebut?

A.4.4.5 Seandainya jalan kaki dari desa ini ke batas perusahaan tersebut, berapa lama dapat ditempuh?

Kurang satu jam $\square$ 1-2 jam $\square$ 2-4 jam $\square$ Lebih dari setengah hari 
A.4.4.6 Berapa luas dan jenis kegiatan perusahaan tersebut?

\begin{tabular}{|c|c|c|c|c|c|c|c|}
\hline 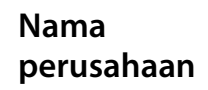 & & & raha & $\begin{array}{l}\text { Jarak } \\
(\mathrm{km})\end{array}$ & Lama $^{\text {b }}$ & $\begin{array}{l}\text { Jenis } \\
\text { kegiatanc }\end{array}$ & $\begin{array}{l}\text { Rencana/ } \\
\text { Jadi }\end{array}$ \\
\hline
\end{tabular}

a Arah: $1=$ utara, $2=$ selatan, $3=$ barat, $4=$ timur

b Lama perjalanan (jalan kaki): $1=$ kurang 1 jam, 2 = 1-2 jam, 3 = 2-4 jam, $4=$ lebih setengah hari

c Jenis kegiatan: $1=\mathrm{HPH}, 2=$ Perusahaan kelapa sawit, $3=$ Perusahaan karet, $4=$ Perusahaan coklat, $5=$ Perusahaan pengalengan ikan, $6=$ Perusahaan kelapa, $7=\mathrm{HTI}, 8=$ Perusahaan kayu (sawmill), 9 = Perusahaan Peternakan besar, $10=$ Perusahaan lain (sebut)

KOD diisi berdasarkan referensi status lahan (Tabel A.2.4)

A.4.5 Masalah perbatasan

A.4.5.1 Apakah batas desa ini jelas? $\square$ Ya $\square$ Tidak

A.4.5.2 Apakah di desa ini pernah terjadi masalah mengenai batas dengan desa tetangga atau kawasan hutan negara (batas desa maupun batas hutan)? $\square$ Ya $\square$ Tidak

A.4.5.3. Bila ya, sebutkan masalahnya?

B. Demografi

B.1 Penduduk

B.1.1 Jumlah keluarga yang tinggal di desa tahun ini? .......... KK

B.1.2 Jumlah keluarga yang tinggal di desa tahun yang lalu? .......... KK

(Jumlah keluarga tahun ini dikurangi jumlah keluarga yang baru menikah dan keluar desa)

B.1.3 Jumlah penduduk di desa ini? .......... Jiwa

B.1.4 Jumlah penduduk di desa ini tahun yang lalu? .......... Jiwa

\begin{tabular}{lllllll}
\hline & $\begin{array}{l}0-4 \\
\text { tahun }\end{array}$ & $\begin{array}{l}5-14 \\
\text { tahun }\end{array}$ & $\begin{array}{l}15-60 \\
\text { tahun }\end{array}$ & $\begin{array}{l}>60 \\
\text { tahun }\end{array}$ & Total tahun ini & Total tahun lalu \\
\hline Keluarga & $\mathrm{xxxx}$ & $\mathrm{xxxx}$ & $\mathrm{xxxx}$ & $\mathrm{xxxx}$ & \\
Laki-laki & & & & & \\
Perempuan & & & & & \\
Total & & & & & \\
\hline
\end{tabular}




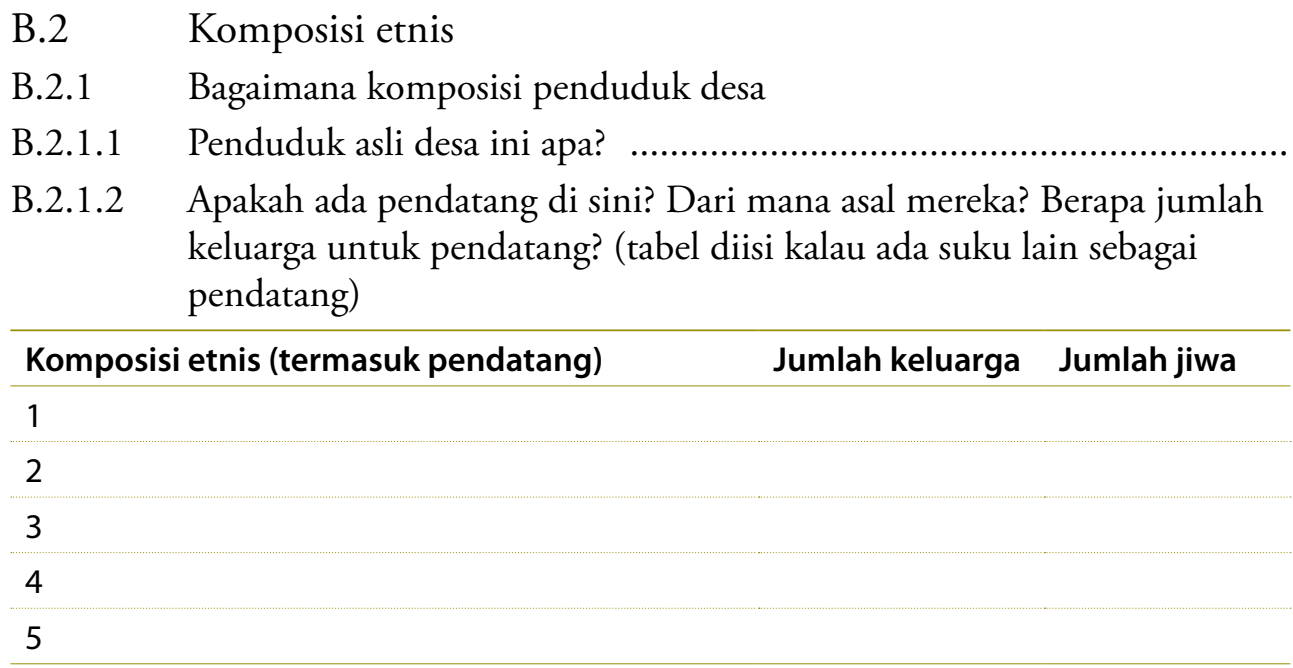

B.2.2 Bahasa daerah di sini bahasa apa?

B.3 Komposisi agama

B.3.1 Bagaimana komposisi penduduk desa ini menurut agama?

B.3.2 Jumlah sarana ibadah yang ada di desa ini?

\begin{tabular}{|c|c|c|c|}
\hline Agama & Jumlah keluarga & Tempat ibadah & Jumlah \\
\hline Kristen Protestan & & Gereja Katolik & \\
\hline Katolik & & Gereja Protestan & \\
\hline Islam & & Masjid/musholla & \\
\hline Budha & & Wihara & \\
\hline Hindu & & Pura & \\
\hline Aliran kepercayaan & & Lain (sebut) & \\
\hline
\end{tabular}
C. Sarana dan prasarana
C.1 Pendidikan
C.1.1 Jenis sekolah apa saja yang ada di desa ini?
C.1.2 Berapa gedung sekolah ada di desa ini?
C.1.3 Berapa murid masuk sekolah tahun ini? 
C.1.4 Berapa jumlah guru mengajar di sekolah yang ada di desa ini? (termasuk guru yang mengajar di sekolah tersebut, tetapi tidak tinggal di desa ini)

\begin{tabular}{l}
\hline Tingkat Jumlah murid Jumlah guru Jumlah gedung \\
\hline TK \\
SD \\
SLTP/SMP \\
SLTA/SMA \\
Perguruan tinggi
\end{tabular}

\section{C.1.5 Tingkat pendidikan penduduk}

\section{Tingkat pendidikan}

Jumlah penduduk atau $\%$

Buta huruf

SD atau di bawahnya

Tamat SLTP/SMP

Tamat SLTA/SMA

Perguruan Tinggi

C.2 Perumahan

C.2.1 Jumlah rumah di desa ini? rumah

C.2.2 Apakah ada keluarga yang tidak punya rumah di desa ini dan tinggal menetap di kebun (berumah di kebun/pondok)? $\square$ Ada $\square$ Tidak ada

C.2.3 Bila ya, ada berapa keluarga yang tidak mempunyai rumah di desa? .......... KK

C.2.4 Berapa jumlah rumah yang dibangun dalam lima tahun terakhir? buah rumah

C.2.5 Berapa jumlah kayu yang diperlukan untuk membangun satu rumah? $\mathrm{m}^{3}$

C.3 Kesehatan

C.3.1 Jenis prasarana kesehatan yang ada di desa:

Balai pengobatan $\square$ Puskesmas $\square$ Puskesmas pembantu

Rumah bidan desa $\square$ Lain

C.3.2 Jumlah tenaga medis di desa ini: orang

C.3.3 Tenaga medis tertinggi yang ada di desa:

$\square$ Mantri $\square$ Dokter $\square$ Perawat $\square$ Bidan desa $\square$ Lain

C.3.4 Frekuensi kunjungan dokter? kali/tahun - bulan - minggu 
C.3.5 Penyakit paling menonjol: 1/.

$2 /$

$3 /$.

C.3.6 Jumlah bidan yang berijazah:

orang

C.3.7 Jumlah bidan yang tidak berijazah:

orang

C.3.8 Apakah ada orang di desa ini yang masih menggunakan pengobatan tradisional (dari tanaman dan lain-lain)? $\square$ Ada $\square$ Tidak ada

C.3.9 Dari mana mereka ambil bahan obat itu?

\begin{tabular}{ll}
\hline Dari mana? & Ya Tidak \\
\hline Halaman rumah & \\
Sawah \\
Kebun \\
Ladang \\
Hutan \\
Belukar di sekitar desa \\
Lain (sebutkan)
\end{tabular}

C.4 Sanitasi lingkungan

C.4.1 Bagaimana situasi energi dan sanitasi di desa ini?

Sumber energi
Kayu bakar
Minyak tanah
Arang (tempurung kelapa)
Listrik PLN
Listrik diesel

\section{Sumber air minum}

Sumur terbuka

Sumur tertutup (sumur bor)

Air minum dari sungai

Jamban

Pakai jamban

C.5 Perhubungan

C.5.1 Hubungan ke pasar

Dimana masyarakat menjual hasil bumi?

C.5.1.1 Berapa jauh dari desa ke pasar besar terdekat? .......... km

C.5.1.2 Nama pasar terdekat? 
C.5.1.3 Berapa kali seminggu kegiatan di pasar tersebut?
$\square 1$ kali
2 kali
3 kali
Lebih dari 3 kali
Tiap hari

C.5.1.4 Berapa jauh jarak dari desa ke pasar terdekat

Jenis Jalan mobil Sungai Laut

Lama $^{a}$

Ongkos/orang

Ongkos/kilogram

Sejak kapan

Frekuensi angkutan/minggu

Akses $^{\text {b }}$

a Lama perjalanan: $1=$ kurang $1 \mathrm{jam}, 2=1-2 \mathrm{jam}, 3=2-4 \mathrm{jam}, 4=$ lebih dari $4 \mathrm{jam}$.

b Mudah/sulit menghubungi desa: $1=$ tetap bagus, $2=$ tetap bisa tetapi sulit, $3=$ bermusim

tidak bisa dilalui (150-365 bisa dilalui), 4 = biasa tidak bisa dilalui $(<150$ hari)

C.5.2 Hubungan ke kecamatan

C.5.2.1 Berapa jauh dari desa ke ibu kota kecamatan? .......... $\mathrm{km}$

C.5.2.2 Apa nama ibu kota kecamatan?

Jenis Jalan mobil Sungai Laut

Lama $^{\mathrm{a}}$

Ongkos/orang

Ongkos/kilogram

Sejak kapan

Frekuensi angkutan/minggu

Akses $^{\mathrm{b}}$

a Lama: $1=$ kurang 1 jam, $2=1-2$ jam, $3=2-4$ jam, $4=$ lebih dari 4 jam.

b Mudah/sulit menghubungi desa: $1=$ tetap bagus, $2=$ tetap bisa tetapi sulit, $3=$ bermusim tidak bisa dilalui (150-365 bisa dilalui), $4=$ biasa tidak bisa dilalui $(<150$ hari)

\section{Ekonomi desa}

D.1 Koperasi

D.1.1 Apakah di desa ini ada KUD yang aktif?

Ya $\square$ Tidak (lanjut ke pertanyaan D.1.3.)

D.1.2 Kegiatan KUD, antara lain (isi tabel di bawah ini)

Kegiatan Kios bersama Simpan/pinjam Kios sarprodia Pemasaran Lain (sebut)
Ya/Tidak
a Sarprodi $=$ sarana produksi


D.1.3 Dimana masyarakat bisa memperoleh pinjaman uang/kredit?

\begin{tabular}{|c|c|c|c|c|c|}
\hline Sumber pinjaman & $\mathrm{Ya}$ & Tidak & Sumber pinjaman & $\mathrm{Ya}$ & Tidak \\
\hline Bank & & & IDT & & \\
\hline KUD & & & Arisan & & \\
\hline Kas desa & & & Lain (sebut) & & \\
\hline Tauke & & & & & \\
\hline
\end{tabular}

D.2 Prasarana dan saprodi pertanian

D.2.1 Apakah di sini ada lahan irigasi? $\square$ Ada $\square$ Tidak ada (lanjut ke D.2.2.)

Prasarana Sejak tahun Luas (ha) Jumlah keluarga

Irigasi sederhana

Irigasi semi-teknis

Irigasi teknis

D.2.2. Apa produk pertanian yang paling penting?

\begin{tabular}{lllll}
\hline Jenis penggunaan lahan & Produk 1 & Produk 2 & \multicolumn{2}{c}{ Produk 3} \\
\hline & Nama Ha & Nama Ha & Nama Ha \\
\hline Kebun rumah & & & & \\
Ladang & & & & \\
Sawah & & & & \\
Kebun tanaman & & & & \\
\hline
\end{tabular}

D.2.3 Berapa luas lahan yang ditanam dengan tanaman pertanian utama?

D.2.3.1 Apakah di desa ini sudah menggunakan bibit unggul? $\square$ Ya $\square$ Tidak

\begin{tabular}{|c|c|c|c|c|c|}
\hline \multirow{2}{*}{ Komoditas } & \multicolumn{2}{|c|}{ D.2.3: Jenis utama tanaman pertanian } & \multicolumn{3}{|c|}{ D.2.3.1: Bibit unggul } \\
\hline & Luas total lahan* & Status lahan, KOD & Luas $^{*}$ & Sejak & Jumlah KK \\
\hline \multicolumn{6}{|l|}{ Jagung } \\
\hline Padi & & & & & \\
\hline
\end{tabular}

Karet

Kelapa

Lain (sebut)

* dalam hektar (ha)

KOD diisi berdasarkan referensi status lahan (Tabel A.2.4) 
D.2.3.2 Apakah di desa ini sudah menggunakan pupuk/pestisida (obat-obatan)/ herbisida/fungisida? $\square \mathrm{Ya}$ (isi tabel di bawah) $\square$ Tidak

\begin{tabular}{|c|c|c|c|c|c|c|c|c|c|c|c|c|}
\hline \multirow[t]{2}{*}{ Komoditas } & \multicolumn{3}{|c|}{ Pupuk } & \multicolumn{3}{|c|}{ Pestisida } & \multicolumn{3}{|c|}{ Herbisida } & \multicolumn{3}{|c|}{ Fungisida } \\
\hline & $\begin{array}{l}\text { Luas } \\
\text { (ha) }\end{array}$ & Sejak & KK & $\begin{array}{l}\text { Luas } \\
\text { (ha) }\end{array}$ & Sejak & KK & $\begin{array}{l}\text { Luas } \\
\text { (ha) }\end{array}$ & Sejak & KK & $\begin{array}{l}\text { Luas } \\
\text { (ha) }\end{array}$ & Sejak & KK \\
\hline
\end{tabular}

Jagung

Padi

Karet

Lain ............

D.2.4 Aset desa

D.2.4.1 Berapa jumlah gergaji rantai (chainsaw) yang beroperasi di desa ini .......... buah

D.2.4.2 Berapa warga yang memiliki gergaji rantai di desa ini .......... keluarga

D.2.4.3 Kepemilikan aset di desa?

Jumlah total

Jumlah KK yang memiliki

Mobil/truk

Sepeda motor

TV

Parabola antenna

CD/VCD/DVD/player

Telepon genggang/telpon

Radio

Perahu motor/mesin ketinting

Kulkas 
D.2.5 Ongkos kegiatan pertanian

D.2.5.1 Harga tanah/ha

\begin{tabular}{|c|c|c|c|c|}
\hline \multirow[t]{2}{*}{ Jenis Lahan } & \multicolumn{2}{|l|}{ Beli } & \multicolumn{2}{|c|}{ Sewa/setahun } \\
\hline & Kosong & Sudah ditanami & Kosong & Sudah ditanami \\
\hline \multicolumn{5}{|l|}{ Lahan kering dekat desa } \\
\hline \multicolumn{5}{|l|}{ Lahan kering jauh dari desa } \\
\hline Lahan buka baru & & & & \\
\hline
\end{tabular}

D.2.5.2 Biaya produksi pertanian (upah harian kerja)

\begin{tabular}{llll}
\hline Jenis lahan & $\begin{array}{l}\text { Membajak lahan/ } \\
\text { menanami }\end{array}$ & Merawat/menyiangi Panen & \\
\cline { 2 - 5 } & Laki-laki Perempuan & Laki-laki Perempuan & Laki-laki Perempuan
\end{tabular}

Ladang

Kebun

D.2.5.3 Biaya membuka tanah (1 ha)/luas membuka lahan menurut kebiasaan setempat:

D.2.5.3.1 Berapa luas rata-rata orang membuka lahan pertanian? Luas

D.2.5.3.2 Berapa biaya pembukaan lahan kebun/belukar maupun hutan?

\begin{tabular}{|c|c|c|c|c|}
\hline \multirow[t]{2}{*}{ Borongan upah harian kerja } & \multicolumn{2}{|c|}{ Kebun/belukar } & \multicolumn{2}{|l|}{ Hutan } \\
\hline & Hari kerja & Upah harian & Hari kerja & Upah harian \\
\hline \multicolumn{5}{|l|}{$\begin{array}{l}\text { Menebang pohon (termasuk } \\
\text { sewa gergaji/chainsaw) }\end{array}$} \\
\hline \multicolumn{5}{|l|}{$\begin{array}{l}\text { Membelah/membagi/ } \\
\text { menggergaji pohon }\end{array}$} \\
\hline \multicolumn{5}{|l|}{ Mengangkut kayu } \\
\hline \multicolumn{5}{|l|}{ Membersihkan lahan } \\
\hline Membakar lahan & & & & \\
\hline
\end{tabular}

D.2.5.4 Siapa di desa ini yang memutuskan untuk membuka lahan baru?

$\square$ Keluarga sendiri $\square$ Kepala desa $\square$ Kolektif tingkat masyarakat Lain (menjelaskan) 
D.2.6 Apa hasil utama di desa ini, dan bila dijual, dalam bentuk apa?

\begin{tabular}{|c|c|c|c|c|c|c|c|c|c|c|}
\hline \multirow{3}{*}{$\begin{array}{l}\text { Hasil } \\
\text { pertanian }\end{array}$} & & & \multicolumn{6}{|c|}{ Kalau dijual, apa bentuknya dan berapa harganya? } & \multirow{3}{*}{$\begin{array}{l}\text { Bentuk } \\
\text { jual } \\
\text { (kering/ } \\
\text { basah) }\end{array}$} & \multirow{3}{*}{$\begin{array}{l}\text { Pembeli } \\
\text { ke } \\
\text { petani/ } \\
\text { ke pasar }\end{array}$} \\
\hline & & & \multirow[t]{2}{*}{ Kotor } & \multicolumn{2}{|c|}{ Harga/Kg } & \multirow[t]{2}{*}{ Bersih } & \multicolumn{2}{|c|}{$\mathrm{Harga} / \mathrm{Kg}$} & & \\
\hline & Satuan* & $\begin{array}{l}\text { Berapa } \\
\text { hasil? }\end{array}$ & & $\begin{array}{l}\text { Tahun } \\
\text { lalu }\end{array}$ & $\begin{array}{l}\text { Tahun } \\
\text { ini }\end{array}$ & & $\begin{array}{l}\text { Tahun } \\
\text { lalu }\end{array}$ & $\begin{array}{l}\text { Tahun } \\
\text { ini }\end{array}$ & & \\
\hline Padi & & & Gabah & & & Beras & & & & \\
\hline
\end{tabular}

Catatan: *) jika menggunakan ukuran lokal (UL), berapa UL = $\mathrm{kg}$

D.2.7 Kelompok tani

D.2.7.1 Apakah di desa ini sudah ada kelompok tani?

Ya $\square$ Tidak (lanjut ke D.3.)

D.2.7.2 Untuk jenis tanaman apa? (sebutkan di tabel di bawah)

D.2.7.3 Apakah kelompok tani itu secara

$\square$ Formal (resmi) $\square$ Informal (isi tabel di bawah)

D.2.7.4 Berapa jumlah anggota tani laki-laki?

D.2.7.5 Apakah ada kelompok tani wanita? (isi tabel di bawah)

\begin{tabular}{|c|c|c|c|c|}
\hline elompok tani & Jenis tanaman & $\begin{array}{l}\text { Status } \\
\text { (formal/informal) }\end{array}$ & $\begin{array}{l}\text { Jumlah anggota } \\
\text { laki-laki }\end{array}$ & $\begin{array}{l}\text { Jumlah anggota } \\
\text { perempuan }\end{array}$ \\
\hline
\end{tabular}

D.3 Peternakan dan perikanan

D.3.1 Jenis ternak di desa ini?

\begin{tabular}{l}
\hline Jenis $\quad$ Jumlah ekor $\quad$ Jumlah keluarga \\
\hline Kerbau \\
Sapi \\
Kuda \\
Babi \\
Kambing/domba \\
Bebek/itik \\
Ayam \\
Lain (sebutkan) ........... \\
\hline a Sistem pemeliharaan: $1=$ liar, $2=$ ikat, $3=$ kandang malam, $4=$ gembala, $5=$ kandang tetap
\end{tabular}

a Sistem pemeliharaan: $1=$ liar, $2=$ ikat, $3=$ kandang malam, $4=$ gembala, $5=$ kandang tetap 
D.3.2 Harga ternak

\begin{tabular}{|c|c|c|c|c|c|c|}
\hline & & & $\begin{array}{l}\text { Harga/ } \\
\text { ekor }\end{array}$ & & & $\begin{array}{l}\text { Harga/ } \\
\text { ekor }\end{array}$ \\
\hline \multirow[t]{4}{*}{ Kerbau } & \multirow[t]{2}{*}{ Jantan } & Dewasa & Babi & \multirow[t]{2}{*}{ Jantan } & Dewasa & \\
\hline & & Anak & & & Anak & \\
\hline & \multirow[t]{2}{*}{ Betina } & Dewasa & & \multirow[t]{2}{*}{ Betina } & Dewasa & \\
\hline & & Anak & & & Anak & \\
\hline \multirow[t]{4}{*}{ Sapi } & \multirow[t]{2}{*}{ Jantan } & Dewasa & & & & \\
\hline & & Anak & & & & \\
\hline & \multirow[t]{2}{*}{ Betina } & Dewasa & & & & \\
\hline & & Anak & & & & \\
\hline \multirow{4}{*}{$\begin{array}{l}\text { Kambing } \\
\text { /domba }\end{array}$} & \multirow[t]{2}{*}{ Jantan } & Dewasa & Bebek & & & \\
\hline & & Anak & Ayam & & & \\
\hline & \multirow[t]{2}{*}{ Betina } & Dewasa & $\ldots \ldots \ldots$ & & & \\
\hline & & Anak & 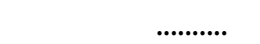 & & & \\
\hline
\end{tabular}

D.3.3 Perikanan (Darat/Laut)

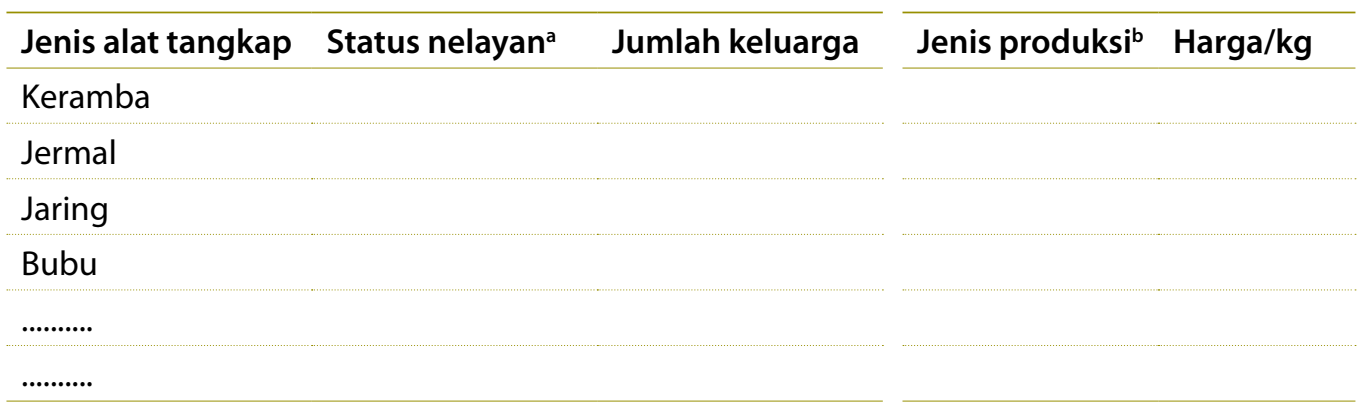

a Status: $1=$ tetap sepanjang tahun, $2=$ musiman, $3=$ tidak tetap dalam tahun, $4=$ tidak tetap antar tahun, 5 = budidaya

b Tulis jenis produksi/budidaya seperti tangkapan ikan utama, rumput laut, dsb. 
D.4 Kegiatan ekonomi

D.4.1 Kegiatan sumber penghidupan yang paling penting? (kalau bisa diurutkan dari yang paling penting)

\begin{tabular}{l}
\hline No Kegiatan \\
\hline 1 \\
2 \\
3 \\
4 \\
5 \\
6 \\
7 \\
8 \\
a Status: $1=$ tetap sepanjang tahun, $2=$ musiman, $3=$ tidak tetap dalam tahun, $4=$ tidak tetap \\
antar tahun
\end{tabular}

D.4.2 Pengambilan hasil hutan

No Kegiatan Status ${ }^{\text {a }} \begin{aligned} & \text { Jumlah Harga/Unit } \\ & \text { keluarga }\end{aligned}$
$\begin{aligned} & \text { Diambil dari } \\ & \text { mana (KOD) }\end{aligned}$
2
3
4
5
6
7
8
a Status: $1=$ tetap sepanjang tahun, $2=$ musiman, $3=$ tidak tetap dalam tahun, $4=$ tidak tetap
antar tahun

KOD diisi berdasarkan referensi status lahan (Tabel A.2.4)

D.4.2.1 Berapa jumlah kayu bakar digunakan oleh keluarga (2 dewasa, 3 anak) dalam satu bulan?

D.4.2.2 Berapa unit kayu dipakai untuk membangun 1 rumah biasa (dihuni oleh 2 dewasa, 2 anak)? $\mathrm{m}^{3}$ 
D.5 Distribusi penggunaan lahan

\begin{tabular}{|c|c|c|c|c|}
\hline \multirow[t]{2}{*}{ Luas (Hektar) } & \multicolumn{4}{|c|}{ Jumlah KK } \\
\hline & Ladang & $\begin{array}{l}\text { Kebun } \\
\text { komoditas } \\
\text { I........... }\end{array}$ & $\begin{array}{l}\text { Kebun } \\
\text { komoditas } \\
\text { II.......... }\end{array}$ & $\begin{array}{l}\text { Kebun } \\
\text { komoditas } \\
\text { III.......... }\end{array}$ \\
\hline
\end{tabular}

Tidak memiliki lahan

$0,1<$ lahan $<1$ hektar

$1<$ lahan < 1,9 hektar

$2<$ lahan $<4,9$ hektar

$5<$ lahan $<10$ hektar

Di atas 10 hektar

E. Program pembangunan

E.1 Bantuan pembangunan desa (lima tahun terakhir) dari pemerintah

\begin{tabular}{llll}
\hline Jenis program & Tahun & $\Sigma$ Keluarga & Jenis kegiatan \\
Keberhasilan
\end{tabular}

a Keberhasilan: 1 = sangat berhasil, $2=$ berhasil, $3=$ setengah berhasil, $4=$ kurang berhasil, $5=$ tidak berhasil

Catatan: Inpres untuk bantuan desa tidak termasuk (karena rutin - tiap desa dapat)

E.2 Kegiatan LSM

\begin{tabular}{llll}
\hline Jenis program & Tahun & $\Sigma$ Keluarga & Jenis kegiatan \\
Keberhasilan $^{\mathrm{a}}$
\end{tabular}

a Keberhasilan: 1 = sangat berhasil, 2 = berhasil, $3=$ setengah berhasil, $4=$ kurang berhasil, $5=$ tidak berhasil 
E.3 Kegiatan kehutanan

\begin{tabular}{llll}
\hline Jenis program & Tahun & $\Sigma$ Keluarga & Jenis kegiatan \\
Keberhasilan $^{\mathrm{a}}$
\end{tabular}

a Keberhasilan: 1 = sangat berhasil, 2 = berhasil, $3=$ setengah berhasil, $4=$ kurang berhasil, $5=$ tidak berhasil

\section{F. Permasalahan hutan dan desa}

\begin{tabular}{llll}
\hline Bentuk-bentuk masalah & $\begin{array}{l}\text { Ada/ } \\
\text { tidak ada }\end{array}$ & $\begin{array}{l}\text { Tahun } \\
\text { kejadian }\end{array}$ & $\begin{array}{l}\text { Keterangan } \\
\text { penting }\end{array}$ \\
\hline
\end{tabular}

Sebagian besar warga tidak tahu status hutan

Tata batas hutan belum jelas

Tata batas sudah jelas tetapi belum diterima

oleh masyarakat

Lahan masyarakat di dalam kawasan

Pengambilan kayu oleh orang luar desa

Pengambilan kayu oleh orang desa

Penangkapan satwa/burung

Ada gangguan kegiatan tradisional di hutan

Alat/barang disita pihak kehutanan

Terjadi banjir/tanah longsor rutin

Hama dari hutan

Kebakaran hutan di sekitar desa

Kebakaran kebun di sekitar desa

Masa paceklik desa

Persengketaan tanah antar desa

Persengketaan tanah dalam desa

Pencurian ternak masyarakat

Wabah penyakit ternak

Hama belalang, tikus, wereng

Wabah penyakit manusia

Masalah kekeringan/kurang air bersih

Masalah lainnya, sebutkan 


\section{Catatan penting:}




\section{Kuesioner 2. Survei rumah tangga}

$\begin{array}{ll}\text { Provinsi } & : \text {. } \\ \text { Kabupaten } & : \ldots \ldots \ldots \ldots\end{array}$

Tanggal :

Pencatat

A. Data umum

A.1 Keluarga

A.1.1 Nama responden:

A.1.2 Berapa usia Bapak/Ibu:

A.1.3 Jenis kelamin $\square$ Laki-laki $\square$ Perempuan

A.1.4 Apakah Anda kepala keluarga ini? $\square$ Ya (A.1.6) $\square$ Tidak (A.1.5)

A.1.5 Hubungan dengan kepala keluarga $\square$ Suami $\square$ Istri $\square$ Anak $\square$ Lainnya

A.1.6 Apakah Anda lahir di desa ini? $\square$ Ya $\square$ Tidak

A.1.7 Apakah Anda asli berasal dari desa ini? $\square$ Ya $\square$ Tidak,

A.1.8 Jumlah anak $\square$......... Laki-laki $\square$......... Perempuan

A.1.9 Jumlah tanggungan

Anak laki-laki $\square$.......... Anak perempuan $\square$.......... Orang tua

A.1.10 Orang (selain keluarga inti) yang masih ditanggung dan tinggal di rumah ( $>6$ bulan) $\square$......... Laki-laki $\square$......... Perempuan

A.1.11 Komposisi rumah tangga

\begin{tabular}{|c|c|c|c|}
\hline Umur (tahun) & Laki-laki & Perempuan & Jumlah \\
\hline \multicolumn{4}{|l|}{$0-4$} \\
\hline \multicolumn{4}{|l|}{$5-14$} \\
\hline \multicolumn{4}{|l|}{$15-60$} \\
\hline \multicolumn{4}{|l|}{$>60$} \\
\hline Jumlah & & & \\
\hline
\end{tabular}




\begin{tabular}{|c|c|c|}
\hline A. 2 & Data pendidikan & \\
\hline A.2.1 & Jumlah anak yang sedang sekolah & \\
\hline Sekolah & Laki-laki & Perempuan \\
\hline \multicolumn{3}{|l|}{ SD } \\
\hline \multicolumn{3}{|l|}{ SMP } \\
\hline \multicolumn{3}{|l|}{ SMA } \\
\hline \multicolumn{3}{|c|}{ Perguruan Tinggi (PT) } \\
\hline Jumlah & & \\
\hline
\end{tabular}

A.2.2 Ijazah tertinggi untuk anggota keluarga yang tidak bersekolah lagi

\begin{tabular}{|c|c|c|c|c|}
\hline & SD & SMP & SMA & PT \\
\hline \multicolumn{5}{|l|}{ Suami } \\
\hline \multicolumn{5}{|l|}{ Istri } \\
\hline \multicolumn{5}{|l|}{ Anak laki-laki } \\
\hline Anak perempuan & & & & \\
\hline
\end{tabular}

B. Data pertanian musim tanam yang lalu

B.1 Sistem pertanian musim tanam yang lalu

B.1.1 Pada musim tanam yang lalu, apakah Bapak/Ibu mengusahakan kegiatan pertanian $\square$ Ya $\square$ Tidak (B.1.3)

B.1.2 Di lahan siapa, kegiatan pertanian dilakukan?

Milik sendiri (Tabel B.1.6) $\square$ Orang lain (Tabel B.1.8)

B.1.3 Apakah Bapak/Ibu memiliki lahan yang dikerjakan orang lain? Ya (isi Tabel B.1.8) $\square$ Tidak

B.1.4 Apakah tanah yang Bapak usahakan memiliki sertifikat?

$\square$ Ya $\square$ Tidak

B.1.5 Apa jenis sertifikat tersebut

\begin{tabular}{l}
\hline Sertifikat \\
\hline Hak milik \\
Hak guna usaha $($ ha) \\
Hak guna bangunan \\
Girik, SKT (surat keterangan tanah) \\
Lainnya
\end{tabular}


B.1.6 Kegiatan pertanian musim tanam yang lalu - menggarap lahan/ tanah sendiri

\begin{tabular}{|c|c|c|c|c|c|}
\hline \multicolumn{6}{|c|}{ Lahan milik sendiri, mengusahakan sendiri } \\
\hline Jenis lahan & Jarak $^{\mathbf{b}}$ & Dimanac KOD $^{c}$ & $\begin{array}{l}\text { Tanaman } \\
\text { utama }\end{array}$ & Sejak & $\begin{array}{l}\text { Tanaman } \\
\text { lainnya }\end{array}$ \\
\hline
\end{tabular}

Tanaman pangan

Ladang

Kebun sayuran

Pekarangan

Sawah (irigasi, rawa *)

Padang rumput

penggembalaan

Kebun/dusun *)

Kebun karet

Kebun

\footnotetext{
a Kalau pakai ukuran lokal, 1 ukuran lokal $=$ ha atau $\mathrm{m}^{2}$

b Jarak dihitung dari lamanya jalan kaki ke lokasi (dalam menit)

c Arah dan nama lokal (kalau ada)

*) coret yang tidak perlu
}

Pengisian KOD, lihat Tabel B.1.7

B.1.7 Status Lahan Hutan yang dimanfaatkan (KOD)
A. Kepemilikan Lahan
B. Pemanfaatan Lahan
Berdasarkan Hukum
1. Dimanfaatkan oleh negara
1. Hutan negara
2. Dimanfaatkan secara bersama
2. Hutan hak
3. Dimanfaatkan oleh individu
3. Hutan adat
4. Pemanfaatan dengan ijin (meminjam)
4. Hak milik
5. Dimanfaatkan tanpa ijin
5. HGU, HGB dan $\mathrm{HPH}$
Berdasarkan adat/kepemilikan tradisional:
1. Hutan adat
2. Hak milik 
B.1.8 Kegiatan pertanian musim tanam yang lalu - mengusahakan lahan/tanah orang lain atau lahan/tanah dikerjakan oleh orang lain

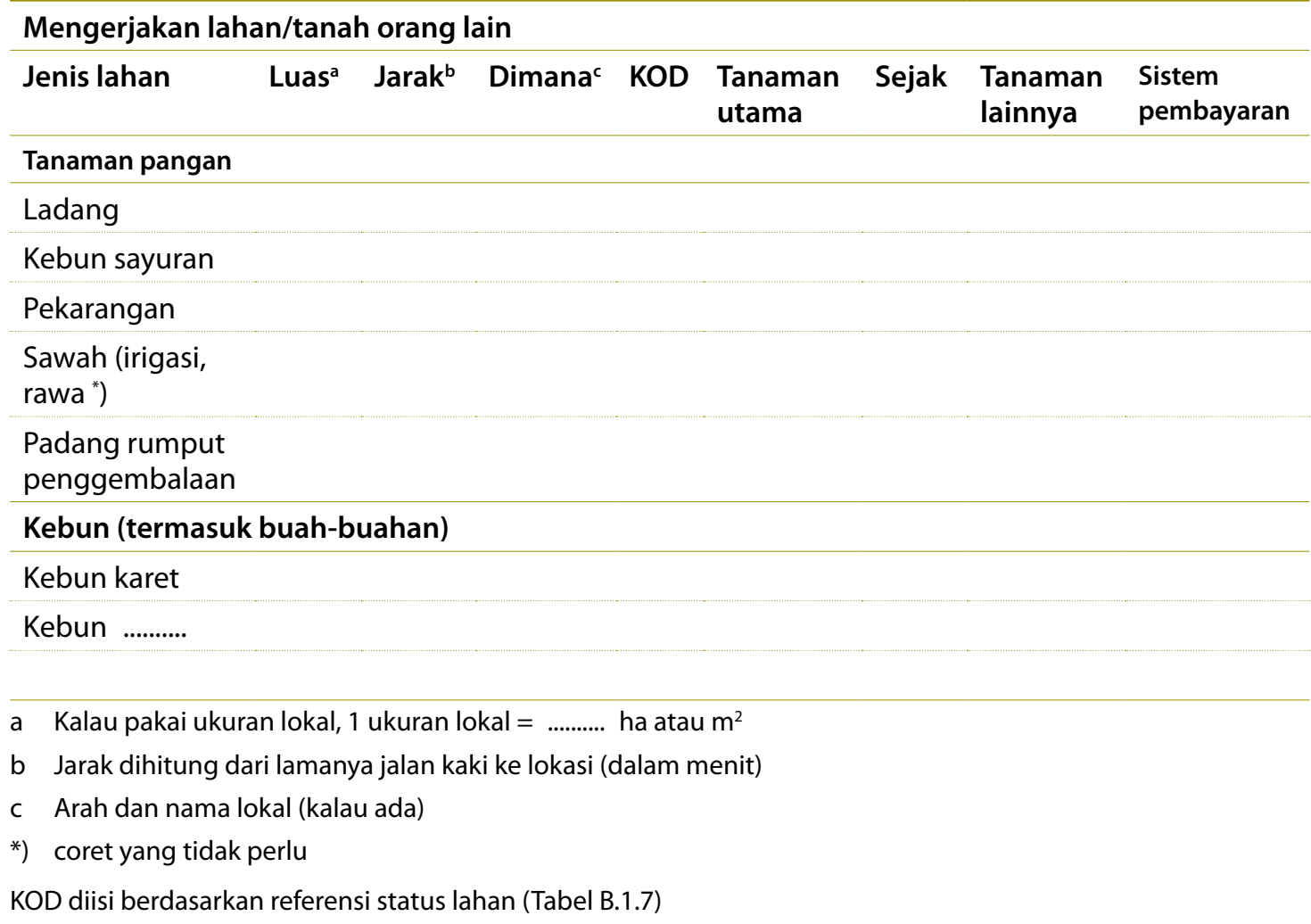

B.2 Sarana produksi yang dipakai pada musim tanam yang lalu

B.2.1 Apakah Bapak/Ibu menggunakan bibit/pupuk/insektisida/herbisida pada lahan yang ditanami tanaman pangan pada musim tanam yang lalu:

$\square$ Ya (isi tabel B.2.2) $\square$ Tidak (B.3)

B.2.2 Sarana produksi lahan tanaman pangan

\begin{tabular}{llllllllllll}
\hline Komoditas & Bibit & \multicolumn{3}{c}{ Pupuk } & & Herbisida & Insektisida & Fungisida \\
\cline { 2 - 11 } & $\mathrm{Kg}$ & $\mathrm{Rp}$ & Nama & $\mathrm{Kg}$ & $\mathrm{Rp}$ & $\mathrm{Kg}$ & $\mathrm{Rp}$ & $\mathrm{Kg}$ & $\mathrm{Rp}$ & $\mathrm{Kg}$ & $\mathrm{Rp}$ \\
\hline
\end{tabular}

Padi ladang

Jagung 
B.2.3 Sarana produksi lahan perkebunan

\begin{tabular}{llllllllllll}
\hline Komoditas & Bibit & & \multicolumn{3}{c}{ Pupuk } & & \multicolumn{2}{c}{ Herbisida } & \multicolumn{2}{c}{ Insektisida } & Fungisida \\
\cline { 2 - 10 } & $\mathrm{Kg}$ & $\mathrm{Rp}$ & Nama & $\mathrm{Kg}$ & $\mathrm{Rp}$ & $\mathrm{Kg}$ & $\mathrm{Rp}$ & $\mathrm{Kg}$ & $\mathrm{Rp}$ & $\mathrm{Kg}$ & $\mathrm{Rp}$ \\
\hline
\end{tabular}

Karet

B.3. Tenaga kerja

B.3.1 Apakah Bapak/Ibu menggunakan tenaga kerja di luar keluarga?

B.3.2 Biaya tenaga kerja: Lahan tanaman pangan (tahun yang lalu)

\begin{tabular}{llllll}
\hline Komoditas & Biaya tenaga kerja di luar keluarga (dalam Rupiah) & & \\
\cline { 2 - 4 } & $\begin{array}{l}\text { Pengolahan/ } \\
\text { membajak tanah }\end{array}$ & Menanam & $\begin{array}{l}\text { Merawat/ Panen } \\
\text { menyiangi }\end{array}$ & $\begin{array}{l}\text { Pengolahan } \\
\text { bahan panen }\end{array}$ & $\begin{array}{l}\text { Penjualan } \\
\text { (termasuk } \\
\text { transport) }\end{array}$ \\
\hline
\end{tabular}

Padi

Jagung

B.3.3 Biaya dan tenaga kerja di luar keluarga: Kebun (tahun yang lalu)

\begin{tabular}{|c|c|c|c|c|c|c|}
\hline \multirow[t]{2}{*}{ Komoditas } & \multicolumn{6}{|c|}{ Biaya tenaga kerja di luar keluarga (dalam Rupiah) } \\
\hline & Menanam & Memupuk & $\begin{array}{l}\text { Merawat/ } \\
\text { menyiangi }\end{array}$ & Panen & $\begin{array}{l}\text { Pengolahan } \\
\text { bahan } \\
\text { panen }\end{array}$ & $\begin{array}{l}\text { Penjualan } \\
\text { (termasuk } \\
\text { angkutan) }\end{array}$ \\
\hline
\end{tabular}

Karet 

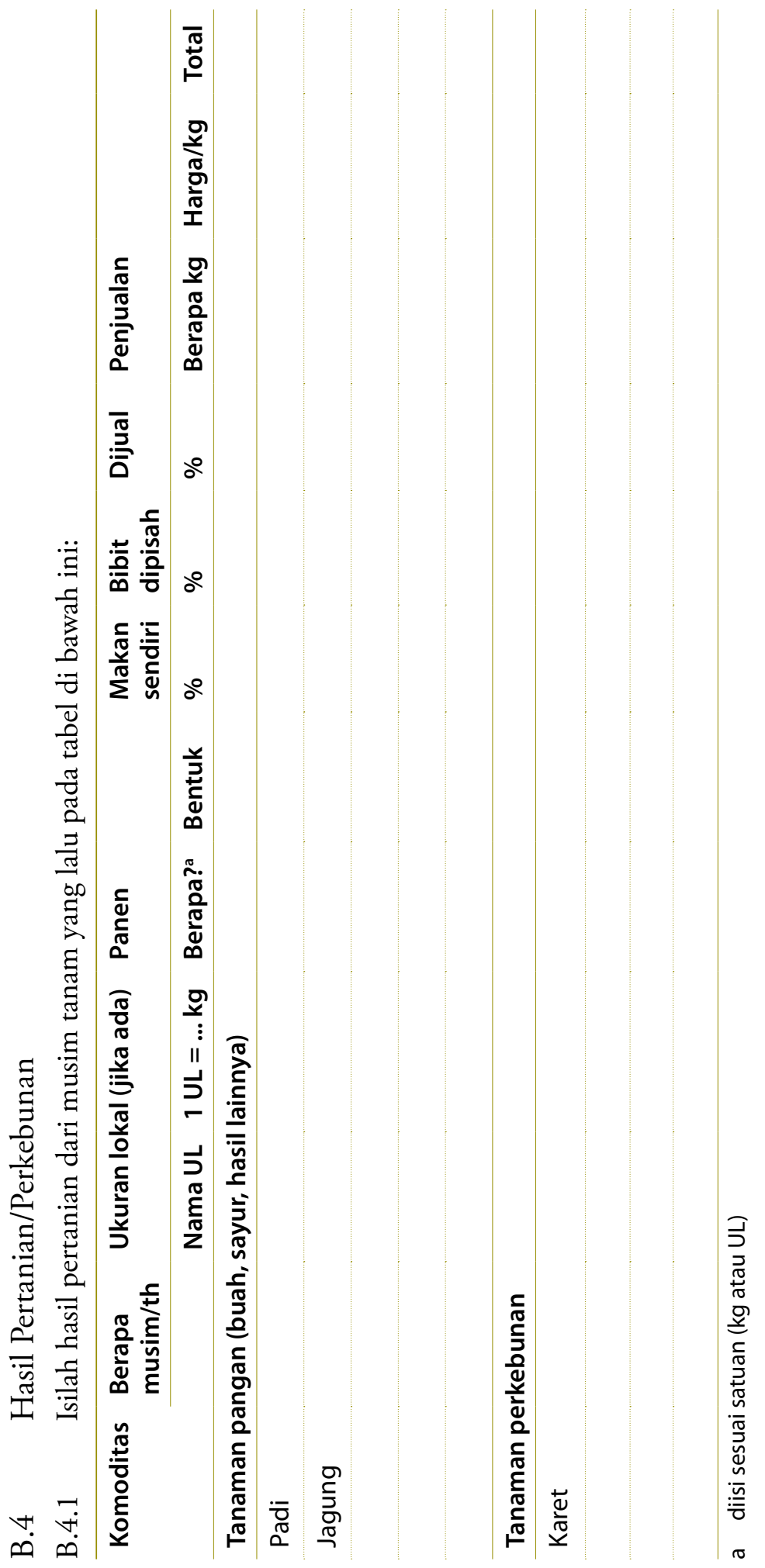
C. Data pertanian pada musim tanam saat ini

C.1.1 Jenis lahan yang digarap pada musim tanam saat ini?

C.1.2 Apakah Anda telah membuka lahan baru sejak musim tanam yang lalu?

C.1.3 Apakah Anda punya rencana untuk memperluas kebun Anda atau membuka lahan baru?

C.1.4 Apakah Anda punya rencana untuk memperbarui (mengganti tanaman) kebun Anda?

C.1.5 Apakah Anda punya rencana untuk mengurangi lahan Anda?

C.1.6 Apakah Anda punya rencana untuk meninggalkan lahan Anda?

C.1.7 Lahan digarap: Ladang - kebun

\begin{tabular}{|c|c|c|c|c|}
\hline & & Ladang & Kebun & Lainnya \\
\hline C.1.1 & Sama/tidak ${ }^{*}$ ) & & & \\
\hline \multirow{2}{*}{$\begin{array}{l}\text { Jenis lahan digarap musim } \\
\text { tanam sekarang }\end{array}$} & Luas & & & \\
\hline & Tanaman lainnya & & & \\
\hline C.1.2 & Ya/tidak *) & & & \\
\hline \multirow{3}{*}{$\begin{array}{l}\text { Pembukaan lahan baru sejak } \\
\text { musim tanam lalu }\end{array}$} & Luas & & & \\
\hline & Dimana & & & \\
\hline & KOD & & & \\
\hline C.1.3 & Ya/tidak ${ }^{*}$ ) & & & \\
\hline \multirow{3}{*}{$\begin{array}{l}\text { Apakah ada rencana } \\
\text { perluasan lahan }\end{array}$} & Luas & & & \\
\hline & Dimana & & & \\
\hline & KOD & & & \\
\hline C.1.4 & Ya/tidak ${ }^{*}$ ) & & & \\
\hline \multirow{2}{*}{$\begin{array}{l}\text { Apakah ada rencana } \\
\text { pergantian tanaman }\end{array}$} & Luas & & & \\
\hline & Tanaman apa & & & \\
\hline C. 1.5 & Ya/tidak *) & & & \\
\hline \multirow{3}{*}{$\begin{array}{l}\text { Apakah ada rencana } \\
\text { mengurangi lahan }\end{array}$} & Luas & & & \\
\hline & Dimana & & & \\
\hline & KOD & & & \\
\hline \multirow{4}{*}{$\begin{array}{l}\text { C.1.6 } \\
\text { Apakah ada rencana } \\
\text { meninggalkan lahan }\end{array}$} & Ya/tidak *) & & & \\
\hline & Luas & & & \\
\hline & Dimana & & & \\
\hline & KOD & & & \\
\hline
\end{tabular}

Untuk mengisi KOD lihat Tabel B.1.7 
C.2 Apakah lahan yang sekarang dimanfaatkan dapat terus dimanfaatkan sampai 5 tahun lagi?

Tidak bisa (lanjutkan ke C.3) $\square$ Belum tahu $\square$ Ya

C.3 Apa alasan lahan tidak bisa dimanfaatkan sampai 5 tahun lagi?

a. Tidak punya sertifikat

b. Saya hanya punya akses sementara

c. Lahannya pinjaman

d. Hak atas lahan bisa dicabut sewaktu-waktu

e. Hak atas lahan tidak ditegakkan

f. Ada pembatasan pemanfaatan lahan oleh pemerintah

g. Persaingan dengan sesama penduduk desa

h. Persaingan dengan penduduk desa tetangga

i. Persaingan pemanfaatan lahan dengan perusahaan (dari luar desa)

j. Pembangunan infrastruktur/jalan

$\mathrm{k}$.

1 .

Catatan: jika jawaban lebih dari 1 (satu), minta responden memberikan peringkat alasan berdasarkan nilai pentingnya

D. Peternakan dan perikanan

D.1 Apakah Bapak memiliki ternak?

$\square$ Ya, dan dipelihara sendiri (isi tabel D.1.1)

$\square$ Ya, dan dipelihara oleh orang lain (isi tabel D.1.6)

$\square$ Tidak (D.1.7) 


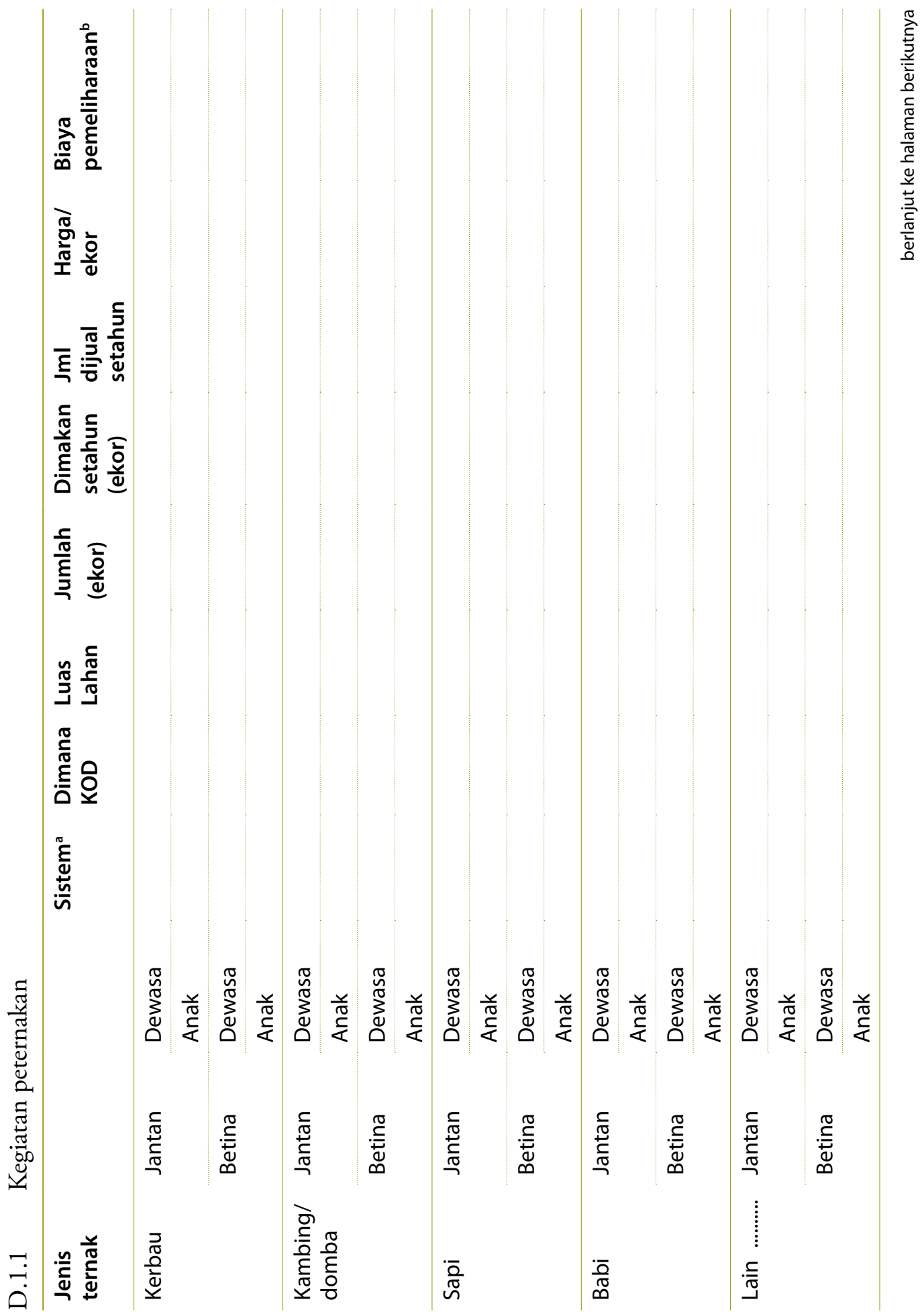




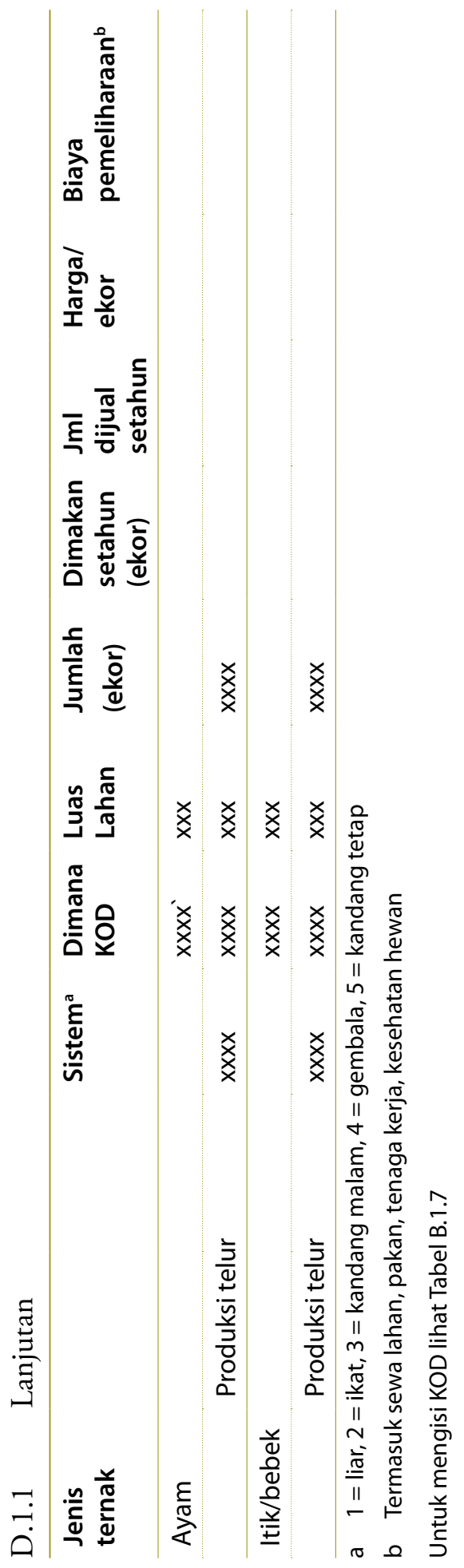


D.1.2 Produk turunan dari kegiatan peternakan

\begin{tabular}{lllll}
\hline Jumlah panen & Satuan & $\begin{array}{l}\text { \% dipakai } \\
\text { sendiri }\end{array}$ & $\%$ dijual & $\begin{array}{l}\text { Harga jual/ } \\
\text { unit }\end{array}$ \\
\hline Susu & & & \\
Mentega & & & \\
Kulit & & & \\
Pupuk & & & \\
\hline
\end{tabular}

D.1.3 Sistem pembayaran kalau hewan dipelihara orang lain

Siapa yang menanggung biaya?

Berapa biayanya? Rp Sistem pembayarannya

$\mathrm{Rp}$ .$/$ tahun

D.1.4 Apakah Anda memelihara hewan orang lain?

$\square$ Ya (tabel D.1.6) $\square$ Tidak (D 1.7)

D.1.5 Pendapatan yang diperoleh dari memelihara hewan orang lain?

Sistem pembayaran .......... Pendapatan yang diterima $\mathrm{Rp}$........../tahun

D.1.6 Memelihara hewan milik orang lain

\begin{tabular}{|c|c|c|c|c|}
\hline Hewan Ternak & $\begin{array}{l}\text { Sistem } \\
\text { pemeliharaan }^{a}\end{array}$ & Luas tanah & $\begin{array}{l}\text { Dimana } \\
\text { KOD }\end{array}$ & $\begin{array}{l}\text { Jumlah } \\
\text { (ekor) }\end{array}$ \\
\hline \multicolumn{5}{|l|}{ Kerbau } \\
\hline \multicolumn{5}{|c|}{ Kambing/domba } \\
\hline \multicolumn{5}{|l|}{ Sapi } \\
\hline \multicolumn{5}{|l|}{ Babi } \\
\hline \multicolumn{5}{|l|}{ Ayam } \\
\hline \multicolumn{5}{|l|}{ Itik/bebek } \\
\hline Lainnya & & & & \\
\hline
\end{tabular}

a $1=$ liar, $2=$ ikat, $3=$ kandang malam, $4=$ gembala, $5=$ kandang tetap

Untuk mengisi KOD lihat Tabel B.1.7 
D.1.7 Apakah Anda memiliki kolam ikan? $\square$ Ya (Tabel D.1.7.1) $\square$ Tidak D.1.7.1 Kegiatan perikanan - Kolam ikan/karamba

\begin{tabular}{ll}
\hline Komponen & Satuan \\
\hline Luas & Ha \\
\hline Jumlah kolam/karamba & Buah \\
Sistem pemeliharaan ${ }^{\mathrm{a}}$ & \\
\hline Tujuan $^{\mathrm{b}}$ & \\
\hline Dari panen ikan:\% konsumsi sendiri & \\
\% dijual & Rp/tahun \\
\hline Biaya setahun (pakan dan pemasaran) & Rp/tahun \\
\hline Penjualan setahun & \\
\hline a $1=$ tetap, $2=$ musiman & \\
b $1=$ konsumsi, $2=$ dijual &
\end{tabular}

D.1.8 Apakah Anda menjadi nelayan sungai/danau/laut? $\square$ Ya $\square$ Tidak

\begin{tabular}{|c|c|c|c|}
\hline & Hasil 1 & Hasil 2 & Hasil 3 \\
\hline Status penggun & & & \\
\hline Tangkapan ikan & & & \\
\hline
\end{tabular}

\section{Siapa yang pergi ${ }^{b}$}

Frekuensic $^{c}$

Tidak melaut $^{\mathrm{d}}$

Jumlah tangkapan $1 \times$ melaut

Satuannya apa?

$\%$ dimakan sendiri

$\%$ dijual

\section{Berapa harga/satuan}

Biaya sekali melaut (pergi-pulang)

a Jarak: 1 = kurang dari 1 jam, $2=2-4$ jam, 3 = 4-8 jam, $4=$ lebih dari 8 jam

b Siapa: 1 = Ayah, $2=\mathrm{lbu}, 3=$ Ayah dan ibu, $4=$ Ayah dan anak, $5=\mathrm{lbu}$ dan anak, $6=$ Anak,

$7=$ Seluruh keluarga

c Frekuensi: $1=$ tiap hari, $2=$ tiap minggu, $3=2$ kali sebulan, $4=$ tiap bulan, $5=$ dua bulan sekali, $6=$ dua kali setahun, $7=$ kurang dari 2 kali setahun

d Tidak melaut karena musim: $1=1$ minggu, $2=2$ minggu, $3=1$ bulan, $4=2$ bulan, $5=3$ bulan, 6 = lebih dari 3 bulan

Untuk mengisi KOD lihat Tabel B.1.7 
E. Masalah dalam kegiatan pertanian/perkebunan/peternakan/ perikanan

- catat masalah/kendala yang diucapkan oleh responden secara spontan

E.1 Masalah atau kendala apa yang dihadapi Bapak/Ibu dalam kegiatan usaha tani?

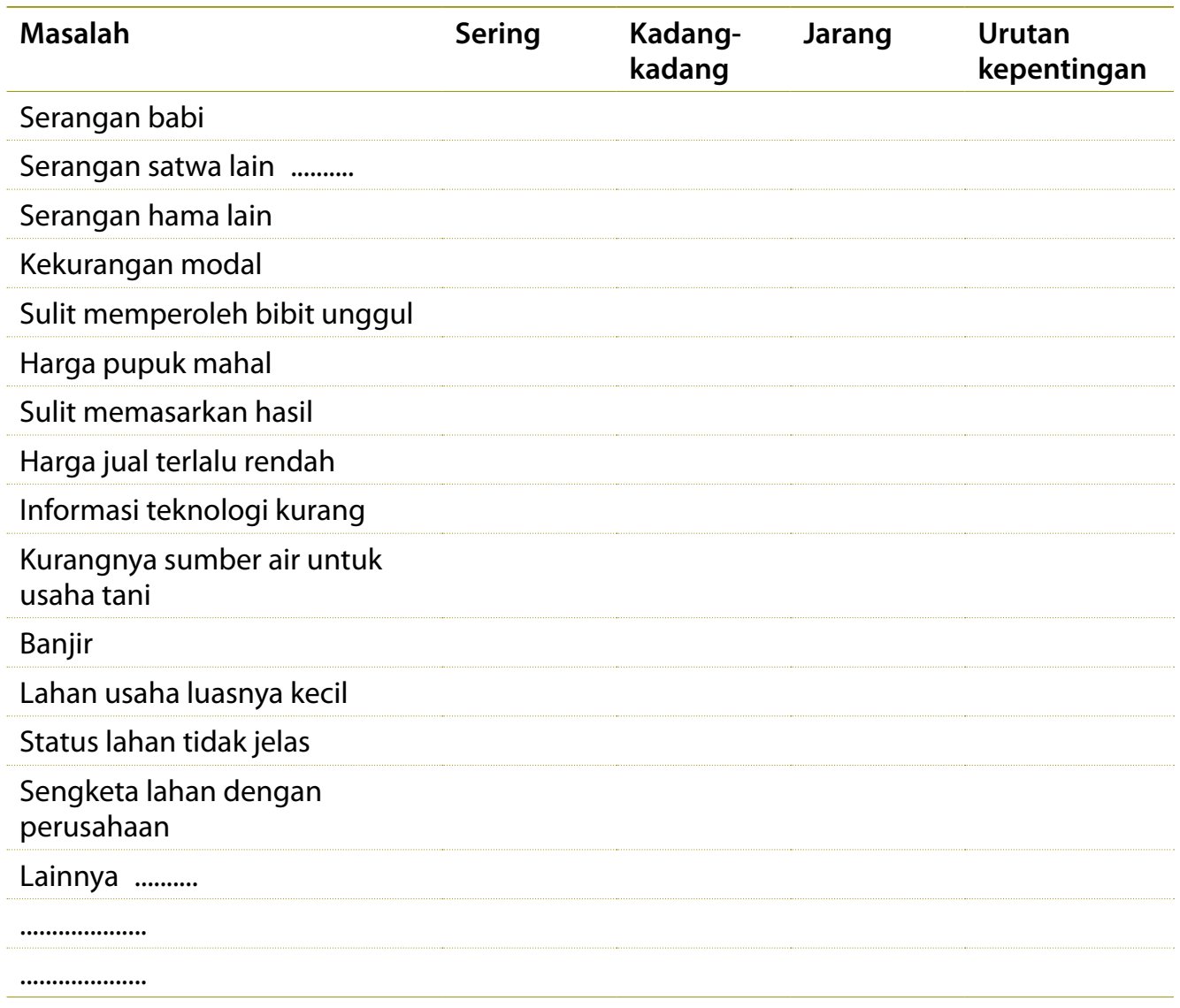

E.2 Apakah pernah mengalami situasi-situasi berikut ini selama 5 (lima) tahun terakhir?

\section{Aspek Kerentanan}

Ya/tidak*)

Mengalami penurunan/kehilangan pendapatan

secara tiba-tiba

Kegagalan panen

Bencana alam (banjir, kekeringan, gempa, angin

putting beliung, hama dan virus *)

Pengusiran dari rumah oleh

Pengusiran dari lahan oleh 
E.2 Lanjutan

\begin{tabular}{|c|c|c|}
\hline Aspek Kerentanan & Ya/tidak*) & $\begin{array}{l}\text { Apa yang dilakukan } \\
\text { untuk mengatasinya? }\end{array}$ \\
\hline
\end{tabular}

Kebakaran rumah

* pilih yang sesuai

F. Penyuluhan dan Organisasi Sosial

F.1 Apakah Anda menjadi anggota perkumpulan/organisasi di tingkat desa? $\square$ Ya $\square$ Tidak

F.1.1 Penyuluhan

\begin{tabular}{|c|c|c|}
\hline Tenaga penyuluh & Topik penyuluhan & Frekuensi \\
\hline \multicolumn{3}{|c|}{ Petugas Pertanian, PPL } \\
\hline \multicolumn{3}{|c|}{ Petugas Keluarga Berencana } \\
\hline Petugas Kehutanan & & \\
\hline
\end{tabular}

F.2 Apakah Anda pernah menerima bantuan atau partisipasi dalam program pembangunan masyarakat yang dilakukan oleh organisasi eksternal (pemerintah, LSM, dll) $\square$ Ya $\square$ Tidak

F.2.1 Bantuan pembangunan masyarakat selama 5 tahun terakhir

Tahun Nama program Nama organisasi Deskripsi kegiatan Tingkat kesuksesan ${ }^{\mathrm{a}}$

a $1=$ sangat sukses, $2=$ sukses, $3=$ agak sukses, $4=$ kurang sukses, $5=$ tidak sukses

F.3 Apakah Anda anggota organisasi?

F.3.1 Keanggotaan organisasi

Nama organisasi Status organisasi ${ }^{a}$ Anggota sejak tahun? Deskripsi kegiatan

a $1=$ formal, 2 = informal 
G. Hasil hutan

G.1 Apakah Anda mengambil hasil hutan bukan kayu? $\square$ Ya $\square$ Tidak (G.2)

G.1.1 Pemanfaatan hasil hutan non-kayu (HHNK)

\begin{tabular}{|c|c|c|c|c|c|c|c|c|c|c|}
\hline Hasil hutan & 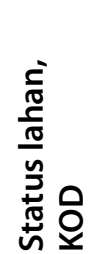 & $\frac{\sqrt{7}}{\frac{\pi}{2}}$ & $\begin{array}{l}0 \\
\stackrel{0}{0} \\
i \frac{\pi}{n}\end{array}$ & 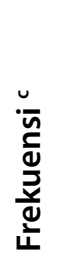 & 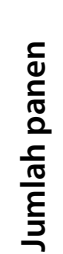 & 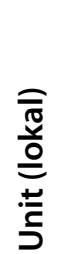 & 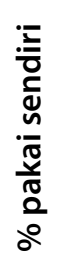 & $\frac{\pi}{2}$ & 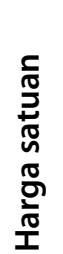 & $\begin{array}{l}\text { Persepsi status } \\
\text { sumberdaya }+/-^{*} \text { ) }\end{array}$ \\
\hline & & & & & & & & & & Perempua \\
\hline
\end{tabular}

Madu

Rotan

Anggrek

Daun atap

Sayuran

Babi hutan

Getah karet

Tanaman

obat

a Jarak: $1=$ kurang dari 1 jam, $2=2-4$ jam, $3=4-8$ jam, $4=$ lebih dari 8 jam

b Siapa: $1=$ Ayah, $2=\mathrm{lbu}, 3=$ Ayah dan ibu, $4=$ Ayah dan anak, $5=\mathrm{lbu}$ dan anak, $6=$ Anak,

$7=$ Seluruh keluarga

c Frekuensi: 1 = tiap hari, 2 = tiap minggu, $3=2$ kali sebulan, $4=$ tiap bulan, $5=$ dua bulan sekali, $6=$ dua kali setahun, $7=$ kurang dari 2 kali setahun

Untuk mengisi KOD lihat Tabel B.1.7

G.2 Apakah hutan yang sekarang dimanfaatkan dapat terus dimanfaatkan sampai 5 tahun lagi?

$\square$ Tidak bisa (lanjutkan ke G.3) $\square$ Belum tahu $\square$ Ya

G.3 Apa alasan hutan tidak bisa dimanfaatkan sampai 5 tahun lagi?

a. Status hutan tidak jelas

b. Batas hutan tidak jelas 
c. Hak atas lahan bisa dicabut sewaktu-waktu

d. Hak atas lahan tidak ditegakkan

e. Ada pembatasan pemanfaatan oleh pemerintah

f. Persaingan dengan sesama penduduk desa

g. Persaingan dengan penduduk desa tetangga

h. Persaingan pemanfaatan lahan dengan perusahaan (dari luar desa)

i. Pembangunan infrastruktur/jalan

j.

$\mathrm{k}$.

Catatan: jika jawaban lebih dari 1 (satu), minta responden memberi peringkat alasan berdasarkan nilai pentingnya

G.4 Hasil kayu

G.4.1 Pemanfaatan hasil kayu (kayu bakar dan kayu gergajian/untuk bahan bangunan)

\begin{tabular}{l}
\hline Kayu bakar Kayu bangunan 1 Kayu bangunan 2 \\
\hline Nama jenis kayu \\
Lokasia $^{\text {a }}$ \\
Status lahan, KOD \\
Jarak (lamanya) \\
Siapa yang pergic \\
Frekuensi \\
Jumlah diambil \\
Satuannya apa? (ikat, $\mathrm{m}^{3}, \ldots \ldots . .$. ) \\
\% dipakai sendiri \\
\% dijual \\
Berapa harganya/satuan \\
a Lokasi: $1=$ Hutan, $2=$ Ladang, $3=$ Belukar \\
b Jarak: $1=$ kurang dari 1 jam, $2=2-4$ jam, $3=4-8$ jam, $4=$ lebih dari 8 jam \\
c Siapa: $1=$ Ayah, $2=$ Ibu, $3=$ Ayah dan ibu, $4=$ Ayah dan anak, $5=$ lbu dan anak, $6=$ Anak, \\
$7=$ Seluruh keluarga \\
Untuk mengisi KOD lihat Tabel B.1.7
\end{tabular}


H. Persepsi tentang perubahan

H.1 Dalam 5 (lima) tahun terakhir, apakah ketersediaan lahan hutan untuk dibuka:
a. meningkat (ke H.2)
b. tidak berubah
c. berkurang (ke H.3)
d. tidak tahu

H.2 Jika ketersediaan lahan hutan untuk dibuka MENINGKAT, apa alasannya?
a. kurangnya persaingan antara penduduk desa/kampung
b. kurangnya persaingan dengan penduduk desa tetangga
c. berkurangnya pembatasan dari pemerintah

H.3 Jika ketersediaan lahan hutan untuk dibuka BERKURANG, apa alasannya?
a. Persaingan antara penduduk desa/kampung
b. Persaingan dengan penduduk desa tetangga
c. Adanya pembatasan dari pemerintah

H.4 Selama 5 (lima) tahun terakhir, apakah hasil hutan yang dikonsumsi rumah tangga:
a. meningkat, karena
b. tidak berubah
c. berkurang, karena
d. tidak tahu

H.5 Selama 5 (lima) tahun terakhir, apakah pendapatan rumah tangga dari hasil hutan (yang dijual):
a. meningkat, karena
b. tidak berubah
c. berkurang, karena
d. tidak tahu

H.6 Bagaimana Bapak menggambarkan kehidupan keluarga dibandingkan 5 (lima) tahun yang lalu?
a. lebih baik, karena
b. tidak berubah
c. lebih susah, karena 
I. Persepsi tentang ketersediaan hutan antargenerasi

\begin{tabular}{lllll}
\hline Nama Jenis Kelamin Umur & Generasi & \\
\cline { 3 - 4 } & & Kakek/nenek Diri sendiri Anak/Cucu \\
\hline
\end{tabular}

J. Pendapatan di luar pertanian

J.1 Kegiatan apa yang merupakan kegiatan pokok?

$\square$ Pertanian $\square$ Perkebunan $\square$ Peternakan

$\square$ Melaut/Nelayan $\square$ Kehutanan $\square$ Lain

J.2 Apakah masih ada pendapatan dari luar pertanian, perkebunan, peternakan, perikanan dan hutan?

$\square$ Ya $\square$ Tidak (AKHIR KUESIONER)

J.3 Apa jenis pekerjaan tersebut?

J.4 Apakah pekerjaan tersebut bersifat $\square$ tetap $\square$ musiman

J.5 Kalau hasil dari kerja tersebut di atas dibandingkan dengan hasil kegiatan pokok, $\square$ lebih besar $\square$ sama $\square$ lebih kecil

J.6 Berapa besar pendapatan dari kegiatan tersebut di atas dalam setahun? Rp

K Kepemilikan aset

K.1 Gunakan pengamatan untuk mengetahui aset yang dimiliki

\begin{tabular}{|c|c|c|c|c|}
\hline Nama Barang & Jumlah & Tahun beli & Harga (Rp) & Keterangan \\
\hline \multicolumn{5}{|l|}{ Generator listrik } \\
\hline \multicolumn{5}{|l|}{ Lampu petromak } \\
\hline \multicolumn{5}{|l|}{ Televisi parabola } \\
\hline \multicolumn{5}{|l|}{ Radio tape } \\
\hline \multicolumn{5}{|l|}{ Chainsaw } \\
\hline \multicolumn{5}{|l|}{ Kulkas } \\
\hline \multicolumn{5}{|l|}{ Sepeda } \\
\hline \multicolumn{5}{|l|}{ Sepeda motor } \\
\hline $\begin{array}{l}\text { Motor ketinting/ } \\
\text { tempel }\end{array}$ & & & & \\
\hline
\end{tabular}


K.1 Lanjutan

\begin{tabular}{|c|c|c|c|c|}
\hline Nama Barang & Jumlah & Tahun beli & Harga (Rp) & Keterangan \\
\hline \multicolumn{5}{|l|}{ Perahu dayung } \\
\hline \multicolumn{5}{|l|}{ Mesin jahit } \\
\hline \multicolumn{5}{|l|}{ Tempayan, guci } \\
\hline \multicolumn{5}{|l|}{ Kamera } \\
\hline \multicolumn{5}{|l|}{ Senapan } \\
\hline Mesin ketam padi & & & & \\
\hline
\end{tabular}

K.2 Halaman kontrol

\begin{tabular}{l}
\hline Pengeluaran Rumah Tangga \\
\hline Biasa (Sehari-hari) \\
\hline Makanan/minuman \\
Energi (listrik, kayu, gas, minyak) \\
Transportasi (termasuk bensin) \\
Kebersihan (sabun, sabun cuci, ...........) \\
Baju/sepatu \\
Sekolah \\
Kesehatan \\
Pengembalian pinjaman \\
Rokok \\
Sumbangan (rutin) \\
Lainnya .......... \\
Total
\end{tabular}

Pengeluaran tak terduga (investasi atau lain-lain)

Rumah

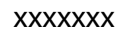

Transportasi (motor, mobil

$x x x x x x$

Tanah

$x x x x x x$

Ternak

$x x x x x x x$

Chainsaw

$x x x x x x x$

Alat-alat lain

$\operatorname{xxxxxxx}$

Emas

$x x x x x x$

Bantuan non rutin (keluarga, gereja dsb)

$\operatorname{xxxxxxx}$

Kesehatan

Lainnya

$\operatorname{xxxxxxx}$

Total

$x x x x x x x$ 
K.2 Lanjutan

\begin{tabular}{|c|c|c|c|}
\hline Pengeluaran Rumah Tangga & Sebulan & Setahun & Jumlah \\
\hline \multicolumn{4}{|c|}{ Pendapatan dari penjualan tak terduga atau dari pinjaman tahun lalu } \\
\hline Kendaraan bermotor & $\operatorname{xxxxxxx}$ & & \\
\hline Tanah & $x x x x x x x$ & & \\
\hline Ternak & $\operatorname{xxxxxxx}$ & & \\
\hline Chainsaw & $x x x x x x x$ & & \\
\hline Alat-alat lain & $\operatorname{xxxxxxx}$ & & \\
\hline Pinjaman & $x x x x x x x$ & & \\
\hline Bantuan dari keluarga & $\operatorname{xxxxxxx}$ & & \\
\hline Jual emas & $x x x x x x x$ & & \\
\hline Lainnya ............ & $x x x x x x x$ & & \\
\hline Total & $\operatorname{xxxxxxx}$ & & \\
\hline
\end{tabular}

Pendapatan dari menyewakan

Kerbau/kuda

Sepeda motor/mobil

Chainsaw

Rumah/kamar

Lain ...........

Total

Total

Ucapkan terimakasih kepada responden atas partisipasi dan untuk berbagi pengalaman, pikiran dan waktu 


\section{Kuesioner 3. Diskusi Kelompok Terfokus (FGD)}

(Kelompok: jender, kelompok umur, suku, dan mata pencaharian)

\begin{tabular}{|c|c|}
\hline \multicolumn{2}{|l|}{ Propinsi } \\
\hline & \\
\hline Kecamatan & \\
\hline Desa & \\
\hline Kelompok & - \\
\hline Peserta FGD & ................ \\
\hline
\end{tabular}

Tanggal/Waktu :

Fasilitator

Pencatat

\section{A. Hak atas sumberdaya hutan, penegakan dan kepatuhan}

1. Apa yang Anda ketahui tentang istilah hak atas tanah atau hak-hak atas sumberdaya hutan?

a. Apakah Anda mengetahui aturan (adat dan negara) yang memengaruhi hak Anda atas lahan atau sumberdaya hutan? Sebutkan dan jelaskan! Bagaimana Anda memahami peraturan tersebut?

b. Siapa pemilik hutan berdasarkan aturan hukum? Apakah masyarakat memiliki hak atau sertifikat?

2. Apa pandangan Anda tentang hutan berikut ini. Tolong jelaskan alasan pemilihan pandangan Anda dan bagaimana pandangan Anda memengaruhi penggunaan hutan?:

a. Hutan sebagai tempat keramat/suci?

b. Hutan sebagai sumberdaya ekonomi?

c. Hutan sebagai tempat suci dan sumberdaya ekonomi?

d. Hutan dengan fungsi lainnya?

3. Bagaimana Anda memanfaatkan lahan dan sumberdaya hutan?

Apa produk utama yang Anda peroleh dari hutan? Coba urutkan berdasarkan urutan kepentingannya. (Sebutkan 3 jenis untuk subsisten dan 3 jenis untuk dijual) 
Apakah mereka mendapatkan hasil tersebut berdasarkan musim atau diperoleh sepanjang tahun?

4. Apakah manfaat lain dari hutan yang berhubungan dengan kegiatan pengelolaan hutan atau kehutanan masyarakat?

Bagaimana manfaat hutan yang berhubungan dengan lapangan pekerjaan atau pendapatan dibagikan di antara masyarakat?

Apakah Anda puas dengan pembagian tersebut? Jika tidak, mengapa? Tolong beri contoh.

Bagaimana pembagian keuntungan antara pengguna hutan dapat diperbaiki? Harap berikan peringkat dari semua saran Anda.

5. Atribut/ciri apa yang harus dimiliki penduduk setempat agar bisa masuk ke hutan untuk keperluan rekreasi, agama atau kegiatan nonkonsumtif lainnya? (Contoh atribut/ciri: marga/suku tertentu, agama tertentu, laki-laki, perempuan, tua, muda)

\section{B. Pengelolaan hutan}

6. Menurut Anda, berapa banyak (ukuran lokal) kebutuhan Anda diambil dari hutan? Misalnya, untuk makanan ternak, kayu bakar, kayu perumahan, makanan, atau untuk kebutuhan lain dll. (Untuk 3 produk subsisten dan 3 produk dijual)

Apakah kebutuhan ini meningkat atau menurun dalam 5-10 tahun terakhir? Jelaskan alasan penurunan atau peningkatan dan berikan peringkat berdasarkan urutan kepentingan (Gunakan Tabel berikut untuk membuat daftar hasil hutan yang digunakan, prioritaskan 3 jenis subsisten dan 3 jenis untuk dijual, tumbuhan dan binatang)

\begin{tabular}{llll}
\hline Hasil Hutan & 2000 & 2005 & 2010
\end{tabular}


7. Apa bentuk tanggung jawab Anda terhadap hutan (sehubungan dengan fungsi pengelolaan dan konservasi hutan)? Gunakan Tabel berikut untuk menjelaskan:

\section{Fungsi Manajemen}

Aktor yang seharusnya terlibat (internal dan eksternal)

Menetapkan/melindungi batas-

batas (SDA)

Mengembangkan/menerapkan

aturan/peraturan

Memantau kepatuhan

Menyelesaikan konflik

Memberikan kepemimpinan/

organisasi

Menilai denda/sanksi

Contoh: Jika pengguna hutan diminta untuk memperbaiki kondisi hutan dengan melakukan kegiatan regenerasi atau kegiatan lain (misalnya, membasmi perambahan oleh jenis invasif, membuat pembibitan untuk mendistribusikan bibit, mengurangi tingkat panen, atau menanam modal dalam teknologi untuk perbaikan hutan, misalnya peternakan lebah madu, menanam pohon, atau metode lain untuk melindungi, menjaga atau meningkatkan sumberdaya hutan.

a. Jika pernah, sebutkan. Seberapa sering Anda melakukan kegiatan yang disebutkan di atas selama tahun lalu?

b. Apakah ada anggota masyarakat tertentu yang mencoba membatasi pemanfaatan hutan dengan pemanenan hasil hutan dari lahan komunal lain atau hutan milik pemerintah?

c. Jika ya, di hutan mana yang telah digunakan secara intensif sehingga membatasi penggunaan hutan di desa ini? (misalnya, hutan milik swasta, hutan pemerintah, hutan komunal kelompok lain yang memiliki hak atas hutan).

d. Apakah ada pembatasan pemanenan hasil hutan selama 5 tahun terakhir? Jika ya, bagaimana perubahannya? Apa yang menjadi dasar pembatasan tersebut. 
e. Menurut Anda, apakah orang di desa mengikuti aturan untuk pemanenan, pengolahan, atau penjualan produk dari hutan atau menggunakan hutan untuk tujuan nonkonsumtif. Tolong jelaskan jawaban Anda.

- Tidak pernah atau jarang

- Kadang-kadang

- Sering

- Hampir selalu mengikuti

Jelaskan jawaban Anda.

f. Menurut Anda, apa saja masalah paling serius dalam mengelola hutan untuk lima tahun ke depan. Bagaimana cara memecahkannya?

g. Menurut Anda, apa kesempatan dan peluang yang mungkin terjadi dalam 5 (lima) tahun ke depan yang terkait dengan pengelolaan hutan? Bagaimana merealisasikan peluang tersebut, apa yang perlu dilakukan? Siapa yang perlu dilibatkan?

\section{Persepsi mengenai kepastian lahan}

8. Apakah menurut Anda, Anda akan terus memiliki akses ke lahan dan sumberdaya hutan selama 5 tahun ke depan?

a. Jelaskan bagaimana perasaan Anda dan apa yang menyebabkan munculnya perasaan tersebut?

b. Jika persepsinya negatif: Apa yang harus dilakukan agar ketakutan/ keraguan tersebut dipulihkan? Apa tindakan yang dapat diambil untuk membuat hak Anda atas tanah dan hutan lebih aman? Dengan siapa? Apa yang menjadi tanggung jawab (desa Anda)?

9. Apakah kerapatan pepohonan di hutan berubah dalam lima tahun terakhir? Jika ya, sebutkan 3 alasan yang terpenting bagi perubahan kepadatan pohon.

10. Selama 5 (lima) tahun terakhir, adakah perubahan di daerah di mana terdapat vegetasi di dalam hutan? Jika meningkat, sebutkan 3 alasan kenapa meningkat. Jika menurun, sebutkan 3 alasan kenapa menurun. 


\section{Proyek pembangunan di desa}

11. Sebutkan proyek pembangunan yang telah dilakukan di desa ini dalam 10 (sepuluh) tahun terakhir untuk meningkatkan partisipasi masyarakat?

a. Pernahkah ada proyek tentang akses/hak atas hutan dan lahan dan pengelolaannya? (termasuk perubahan iklim, tanaman obat, dll)

b. Apakah ada proyek-proyek khusus yang mendorong hak-hak dan kepemilikan masyarakat?

c. Apakah ada proyek-proyek tertentu yang turut mendorong partisipasi perempuan dan laki-laki dalam pengelolaan hutan? Jelaskan proyekproyek tersebut:

- Nama;

- Sponsor (LSM/Pemerintah/Donor);

- Tujuan dan kegiatan kunci;

- Periode kegiatan

Lihat catatan untuk menentukan tingkat partisipasi masyarakat dalam masing-masing proyek.

12. Bagaimana tingkat kesuksesan proyek tersebut? Tolong jelaskan mengenai peringkat pilihan Anda. Jika gagal, sebutkan 3 cara yang bisa dilakukan untuk memperbaiki kegagalan tersebut.
a. Sukses,
b. Sedikit sukses,
c. Biasa
d. Agak tidak berhasil,
e. Gagal

Jelaskan siapa yang mengatakan hal itu. Jika proyek gagal, jelaskan 3 cara bagaimana kegagalan tersebut bisa dihindari. 
Laporan hasil FGD

Tanggal: $\quad$ Fasilitator:

Waktu: Pencatat:

Desa:

Peserta diskusi:

Catatan hasil diskusi:

Topik yang menguras energi

Bagaimana konsensus dicapai (sulit/ mudah)? Jelaskan

Tuliskan petikan pendapat yang menarik

Apakah ada temuan yang khusus dan tak terduga

Diskusi yang spontan dan relevan saat istirahat atau setelah diskusi telah ditutup 


\section{Kuesioner 4. Wawancara mendalam dengan informan kunci}

(Kepala desa, kepala adat, wakil masyarakat, kepala marga)

\begin{tabular}{|c|c|}
\hline Propinsi & \\
\hline Kabupaten & \\
\hline Kecamatan & \\
\hline Desa & \\
\hline Nama Informan/ & \\
\hline Umur/Suku/Marga & \\
\hline
\end{tabular}

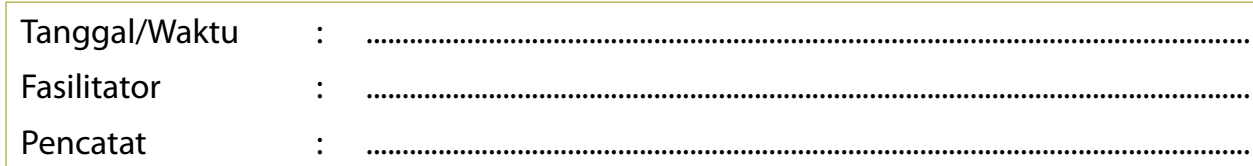

\section{A. Kelembagaan yang terkait pengaturan hutan}

1. Apakah di desa ini ada aturan resmi dan atau aturan tidak resmi I (termasuk norma adat, mitos, tradisi) - yang terkait dengan penggunaan atau masuk ke hutan (pertimbangkan juga dunia roh, yang mendasari tradisi yang membolehkan (atau melarang) akses ke hutan).

Apakah aturan ini diterapkan secara berbeda untuk laki-laki dan perempuan? Tolong jelaskan.

2. Apakah ada aturan khusus yang membatasi kegiatan yang dilakukan di hutan seperti tersebut di bawah ini?

a. Pemeliharaan/rehabilitasi (misalnya, membasmi jenis invasif; meningkatkan regenerasi, membuat pembatas untuk mencegah ternak berkeliaran ke hutan dll). Jika ada, jelaskan. Siapakah yang membuat aturan ini(desa atau pemerintah daerah)?

b. Pemanenan hasil hutan (misalnya, produk apa yang harus dipanen, waktu panen, kuantitas/tahun?). Jika ada, jelaskan. Siapakah yang membuat aturan ini(desa atau pemerintah daerah)? 
c. Apakah ada aturan yang membatasi kegiatan lainnya? (misalnya, pengolahan hasil hutan, penjualan hasil hutan? Jika ada, harap jelaskan. Siapakah yang membuat aturan ini (desa atau pemerintah daerah)? Apakah produk yang diolah itu untuk konsumsi sendiri atau dijual?

3. Sanksi hukuman apa yang diberikan kepada anggota masyarakat desa, jika mereka melanggar aturan-aturan yang terkait dengan hutan.

a. Melanggar satu kali?

b. Melanggar dua kali?

c. Melanggar berkali-kali/sering?

Siapa yang memutuskan untuk memberikan hukuman tersebut?

4. a. Siapa yang bertanggung jawab di desa ini untuk membuat aturan tentang hutan? Siapakah mereka? Bagaimana Anda menggambarkan mereka?

b. Bagaimana Anda menggambarkan individu-individu yang tidak membuat aturan? Apakah individu-individu tersebut berasal dari satu kelompok agama, satu kelompok suku, kelompok laki-laki atau perempuan?

5. Apabila aturan adat/desa ditegakkan, sejauh mana sanksinya ditaati oleh anggota masyarakat?

a. Tidak satupun anggota masyarakat mematuhi sanksi

b. Beberapa anggota masyarakat mematuhi sanksi

c. Hampir setengah anggota masyarakat (50\%) mematuhi sanksi

d. Lebih dari sebagian besar anggota masyarakat mematuhi sanksi

e. Seluruh anggota masyarakat mematuhi sanksi

6. Jika anggota masyarakat yang menggunakan hutan kehilangan hak untuk memanen/mengambil hasil hutan tertentu, bagaimana hak mereka bisa dikembalikan? 
7. Selama lima tahun terakhir, apakah ada pihak luar (aparat pemerintah) yang pernah diminta untuk memberikan sanksi hukuman terhadap anggota masyarakat yang melanggar? Jika pernah, jelaskan peristiwa tersebut?

\section{B. Ancaman dan konflik}

8. Jelaskan siapa saja yang memanfaatkan hutan di wilayah desa ini?

a. Masyarakat desa, marga tertentu, suku tertentu, masyarakat desa lain?

b. Siapa mereka dan darimana mereka datang?

c. Seberapa sering mereka menggunakan hutan di wilayah ini?

d. Bagian hutan mana yang mereka gunakan dan untuk apa?

e. Apakah mereka perlu izin untuk menggunakan hutan? Siapa yang memberikan ijin kepada mereka untuk menggunakan hutan? (Kepala desa? Kepala Adat? Camat?)

9. Jika masyarakat yang menggunakan hutan di wilayah ini berasal dari marga atau suku yang berbeda, apakah mereka memahami dengan baik semua aturan yang berlaku? Apakah mereka mengikuti aturan tersebut?

10. Apakah ada konflik sehubungan dengan penggunaan lahan dan hutan antar amarga atau suku di desa ini selama lima tahun terakhir?

a. Jika ada, jelaskan asal usul konflik dan bagaimana konflik tersebut dapat diselesaikan?

b. Berapa lama waktu yang dibutuhkan untuk menyelesaikan konflik?

c. Apa tantangan yang Anda hadapi ketika mencoba untuk menyelesaikan konflik?

11. Apakah ada perbedaan pendapat atau konflik atas akses hutan atau alokasi lahan dengan pihak lain di luar desa ini selama lima tahun terakhir? 
a. Jika ya, siapakah mereka? (misalnya, LSM, dinas, departemen, kementerian, atau pihak lain?)

b. Kapan konflik tersebut mulai dan kapan berakhir?

c. Apa alasan yang mendasari terjadinya konflik?

d. Bagaimana Anda menyelesaikan konflik tersebut?

e. Siapakah pihak yang terlibat dalam menyelesaikan konflik?

f. Apa yang mereka lakukan untuk menyelesaikan konflik?

g. Apakah ada orang yang dominan dalam menyelesaikan konflik? Siapa mereka dan bagaimana mereka melakukannya?

h. Apakah Anda puas dengan penyelesaian konflik tersebut? Jika tidak, apa yang Anda lakukan untuk mengatasi ketidakpuasan Anda? Apakah Anda berhasil? Apa saja kendala utama yang Anda hadapi saat menyelesaikan konflik?

12. Selama lima tahun terakhir, apakah pernah timbul masalah yang menyebabkan konflik atas akses ke hutan atau alokasi lahan di antara masyarakat sendiri?

a. Jika ya, jelaskan konflik tersebut?

b. Bagaimana konflik internal di desa ini dapat diselesaikan?

c. Apakah ada cara atau mekanisme untuk menyelesaikan konflik ini?

d. Apa hambatan utama untuk menyelesaikan konflik di desa ini? 
e. Apakah ada hal-hal lain yang dapat membantu untuk mengelola konflik dan bagaimana menyelesaikan konflik secara internal?

13. Selama lima tahun terakhir, bagaimana pendapat Anda mengenai tingkat konflik di dalam kelompok telah (mohon jelaskan):
a. Meningkat
b. Sama saja
c. Menurun
d. Mengganggu kegiatan sehari-hari
e. Mengganggu sewaktu-waktu
f. Disalurkan dengan cara-cara yang tidak mengganggu kegiatan
sehari-hari

14. Bagaimana masyarakat menyatakan keinginan dan keprihatinan mereka tentang lahan dan hutan kepada pihak berwenang? (misalnya, pejabat lokal, pejabat pemerintah, dll)? jawaban boleh lebih dari satu:
a. Petisi resmi
b. Dengar pendapat resmi
c. Demonstrasi
d. Pertemuan Umum
e. Penyanderaan pejabat untuk ditukarkan (cara ilegal)
f. Lainnya (jelaskan)

15. Apabila Anda menggunakan salah satu cara di atas, jelaskan cara tersebut diterapkan untuk kasus apa?

Apa keinginan/permintaan masyarakat?

Apakah pemerintah bisa mengatasi masalah tersebut? Jika tidak, mengapa tidak? Jika ya, apakah Anda puas dengan solusi mereka? 


\section{Catatan 9 - Pengalaman dari proyek CoLUPSIA}

Proyek CoLUPSIA adalah proyek penelitian yang didanai oleh Uni Eropa. Proyek ini dilaksanakan oleh CIRAD (Centre de coopération internationale en recherche agronomique pour le développement) melalui kolaborasi dengan mitra lembaga penelitian yaitu CIFOR (Center for International Forestry Research), Universitas Pattimura di Ambon, Universitas Gadjah Mada di Yogyakarta dan LSM (Telapak, HuMA, TOMA dan Riak Bumi).

Salah satu komponen utama CoLUPSIA adalah melengkapi survei sosial-ekonomi (survei rumah tangga dan profil desa), bersamaan dengan diskusi kelompok terfokus dan wawancara informan kunci, di desa-desa di Kapuas Hulu di Provinsi Kalimantan Barat dan Maluku Tengah (Pulau Seram) di Provinsi Maluku. Berikut ini adalah gambaran hasil dan fakta yang penting.

- Sampel desa dipilih dari wilayah percontohan: empat di Kapuas Hulu dan lima di Maluku Tengah. Wawancara dilakukan di wilayah sampel di masing-masing kabupaten, sebagaimana ditunjukkan pada Gambar 2 dan 3.

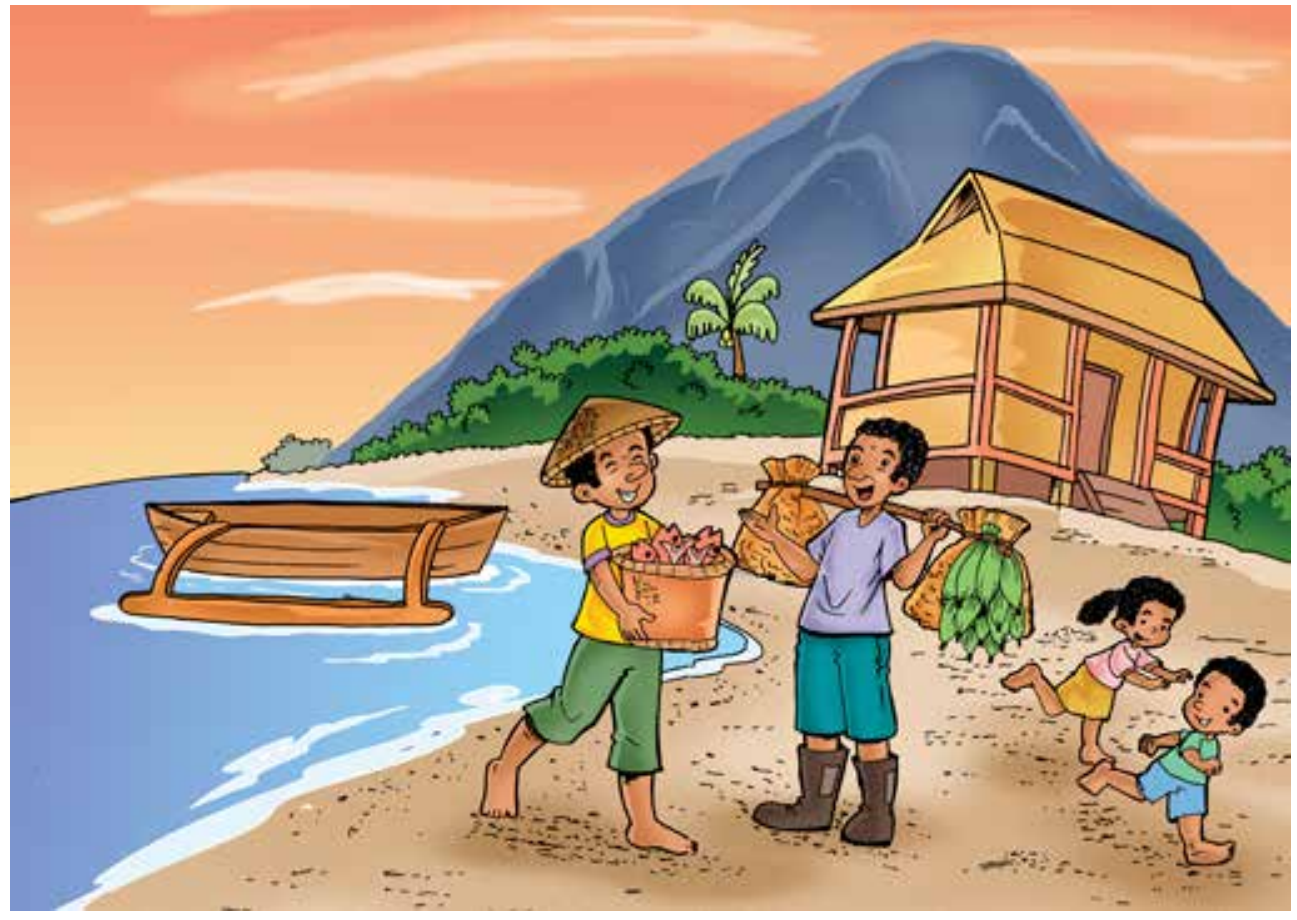


- Selama 2010 dan 2011, 566 rumah tangga diwawancarai di Maluku Tengah dan 800 di Kapuas Hulu.

- Survei telah dilakukan di tingkat desa dengan jumlah total 39 desa (20 di Kapuas Hulu dan 19 di Maluku Tengah).

- Survei seratus informan kunci telah diselesaikan (40 di Kapuas Hulu dan 60 di Maluku Tengah).

- Data telah dikoleksi, dibersihkan dan dianalisis menggunakan SPSS, Excel dan nVivo (perangkat lunak untuk analisis data kualitatif).

Informasi yang dikumpulkan digunakan untuk menghasilkan dua laporan yang merangkum penemuan di masing-masing kabupaten. Kedua laporan tersebut tersedia dalam dokumen terpisah.

Hasil survei akan digunakan sebagai data dasar untuk perencanaan penggunaan lahan, dan juga untuk menekankan pada isu-isu yang relevan - kendala dan peluang - dalam menghadapi masyarakat terkait dengan penggunaan lahan dan mekanisme yang potensial untuk mengatasi masalah yang ada. Data dasar sosial-ekonomi yang kuat ini dapat dikombinasikan dengan data biofisik untuk memberikan suatu pandangan langsung tentang situasi dalam wilayah studi.

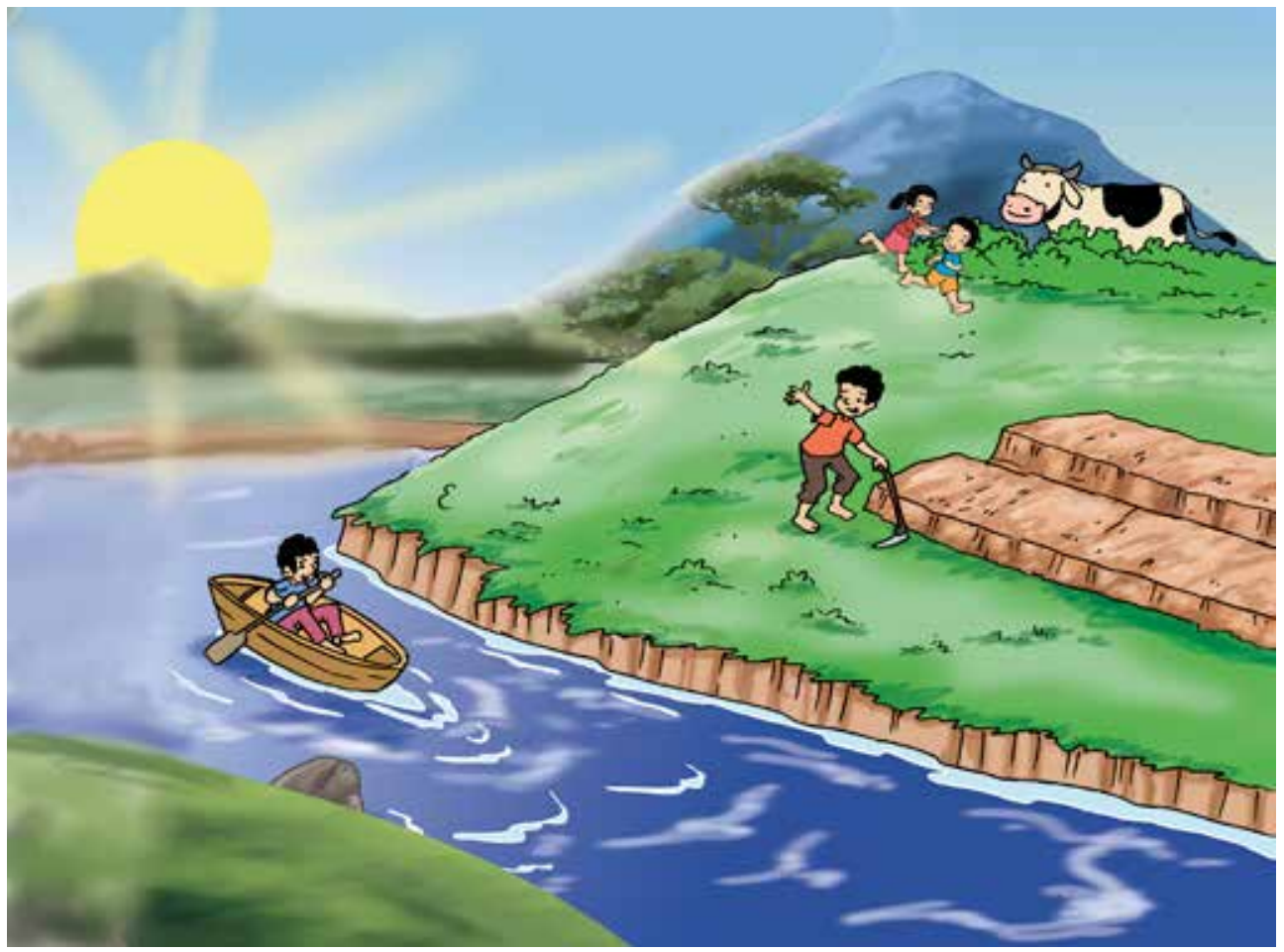


Memahami masyarakat dan hubungan internal dan eksternal mereka (misalnya, badan pemerintah) memberikan landasan yang baik untuk proses pengembangan yang melibatkan masyarakat dalam pelaksanaan pembuatan keputusan tentang perencanaan penggunaan lahan secara kolaboratif.

Pengalaman dari CoLUPSIA menawarkan beberapa pelajaran umum yang dapat digunakan untuk mereka yang melakukan survei sosial-ekonomi serupa di masa depan.

- Waktu survei adalah penting. Melaksanakan survei selama musim tanam mungkin akan bermasalah karena penduduk desa sangat sibuk. Untuk mengatasi hal seperti ini, tim CoLUPSIA secara sopan bisa mengundang penduduk untuk mengambil bagian dalam wawancara singkat di malam hari dan, dimana diperlukan, dilanjutkan wawancaranya di pagi hari. Sebagai alternatif, wawancara dapat dijadualkan setelah penduduk tiba di rumah dari kebun mereka. Juga sangat sulit untuk mengumpulkan orang dan melakukan diskusi kelompok selama musim tanam. Masalah serupa juga muncul jika mengunjungi desa selama musim panen, saat desa sedang melakukan selamatan/perayaan.

- Insentif sebagai kompensasi. Dalam kondisi tertentu, bagi mereka yang berpartisipasi dalam pekerjaan survei mungkin berharap untuk menerima suatu insentif (misalnya, uang) dari proyek. Karena itu, sejak awal survei sangat penting untuk dijelaskan kepada masyarakat mengenai ada atau tidak adanya insentif.

- Dalam merencanakan proses wawancara, penting sekali mempertimbangkan waktu yang tersedia dan teknik yang paling tepat saat mengajukan pertanyaan. Menjaga minat mereka yang diwawancarai merupakan tantangan, terutama jika survei sangat panjang. Dua jam adalah waktu maksimum untuk wawancara, tetapi jika responden yang diwawancarai kehilangan minat, maka kegiatan survei akan selesai lebih cepat. Gunakan istilah yang sederhana dan jelas, sebaiknya dalam dialek atau bahasa lokal, ketika mengajukan pertanyaan.

- Memeriksa informasi yang dikumpulkan. Pemimpin tim bersama anggotanya harus memeriksa semua data dengan lengkap sebelum meninggalkan desa. Ini akan menghindari masalah yang sering timbul, karena informasi yang dicatat tidak lengkap hanya setelah tim meninggalkan desa dan dalam beberapa kasus ketika telah kembali ke kantor mereka.

\section{Metodologi yang digunakan oleh tim CoLUPSIA}

Tujuan umum penelitian ini adalah untuk memahami faktor sosial-ekonomi yang memengaruhi pola penggunaan sumberdaya alam di tingkat kabupaten. Proyek ini bekerja sama dengan universitas lokal dan LSM. Survei telah selesai dilakukan 


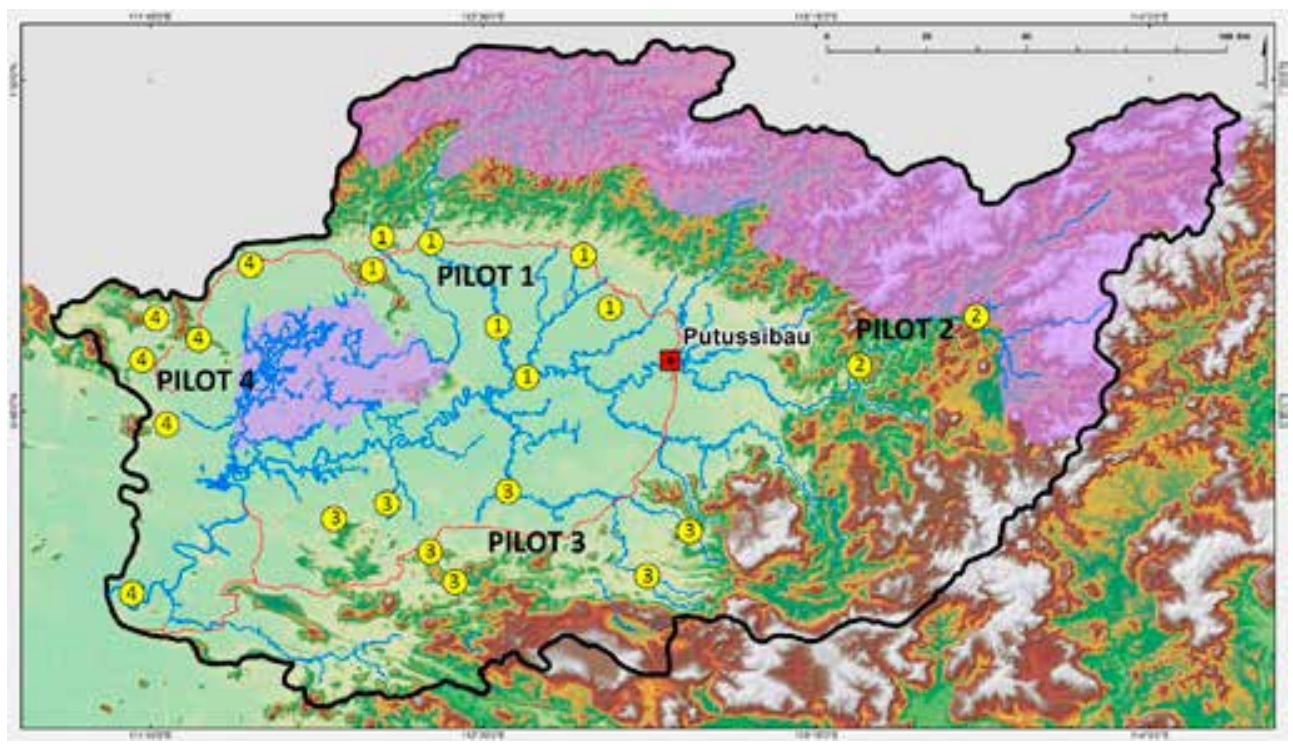

Gambar 2. Desa-desa penelitian di empat lokasi pilot di Kapuas Hulu, Kalimantan Barat

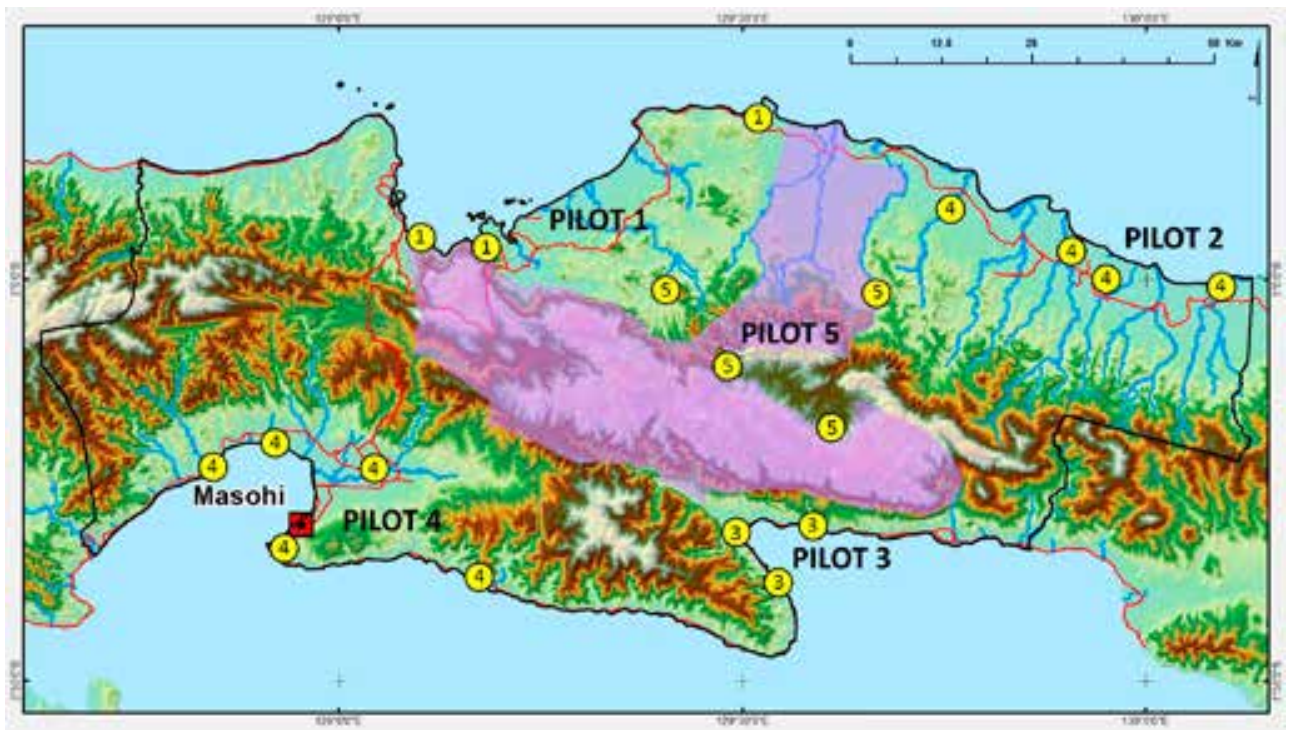

Gambar 3. Desa-desa penelitian di lima lokasi pilot di Maluku Tengah (Pulau Seram), Maluku 
di 19 desa dan 30 rumah tangga per desa di Maluku Tengah, dan 20 desa dan 40 rumah tangga per desa di Kabupaten Kapuas Hulu. Rumah tangga dipilih secara acak menggunakan metode pengambilan sampel acak sistematis. Proyek ini mengumpulkan data melalui survei rumah tangga, diskusi kelompok dan wawancara informan kunci.

Survei ini menggunakan dua kuesioner: kuesioner desa dan rumah tangga. Kuesioner desa digunakan untuk informan kunci, seperti kepala desa dan tokoh adat untuk mendapatkan informasi menyeluruh tentang desa mereka dan isu-isu yang terkait dengan pengelolaan hutan, sejarah konflik dan sudut pandang lokal mengenai pemanfaatan sumberdaya alam. Kuesioner rumah tangga digunakan untuk wawancara dalam rangka mengumpulkan informasi tentang demografi, kegiatan ekonomi dan persepsi tentang jaminan kepemilikan dan penggunaan sumberdaya.

Diskusi kelompok terfokus dilakukan untuk membahas isu-isu tentang kepemilikan lahan. Pemilihan kelompok dilakukan berdasarkan jenis kelamin, usia dan keragaman komposisi etnis/suku. Panduan untuk melakukan diskusi kelompok disusun, yaitu meliputi hak milik, jaminan kepemilikan, pengelolaan hutan, konflik/ancaman dan persepsi masyarakat tentang sumberdaya mereka.

\section{Kebutuhan informasi}

Sebagaimana diuraikan dalam panduan sosial-ekonomi, suatu survei harus didesain sedemikian rupa untuk memastikan bahwa informasi yang dikumpulkan dapat memenuhi tujuan umum survei. Misalnya, jika surveinya tentang penggunaan lahan, maka pertanyaan-pertanyaan yang dibuat harus mencerminkan tujuan ini. Survei tidak harus bertujuan untuk mengumpulkan semua informasi sosialekonomi yang memungkinkan, melainkan harus ditargetkan untuk tujuan survei yang lebih spesifik. Ini akan menjamin bahwa hasil survei sesuai target dan surveinya dapat dilakukan dalam jangka waktu yang wajar. Tabel 5 memberikan beberapa contoh jenis data yang dapat dikumpulkan dan sarana yang paling tepat untuk mengumpulkan informasi yang digunakan dalam perencanaan penggunaan lahan kolaboratif. 
Tabel 5. Data sosial-ekonomi yang dibutuhkan untuk kolaboratif perencanaan penggunaan lahan

Informasi Bahan dan metoda

- Demografi (umur, jender, komposisi rumah tangga, pendidikan)

- Pertanian (sekarang dan masa lalu); hewan ternak dan perikanan; dan

- Kuesioner masalah terkait pertanian

- Layanan penyuluhan

- Hasil hutan

- Pola mata pencaharian (sumber pendapatan, aset, biaya produksi, biaya rumah tangga)

- Persepsi 'perubahan'dan ketersediaan hutan

- Sumberdaya alam dan penggunaan lahan (total wilayah setiap jenis pola penggunaan lahan, status lahan, produk pertanian, produk kebun, ternak, ikan, koleksi hasil hutan (kayu dan non-kayu), persepsi tentang hutan, persepsi tentang status lahan, dan kendala)

- Sumber pendapatan dari nonpertanian

- Aset rumah tangga

- Aspek kelembagaan (keanggotaan organisasi, layanan penyuluhan)

- Profil desa

- Infrastruktur

- Situasi perekonomian desa

- Survei rumah tangga (30 rumah tangga)

- Program pembangunan

- Masalah khusus degan desa dan/ atau hutan

- Hutan yang berhubungan dengan pengaturan kelembagaan (jenis lembaga, peraturan, denda)

- Ancaman dan konflik (termasuk caracara untuk menyelesaikan konflik)

- Hak atas sumberdaya hutan, - Kuesioner

- Wawancara dengan kepala desa, kepala adat, dan kepala suku atau marga penegakan dan kepatuhan

- Diskusi kelompok terfokus (kelompok dibagi berdasarkan umur dan jender)

- Pengelolaan hutan

- Wawancara informan kunci

- Persepsi tentang kepemilikan lahan

- Proyek pembangunan desa 


\section{Rujukan}

Abdrabo, M.A. dan M.A. Hassaan 2003. From river catchments areas to the sea: comparative and integrated approach to the ecology of Mediterranean coastal zones for sustainable management (MEDCORE). A manual for socioeconomic study. Centre for Environment and Development for the Arab Region and Europe (CEDARE).

Colfer, C.J.P., M.A. Brocklesby, C. Diaw, P. Etuge, M. Günter, E. Harwell, C. McDougall, N.M. Porro, R. Porro dan R. Prabhu 1999. The BAG: basic assessment guide for human well-being. The criteria $\&$ indicator toolbox series No. 5. CIFOR, Bogor, Indonesia.

Dawson, S., dan L. Manderson 1993. A manual for the use of focus groups. Methods for social research in disease. International Nutrition Foundation for Developing Countries (INFDC), Boston, MA, USA.

De Brune dan R. Santoso 1998. Socio-economic for land use planning. FIMPBPKP Technical Series No. 11.

Food and Agriculture Organization of the United Nations (FAO) 2002. FAO land tenure studies 3: land tenure and rural development. FAO, Rome.

Glaser, B.G. dan A.L. Strauss 1967. The Discovery of Grounded Theory: Strategies for Qualitative Research, Chicago, Aldine Publishing Company

Leroy-Iskandar, C. dan R. Santoso 2002. Socio-economic for land use planning 1: general issues and methodologies. FIMP-BPKP Technical Series No. 20.

Liswanti, N. dan I. Basuki 2009. Guidelines for adapted Multidisciplinary Landscape Assessment methods for fire management project in India. CIFOR, Bogor, Indonesia.

Markelova, H. 2012. Report on the findings from the focus group discussion surveys and key informant interviews for the 'Collaborative land use planning and sustainable institutional arrangements for strengthening land tenure, forest, and community right in Indonesia. CoLUPSIA project. Bogor, Indonesia.

Mendenhall, W., R.J. Beaver dan B.M. Beaver 2003. Introduction to Probability and Statistics. $11^{\text {th }}$ Edisi, Brooks/Cole, USA.

NVivo 9 2010. NVivo qualitative data analysis software Version 9, 2010. QSR International Pty Ltd.

Roche, R. 2007. Livelihoods approaches as a conservation tool. IGERT Program. University of Rhode Island. Kingston, RI, USA. 
Shantiko, B., Y. Andries, B. Morialkosu dan D. Amarduan 2004. Socio economic analysis of rural Tanimbar. Tanimbar Land Use Planning Project. Technical Series No. 3. Jakarta.

Sheil, D. dan N. Liswanti 2006. Scoring the importance of tropical forest landscapes with local people: Patterns and insights. Environmental Management 38:126-136.

Sheil, D., R.K. Puri, I. Basuki, M. van Heist, M. Wan, N. Liswanti, Rukmiyati, M.A. Agung Sardjono, I. Samsoedin dan K. Sidiyasa 2003. Exploring biological diversity, environment and local people's perspectives in forest landscapes. Methods for a multidisciplinary landscape assessment. 2nd edition. CIFOR, Bogor, Indonesia.

Turell, G., C. Patterson, B. Oldenburg, T. Gould dan M.A. Roy 2003. The socio-economic patterning of survey participation and non-response error in multilevel study of food purchasing behavior: area and individual level characteristics. Public Health Nutrition 6:181-89.

Varkevisser, C., I. Pathmanathan dan A. Brownlee 2003. Designing and conducting health system research projects. Volume 1: proposal development and fieldwork. World Health Organization/International Development Research Centre. KIT Publishers, Amsterdam.

\section{Situs web}

Badan Pusat Statistik (BPS) (Indonesia’s Central Statistics Agency):

http://www.bps.go.id

CoLUPSIA: http://www.colupsia.org/. 

Publikasi ini memuat hasil penelitian pendahuluan, dan signifikan untuk isu-isu yang berkaitan dengan hutan tropis, yang perlu dipublikasikan secara tepat waktu. Publikasi ini diproduksi sebagai informasi dan promosi ajang diskusi. Isi publikasi ini telah diulas secara internal namun belum mengalami proses lebih lebih lanjut untuk diulas oleh pihak eksternal.

Alat survei sosial-ekonomi dirancang untuk mengumpulkan informasi sebagai sarana meningkatkan pemahaman tentang sistem pengelolaan sumberdaya lokal, penggunaan sumberdaya dan kepentingan relatif masing-masing untuk rumah tangga dan desa. Survei juga memberikan informasi tentang interaksi antara sistem pengambilan keputusan oleh pemerintah, tren persepsi masyarakat dan isu-isu prioritas, dan pengetahuan tentang lembaga berbasis masyarakat dan peran mereka dalam pemanfaatan berkelanjutan dan konservasi sumberdaya alam. Penggunaan survei merupakan langkah awal yang penting dalam melibatkan masyarakat lokal dan memastikan bahwa suara-suara lokal didengar dan bahwa hubungan masyarakat dengan sumber daya, akses dan hak atas lahan dimasukkan dalam proses perencanaan tata guna lahan kolaboratif.

Perencanaan penggunaan lahan kolaboratif melibatkan kerja sama dengan semua pemangku kepentingan pemerintah, masyarakat lokal, sektor swasta dan individu lain yang relevan - untuk memastikan bahwa lahan digunakan secara berkelanjutan, menghindari dampak negatif atau ancaman dari degradasi lingkungan dan hilangnya hutan sambil memastikan bahwa pertimbangan sosial dan ekonomi dari semua pengguna dipertimbangkan. Dalam kaitan khususnya dengan masyarakat, tujuan perencanaan penggunaan lahan kolaboratif adalah sebagai berikut:

Untuk memastikan bahwa keputusan perencanaan penggunaan lahan diambil dengan mempertimbangkan pendapat masyarakat lokal, kebutuhan penggunaan lahan dan kondisi sosial-ekonomi (peluang dan kendala), termasuk hak akses ke lahan dan untuk menggunakannya

Tujuan dari panduan ini (dan Catatan Pendukung) adalah untuk memberikan langkah-langkah praktis (desain survei, pengambilan sampel dan kebutuhan data; perencanaan dan pelatihan; melakukan survei) untuk para praktisi di lapangan dalam melakukan survei sosial ekonomi rumah tangga dan desa, termasuk diskusi kelompok terfokus dan wawancara informan kunci. Informasi yang diperoleh dapat digunakan secara langsung dalam proses perencanaan penggunaan lahan kolaboratif yang membantu untuk melancarkan atau memperkuat konsensus tentang kepemilikan lahan dan hak-hak di daerah, sekarang dan di masa depan.

Penelitian ini dilakukan sebagai bagian dari proyek perencanaan penggunaan lahan kolaboratif dan penataan kelembagaan yang berkelanjutan, didanai oleh Uni Eropa, dan dijalankan oleh CIRAD yang bermitra dengan CIFOR, TELAPAK dan beberapa LSM lokal dan universitas. Tujuan penelitian ini adalah memberikan kontribusi untuk menghindari degradasi lingkungan dan memperkuat hak kepemilikan lahan dan hak masyarakat dengan mengintegrasikan pandangan semua pemangku kepentingan dalam proses-proses perencanaan penggunaan lahan. Hasil yang diharapkan adalah adanya hubungan antara perencanaan tata guna lahan, alokasi lahan, dan penyediaan dan potensi pembayaran jasa ekosistem. Proyek ini fokus pada dua kabupaten yaitu Kapuas Hulu dan Maluku Tengah di Indonesia.

\section{cifor.org}

blog.cifor.org
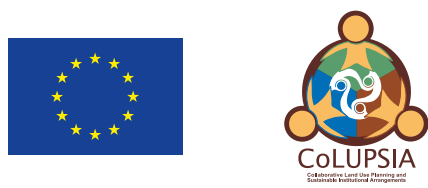

Center for International Forestry Research

CIFOR memajukan kesejahteraan manusia, konservasi lingkungan dan kesetaraan melalui penelitian yang berorientasi pada kebijakan dan praktik kehutanan di negara berkembang. CIFOR merupakan salah satu Pusat Penelitian Konsorsium CGIAR. CIFOR berkantor pusat di Bogor, Indonesia dengan kantor wilayah di Asia, Afrika dan Amerika Selatan.

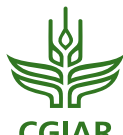

